Toxic Substances Hydrology Program

Prepared in cooperation with the

Air Force Center for Engineering and the Environment

\title{
Transport of Nitrogen in a Treated-Wastewater Plume to Coastal Discharge Areas, Ashumet Valley, Cape Cod, Massachusetts
}

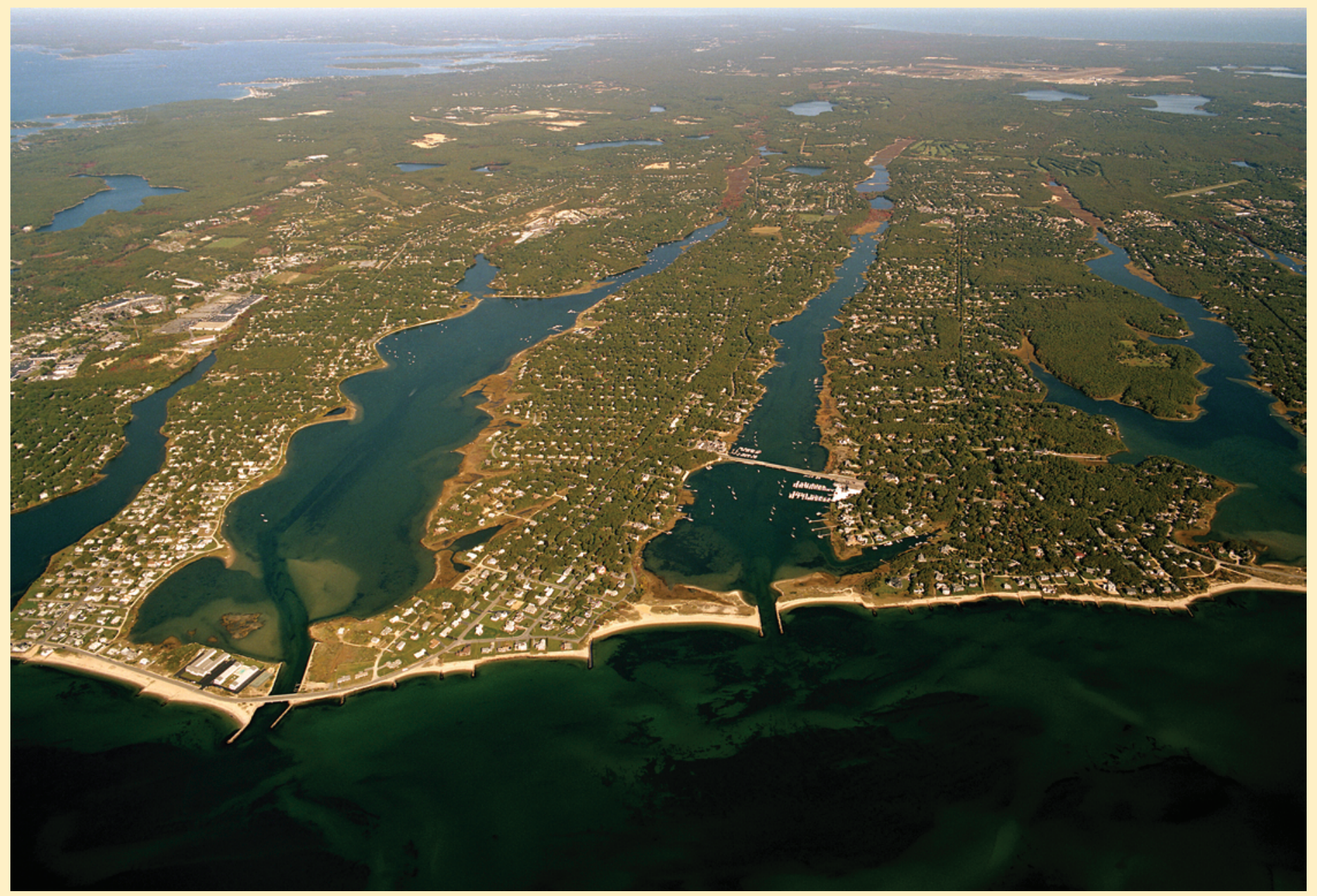

Scientific Investigations Report 2013-5061 


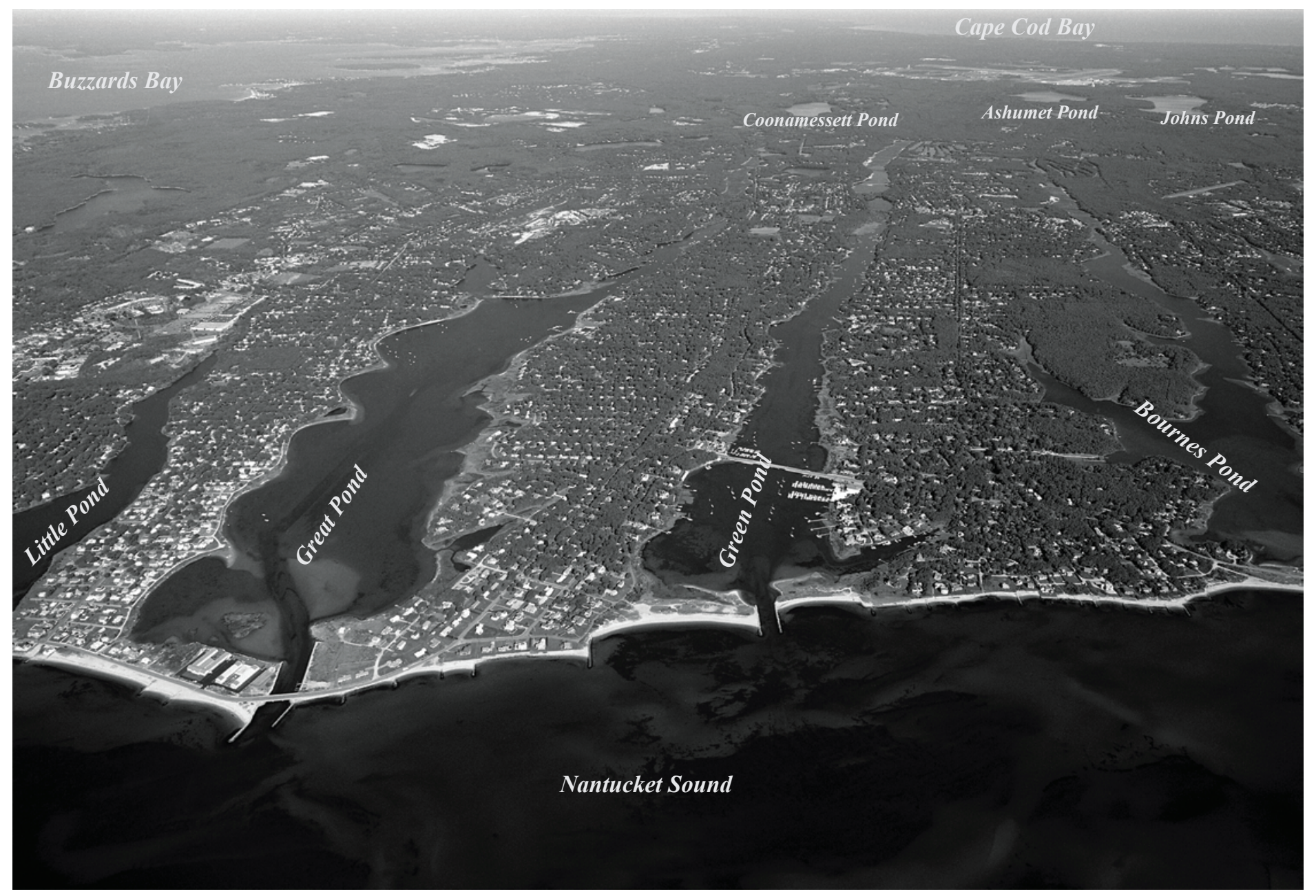

Cover photo. View northward from above Nantucket Sound of the narrow coastal saltwater embayments, referred to as coastal ponds, in southern Falmouth, Cape Cod, Massachusetts, and several freshwater ponds 2 to 4 miles inland from the coast. The Massachusetts Military Reservation is the tan area in the top right of the photo. Photography by Joseph R. Melanson, Aerials Only (http://www.skypic.com), used with permission. 


\section{Transport of Nitrogen in a Treated- Wastewater Plume to Coastal Discharge Areas, Ashumet Valley, Cape Cod, Massachusetts}

By Jeffrey R. Barbaro, Donald A. Walter, and Denis R. LeBlanc

Toxic Substances Hydrology Program

Prepared in cooperation with the

Air Force Center for Engineering and the Environment

Scientific Investigations Report 2013-5061 


\title{
U.S. Department of the Interior SALLY JEWELL, Secretary
}

\section{U.S. Geological Survey Suzette M. Kimball, Acting Director}

\author{
U.S. Geological Survey, Reston, Virginia: 2013
}

For more information on the USGS - the Federal source for science about the Earth, its natural and living resources, natural hazards, and the environment, visit http://www.usgs.gov or call 1-888-ASK-USGS.

For an overview of USGS information products, including maps, imagery, and publications, visit http://www.usgs.gov/pubprod

To order this and other USGS information products, visit http://store.usgs.gov

Any use of trade, product, or firm names is for descriptive purposes only and does not imply endorsement by the U.S. Government.

Although this report is in the public domain, permission must be secured from the individual copyright owners to reproduce any copyrighted materials contained within this report.

Suggested citation:

Barbaro, J.R., Walter, D.A., and LeBlanc, D.R., 2013, Transport of nitrogen in a treated-wastewater plume to coastal discharge areas, Ashumet Valley, Cape Cod, Massachusetts: U.S. Geological Survey Scientific Investigations Report 2013-5061, 37 p., http://pubs.usgs.gov/sir/2013/5061/. 


\section{Contents}

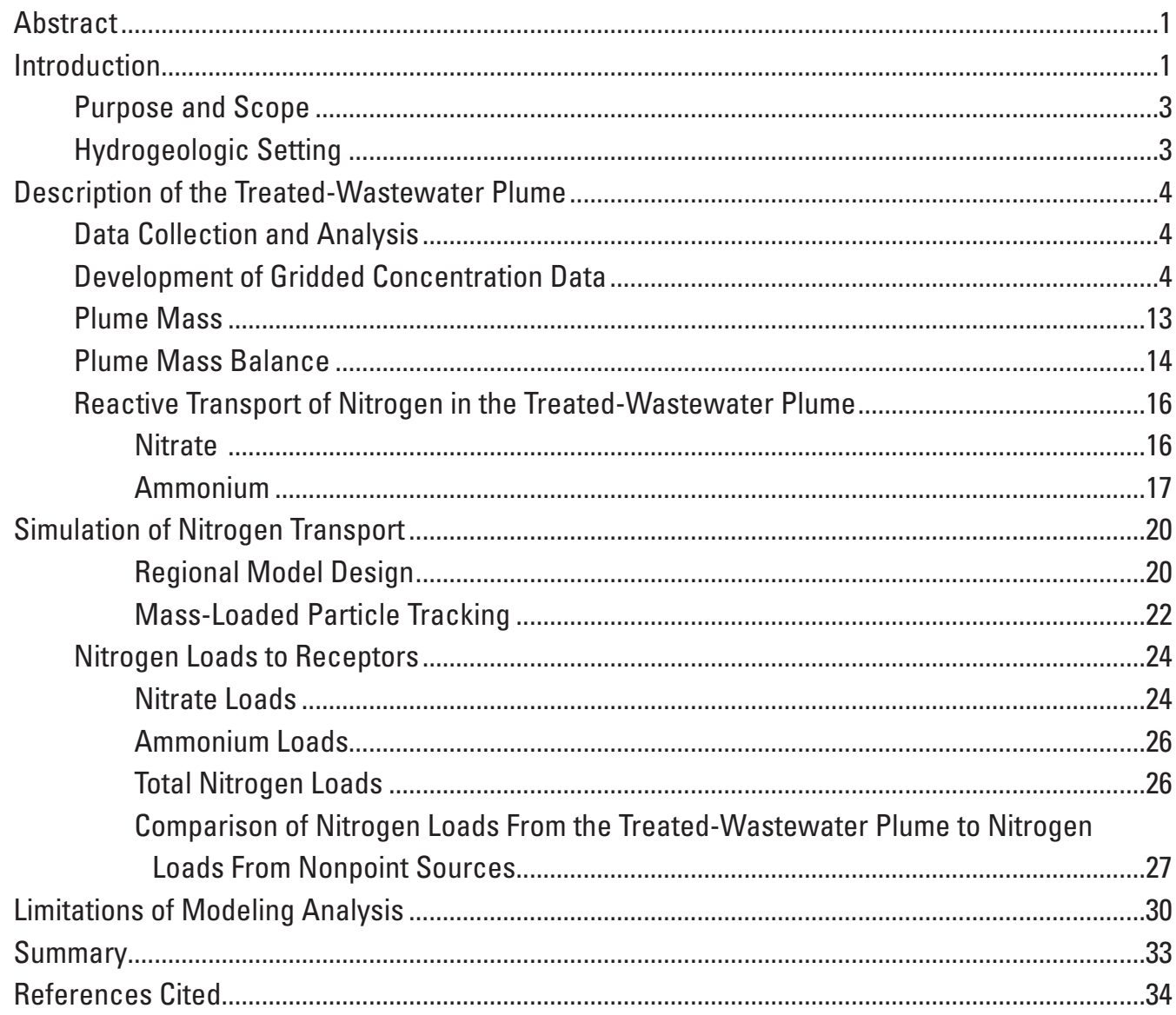

\section{Figures}

1. Map showing the study area, including the locations of the Massachusetts Military Reservation, the treated-wastewater infiltration beds, Ashumet Pond, the Ashumet Valley, and rivers and coastal embayments, western Cape Cod, Massachusetts............2

2. Map showing locations of 2007 sampling sites used in the plume-mapping analysis and sections E-E', F-F', and Z-Z', Ashumet Valley, Cape Cod, Massachusetts ................5

3. Graphs showing vertical nitrate profiles at well cluster F254 for A, sample concentrations and B, interpolated concentrations, Ashumet Valley, Cape Cod, Massachusetts..

4. Graphs showing vertical profiles of dissolved oxygen, nitrate, ammonium, and chloride concentrations in 2007 at sampling sites A, F262, B, F350, C, F271, D, D215, and E, D222, Ashumet Valley, Cape Cod, Massachusetts

5. Map and sections showing distribution of nitrate in 2007. A, Plan view at 16.8 meters below sea level; B, longitudinal section Z-Z'; and C, transverse section E-E', Ashumet Valley, Cape Cod, Massachusetts.

6. Map and sections showing distribution of ammonium in 2007. A, Plan view at 7.6 meters below sea level; B, longitudinal section $Z-Z^{\prime}$; and C, transverse section F-F', Ashumet Valley, Cape Cod, Massachusetts. 
7. Map and sections showing distribution of chloride in 2007. A, Plan view at 16.8 meters below sea level; B, longitudinal section Z-Z'; and C, transverse section $\mathrm{E}-\mathrm{E}^{\prime}$, Ashumet Valley, Cape Cod, Massachusetts.

8. Map and sections showing distribution of boron in 2007. A, Plan view at 16.8 meters below sea level; $B$, longitudinal section $Z-Z^{\prime}$; and $C$, transverse section $E-E^{\prime}$,

Ashumet Valley, Cape Cod, Massachusetts..

9. Graphs showing concentrations of $A$, nitrate compared to specific conductance, and $B$, nitrate and ammonium compared to distance on section $Z-Z^{\prime}$ in 1994 and 2007, Ashumet Valley, Cape Cod, Massachusetts.

10. Graphs showing A, ammonium concentration in 1994 compared to ammonium concentration in 2007 , and $B$, difference in dissolved oxygen concentration between 1994 and 2007 in relation to distance from the infiltration beds for the set of groundwater samples (number of samples $(n)=356$ ) analyzed for ammonium in 1994 and 2007, Ashumet Valley, Cape Cod, Massachusetts.

11. Maps showing distribution of ammonium in A, 1994 and B, 2007 at altitudes of -22.9, $-16.8,-7.6$, and +1.5 meters, Ashumet Valley, Cape Cod, Massachusetts.

12. Map showing rivers and embayments (major receptors) that receive most of the simulated discharge of nitrogen in the treated-wastewater plume, Ashumet Valley, Cape Cod, Massachusetts

13. Map showing three-dimensional steady-state particle tracks originating from the 2007 nitrate plume, Ashumet Valley, Cape Cod, Massachusetts

14. Graphs showing simulated discharge of nitrate in the 2007 treated-wastewater plume to major receptors, Ashumet Valley, Cape Cod, Massachusetts. A, Cumulative nitrate-nitrogen mass, and $B$, nitrate-nitrogen loads...

15. Map showing three-dimensional steady-state particle tracks originating from the 2007 ammonium plume, Ashumet Valley, Cape Cod, Massachusetts.

16. Graphs showing simulated discharge of ammonium in the 2007 treated-wastewater plume to major receptors, Ashumet Valley, Cape Cod, Massachusetts. A, Cumulative ammonium-N mass, and $\mathrm{B}$, ammonium-nitrogen loads

17. Graph showing simulated discharge of total nitrogen in the 2007 treated-wastewater plume to major receptors, Ashumet Valley, Cape Cod, Massachusetts

18. Map showing generalized land use near the treated-wastewater plume, Ashumet Valley, Cape Cod, Massachusetts

\section{Tables}

1. Mass of nitrate, ammonium, chloride, and boron in the treated-wastewater plume in 1994 and 2007, Ashumet Valley, Cape Cod, Massachusetts.

2. Mean concentration and total mass of selected constituents in treated wastewater discharged from1936 to 1995 from the Massachusetts Military Reservation treatment plant, Ashumet Valley, Cape Cod, Massachusetts

3. Median simulated steady-state traveltimes to major receptors for particles originating from the 2007 nitrate and ammonium plumes, Ashumet Valley, Cape Cod, Massachusetts.

4. Steady-state nonpoint-source and peak treated-wastewater plume nitrogen loads to major receptors, Ashumet Valley, Cape Cod, Massachusetts . 


\section{Conversion Factors and Datum}

SI to Inch/Pound

\begin{tabular}{|c|c|c|}
\hline Multiply & By & To obtain \\
\hline \multicolumn{3}{|c|}{ Length } \\
\hline centimeter $(\mathrm{cm})$ & 0.3937 & inch (in.) \\
\hline $\operatorname{meter}(\mathrm{m})$ & 3.281 & foot (ft) \\
\hline kilometer $(\mathrm{km})$ & 0.6214 & mile (mi) \\
\hline \multicolumn{3}{|c|}{ Area } \\
\hline hectare (ha) & 0.4047 & acre \\
\hline square kilometer $\left(\mathrm{km}^{2}\right)$ & 247.1 & acre \\
\hline square meter $\left(\mathrm{m}^{2}\right)$ & 10.76 & square foot $\left(\mathrm{ft}^{2}\right)$ \\
\hline square kilometer $\left(\mathrm{km}^{2}\right)$ & 0.3861 & square mile $\left(\mathrm{mi}^{2}\right)$ \\
\hline \multicolumn{3}{|c|}{ Volume } \\
\hline liter $(\mathrm{L})$ & 0.2642 & gallon (gal) \\
\hline cubic meter $\left(\mathrm{m}^{3}\right)$ & 0.0002642 & million gallons (Mgal) \\
\hline cubic centimeter $\left(\mathrm{cm}^{3}\right)$ & 0.06102 & cubic inch $\left(\mathrm{in}^{3}\right)$ \\
\hline liter $(\mathrm{L})$ & 61.02 & cubic inch $\left(\mathrm{in}^{3}\right)$ \\
\hline cubic meter $\left(\mathrm{m}^{3}\right)$ & 35.31 & cubic foot $\left(\mathrm{ft}^{3}\right)$ \\
\hline \multicolumn{3}{|c|}{ Flow rate } \\
\hline meter per day $(\mathrm{m} / \mathrm{d})$ & 3.281 & foot per day $(\mathrm{ft} / \mathrm{d})$ \\
\hline cubic meter per second $\left(\mathrm{m}^{3} / \mathrm{s}\right)$ & 35.31 & cubic foot per second $\left(\mathrm{ft}^{3} / \mathrm{s}\right)$ \\
\hline liter per second $(\mathrm{L} / \mathrm{s})$ & 15.85 & gallon per minute (gal/min) \\
\hline cubic meter per day $\left(\mathrm{m}^{3} / \mathrm{d}\right)$ & 264.2 & gallon per day (gal/d) \\
\hline \multicolumn{3}{|c|}{ Mass } \\
\hline $\operatorname{gram}(\mathrm{g})$ & 0.03527 & ounce, avoirdupois (oz) \\
\hline kilogram (kg) & 2.205 & pound avoirdupois (lb) \\
\hline \multicolumn{3}{|c|}{ Hydraulic conductivity } \\
\hline meter per day $(\mathrm{m} / \mathrm{d})$ & 3.281 & foot per day (ft/d) \\
\hline
\end{tabular}

Temperature in degrees Celsius $\left({ }^{\circ} \mathrm{C}\right)$ may be converted to degrees Fahrenheit $\left({ }^{\circ} \mathrm{F}\right)$ as follows:

$$
{ }^{\circ} \mathrm{F}=\left(1.8 \times{ }^{\circ} \mathrm{C}\right)+32
$$

Temperature in degrees Fahrenheit $\left({ }^{\circ} \mathrm{F}\right)$ may be converted to degrees Celsius $\left({ }^{\circ} \mathrm{C}\right)$ as follows:

$$
{ }^{\circ} \mathrm{C}=\left({ }^{\circ} \mathrm{F}-32\right) / 1.8
$$

Vertical coordinate information is referenced to the National Vertical Geodetic Datum of 1929 (NVGD 29).

Horizontal coordinate information is referenced to the North American Datum of 1927 (NAD 27).

Altitude, as used in this report, refers to distance above the vertical datum.

Specific conductance is given in microsiemens per centimeter at 25 degrees Celsius $(\mu \mathrm{S} / \mathrm{cm}$ at $\left.25^{\circ} \mathrm{C}\right)$.

Concentrations of chemical constituents in water are given either in milligrams per liter (mg/L) or micrograms per liter $(\mu \mathrm{g} / \mathrm{L})$. 
THIS PAGE INTENTIONALLY LEFT BLANK 


\title{
Transport of Nitrogen in a Treated-Wastewater Plume to Coastal Discharge Areas, Ashumet Valley, Cape Cod, Massachusetts
}

\author{
By Jeffrey R. Barbaro, Donald A. Walter, and Denis R. LeBlanc
}

\section{Abstract}

Land disposal of treated wastewater from a treatment plant on the Massachusetts Military Reservation in operation from 1936 to 1995 has created a plume of contaminated groundwater that is migrating toward coastal discharge areas in the town of Falmouth, Massachusetts. To develop a better understanding of the potential impact of the treated-wastewater plume on coastal discharge areas, the U.S. Geological Survey, in cooperation with the Air Force Center for Engineering and the Environment, evaluated the fate of nitrogen $(\mathrm{N})$ in the plume. Groundwater samples from two large sampling events in 1994 and 2007 were used to map the size and location of the plume, calculate the masses of nitrate- $\mathrm{N}$ and ammonium- $\mathrm{N}$, evaluate changes in mass since cessation of disposal in 1995, and create a gridded dataset suitable for use in nitrogen-transport simulations. In 2007, the treated-wastewater plume was about 1,200 meters (m) wide, $30 \mathrm{~m}$ thick, and 7,700 $\mathrm{m}$ long and contained approximately 87,000 kilograms $(\mathrm{kg})$ nitrate- $\mathrm{N}$ and $31,600 \mathrm{~kg}$ total ammonium-N. An analysis of previous studies and data from the 1994 and 2007 sampling events suggests that most of the biologically reactive nitrogen in the plume in 2007 will be transported to coastal discharge areas as either nitrate or ammonium with relatively little transformation to an environmentally nonreactive end product such as nitrogen gas.

Nitrogen-transport simulations were conducted with a previously calibrated regional three-dimensional MODFLOW groundwater flow model. Mass-loaded particle tracking was used to simulate the advective transport of nitrogen to discharge areas (or receptors) along the coast. In the simulations, nonreactive transport (no mass loss in the aquifer) was assumed, providing an upper-end estimate of nitrogen loads to receptors. Simulations indicate that approximately 95 percent of the nitrate- $\mathrm{N}$ and 99 percent of the ammonium$\mathrm{N}$ in the wastewater plume will eventually discharge to the Coonamessett River, Backus River, Green Pond, and Bournes River. Approximately 76 percent of the total nitrate- $\mathrm{N}$ mass in the plume will discharge to these receptors within 100 years of 2007; 90 and 94 percent will discharge within 200 and 500 years, respectively. Nitrate loads will peak within about 50 years at all of the major receptors. The highest peak loads will occur at the Coonamessett River (450 kg per year $(\mathrm{kg} / \mathrm{yr})$ nitrate-N) and the Backus River (350 kg/yr nitrate-N). Because of adsorption, travel times are longer for ammonium than for nitrate; approximately 5 percent of the total ammonium-N mass in the plume will discharge to receptors within 100 years; 46 and 81 percent will discharge within 200 and 500 years, respectively. The simulations indicate that the Coonamessett River will receive the largest cumulative nitrogen mass and the highest rate of discharge (load). Ongoing discharge to Ashumet Pond is relatively minor because most of the wastewater plume mass has already migrated downgradient from the pond.

To evaluate the contribution of the nitrogen loads from the treated-wastewater plume to total nitrogen loads to the discharge areas, the simulated treated-wastewater plume loads were compared to steady-state nonpoint-source loads calculated by the Massachusetts Estuaries Project for 2005. Simulation results indicate that the total nitrogen loads from the treated-wastewater plume are much lower than corresponding steady-state nonpoint-source loads from the watersheds; peak plume loads are equal to 11 percent or less of the nonpointsource loads.

\section{Introduction}

Land disposal of treated wastewater from a treatment plant on the Massachusetts Military Reservation (MMR) has created a plume of contaminated groundwater in the unconfined aquifer of Cape Cod, Massachusetts. Treated effluent containing phosphorous, nitrogen $(\mathrm{N})$, detergents, metals, and other wastewater-derived constituents was discharged from 1936 to 1995 to rapid-infiltration beds near the southern boundary of the MMR (fig. 1). The disposal created a plume of wastewater-contaminated groundwater that extends south toward Ashumet Pond and the coastal embayments in the town of Falmouth, Massachusetts. In 2007, the treated-wastewater plume was about 1,200 meters (m) wide, $30 \mathrm{~m}$ thick, and $7,700 \mathrm{~m}$ long and was generally aligned with the Ashumet Valley, a local topographic feature that extends from the western 


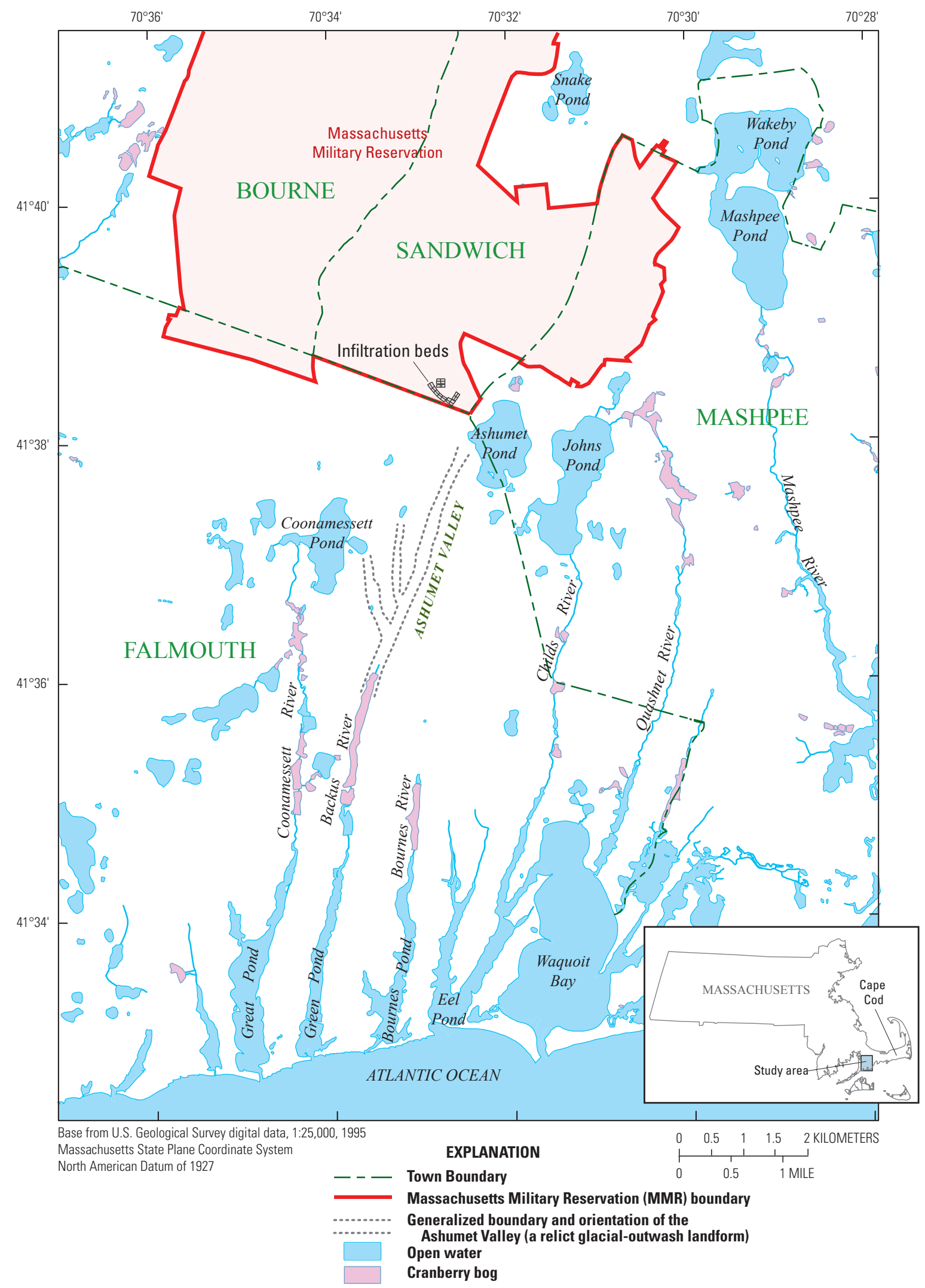

Figure 1. The study area, including the locations of the Massachusetts Military Reservation, the treated-wastewater infiltration beds, Ashumet Pond, the Ashumet Valley, and rivers and coastal embayments, western Cape Cod, Massachusetts. 
side of Ashumet Pond southward to Green Pond. Potential discharge areas for wastewater-contaminated groundwater include the freshwater rivers and ponds and associated saltwater coastal embayments along the coast in Falmouth (fig. 1), collectively referred to as coastal discharge areas. Although parts of the plume have been investigated extensively by the U.S. Geological Survey (USGS) and other researchers since the late 1970s, the three-dimensional (3D) distribution and transport of nitrogen at the plume scale (that is, the entire plume) have received relatively little study.

Nitrate and ammonium are the predominant nitrogen species in the plume, and unlike other nutrients such as phosphorous, they are relatively mobile in groundwater and have the potential to reach coastal discharge areas. Both nitrogen species also are reactive in the plume. Under hypoxic to anoxic conditions and in the presence of a suitable organic substrate, nitrate undergoes denitrification, the microbially mediated reduction of nitrate to nitrogen gas, which is not biologically reactive. Before cessation of wastewater disposal, denitrification was found to be an important process in a reactive zone near the infiltration beds (Smith and Duff, 1988; Smith and others, 1991). In contrast, ammonium undergoes nitrification, the microbially mediated oxidation of ammonium to nitrate that occurs in the presence of dissolved oxygen. Nitrification was found to occur mainly in the mixing zone at the upper boundary of the wastewater plume where both dissolved oxygen and ammonium are present (Böhlke and others, 2006; Smith and others, 2006). If post-cessation biogeochemical conditions are favorable for these reactions at the plume scale, then substantial loss of biologically reactive nitrogen may occur in the aquifer before the plume reaches coastal discharge areas.

The fate of nitrogen in the wastewater plume is of concern because the embayments in Falmouth have received increasing nitrogen loads in response to rapid population growth and development over the past several decades (Bowen and Valiela, 2001; Howes and others, 2005). Excessive nutrient enrichment (eutrophication) adversely affects water quality and aquatic ecosystems (Bowen and others, 2007). Elevated nitrogen concentrations are the result of increased wastewater disposal, atmospheric nitrogen deposition, and fertilizer application, as land use in coastal watersheds changes from forest and open, undeveloped land to residential and commercial development. Discharge from septic systems often is the largest source of nitrogen in these watersheds (Howes and others, 2005; Cole and others, 2006; Kroeger and others, 2006a). The quantity and form of nitrogen reaching individual embayments depends on the density and spatial pattern of residential development in the embayment's watershed (Kroeger and others, 2006a). In coming years, the MMR treated-wastewater plume will contribute to the nitrogen loading to these embayments, but the magnitude, spatial distribution, and timing of its discharge are not well understood.

To develop a better understanding of the the ptotential impact of the treated-wastewater plume on coastal discharge areas, the USGS, in cooperation with the Air Force Center for
Engineering and the Environment, investigated the transport of nitrogen in the plume. The objectives of the study were to calculate the mass of nitrogen in the wastewater plume in 2007, evaluate the occurrence and extent of reactions that could reduce the mass of nitrogen in the aquifer before discharge, simulate the spatial and temporal discharge of nitrogen to the rivers and coastal embayments in Falmouth, and compare treated-wastewater plume loads to steady-state nonpointsource loads. The first two objectives were met by analyzing large groundwater datasets collected in 1994 and 2007 and reviewing results from previous studies on the reactivity of nitrogen in the plume. Nitrogen discharge was evaluated by simulating the movement of the plume with an existing groundwater flow model.

\section{Purpose and Scope}

The purpose of this report is to describe an investigation of the fate of nitrogen in the MMR treated-wastewater plume on Cape Cod, Massachusetts. Groundwater samples from two sample-collection events, referred to as the 1994 and 2007 snapshots, were used to determine the size and location of the wastewater plume, calculate the masses of reactive nitrogen species and conservative constituents (chloride and boron) in the plume, and evaluate the reactivity of nitrogen species at the plume scale.

This report also describes nitrogen-transport simulations conducted with a previously calibrated 3D MODFLOW groundwater flow model and advective particle tracking. The report briefly describes the development of the groundwater flow model and details the results of nonreactive transport simulations conducted to estimate wastewater-plume nitrogen loads to coastal discharge areas. The report also compares the simulated wastewater-plume loads to published nonpointsource loads to these coastal discharge areas.

\section{Hydrogeologic Setting}

The unconfined aquifer of western Cape Cod consists of glacial drift deposited during the late Wisconsinan stage of the Pleistocene Epoch (Masterson and others, 1997). The study area is on an outwash plain deposited as a progradational deltaic sequence. Outwash-plain sediments fine downward and consist of stratified medium-to-coarse-grained glaciofluvial sand and gravel underlain by fine-to-medium-grained glaciolacustrine sand and silt. Ice-block collapse sedimentary structures and kettle ponds are common features in the outwash plain. The stratified drift is underlain in most places by a thin layer of basal till. The glacial deposits are underlain by crystalline bedrock, which is impermeable relative to the drift and forms the base of the unconfined aquifer. Regional groundwater flow on western Cape Cod has a radial pattern that extends outward from a circular groundwater mound near Snake Pond toward the surrounding coastlines (Walter and Masterson, 2003). Areal recharge from precipitation is the major external 
source of water to the aquifer; the recharge rate on Cape Cod and southeastern Massachusetts is approximately 0.68 meters per year (m/yr; Masterson and others, 1998; Walter and

Masterson, 2003; Masterson and others, 2009).

The aquifer is approximately $80 \mathrm{~m}$ thick in the study area. The altitude of the water table decreases from about $15 \mathrm{~m}$ above sea level at the infiltration beds to sea level at the coast, a distance of about 10 kilometers $(\mathrm{km})$. The unsaturated zone is about $6 \mathrm{~m}$ thick beneath the infiltration beds. Groundwater flow is predominantly horizontal except near discharge boundaries such as Ashumet Pond and the coast where vertical flow is evident (McCobb and others, 2003). Horizontal groundwater flow velocities are in the range of 0.2 to 0.7 meters per day (m/d) (LeBlanc, 1984a).

Ashumet Pond, an 88-hectare, flow-through kettle pond, substantially affects the local groundwater-flow field and the wastewater plume originating from the infiltration beds, which are about $1 \mathrm{~km}$ to the northwest of the pond (fig. 1). Kettle ponds receive water by groundwater inflow and direct precipitation, and lose water by pond water outflow and evaporation. Because precipitation exceeds evaporation on Cape Cod, kettle ponds in this region are areas of net recharge (Walter and others, 2002). The flow-through nature of kettle ponds creates a spatial pattern in which groundwater flow converges toward ponds in upgradient areas and diverges away from them in downgradient areas. The extent of the influence on the groundwater-flow field is determined by the size and bathymetry of the pond, thickness of the aquifer, hydraulic conductivity of pond-bottom sediments, and temporal variability in precipitation and aquifer recharge (Walter and others, 2002). Under variable recharge conditions, simulated and measured horizontal groundwater-flow directions were found to vary by 20 to 45 percent near Ashumet Pond (Walter and Masterson, 2003; McCobb and others, 1999) as groundwater-flow patterns and the position of the hinge line (the line that separates the area of the pond receiving water from the area losing water) shift with fluctuating groundwater levels. Away from the pond, transient changes in the magnitudes of gradients and directions of groundwater flow are small (Walter and Masterson, 2003).

Both the spatial and temporal variability of the flow field near Ashumet Pond have implications for the fate of the wastewater plume. Reactive wastewater constituents such as nitrate and ammonium that discharge into the pond are likely attenuated by trophic processes in the pond. In contrast, conservative plume constituents such as chloride and boron are diluted and then discharged back into the aquifer in the pond water outflow. The discharged pond water, which may extend nearly to the bedrock, lies to the east of the treated-wastewater plume. In this study, the discharged pond water is not considered to be part of the wastewater plume. The temporal variability of the flow field near the pond (and the infiltration beds) may also affect the wastewater plume; flow simulations indicate that transient fluctuations in advective flow directions near the infiltration beds produce a wider wastewater plume than otherwise would develop in a steady-state flow field (Walter and Masterson, 2003).

\section{Description of the Treated-Wastewater Plume}

The size and location of the plume has been determined periodically by snapshot sampling, which is defined as a comprehensive sampling of the monitoring network over a short time interval of several months. As the most current snapshot for the plume, the 2007 snapshot was used to determine the size and location of the treated-wastewater plume and the total mass of nitrogen in the plume. The 1994 snapshot also was evaluated to compare changes in the plume between 1994 (before cessation of wastewater disposal in 1995) and 2007. Nitrogen species (nitrate and ammonium), dissolved oxygen, conservative constituents (chloride and boron), and specific conductance were evaluated in detail for this study.

\section{Data Collection and Analysis}

Groundwater samples were collected by the USGS from observation-well clusters, multilevel samplers (MLSs), and direct-push borings. At nearly all sites, vertical concentration profiles were obtained, ranging from 2 samples in some well clusters to about 40 samples in the MLSs. The datasets from 1994 and 2007 differ in the number and locations of sampled sites, but both are adequate for mapping the wastewater plume in three dimensions and estimating contaminant mass. For the 1994 snapshot, approximately 760 samples were collected from 107 well-cluster and MLS sites (Savoie and LeBlanc, 1998). For the 2007 snapshot, approximately 1,160 samples were collected from 154 well-cluster, MLS, and direct-push sites (Savoie and others, 2012). Descriptions of well installation, sampling techniques, analytical methods, quality-control procedures, and the tabulated data are provided in Savoie and LeBlanc (1998) and Savoie and others (2012).

\section{Development of Gridded Concentration Data}

Concentration data were interpolated onto a $3 \mathrm{D}$ grid to calculate contaminant mass in the plume in 1994 and 2007 and create gridded concentration datasets suitable for use in nitrogen-transport simulations. Gridded datasets were created for nitrate-N, ammonium-N, chloride, boron, and specific conductance. To develop the gridded concentration data, the 1994 and 2007 datasets were screened to remove samples from wells or MLSs in densely sampled parts of the plume that were deemed to be redundant, long-screened wells that were not part of a vertical cluster, and locations that were outside (generally above) the interpreted plume boundaries. The screened 1994 dataset consists of 534 samples from 70 sampling sites, and the screened 2007 dataset consists of 1,005 samples from 122 sampling sites (fig. 2). In 1994, samples from the MLSs were not analyzed for chloride, so the screened dataset for chloride consists of 236 samples from 62 sampling sites. Despite the size of the datasets, well locations were not 


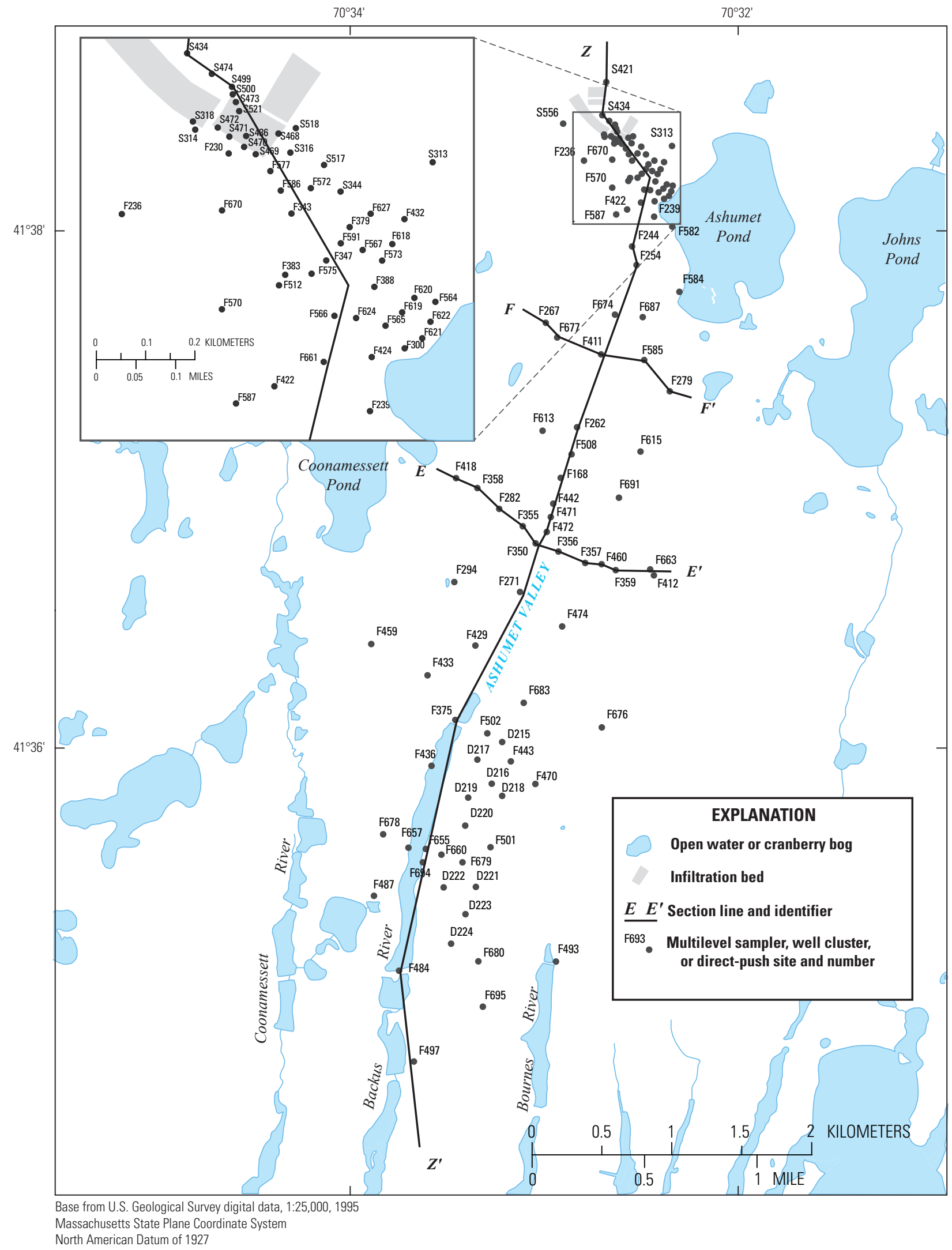

Figure 2. Locations of 2007 sampling sites used in the plume-mapping analysis and sections $E-E^{\prime}, F-F^{\prime}$, and $Z-Z^{\prime}$, Ashumet Valley, Cape Cod, Massachusetts. 
sufficiently spread out to completely define the size and shape of the wastewater plume. Consequently, control points and hydrologic judgment were used to fill in data gaps so that the locations of the upper, lower, and lateral boundaries of the wastewater plume could be delineated, as described below.

To develop the gridded datasets, each vertical concentration profile was first filled out by linearly interpolating concentrations between each sample pair in the profile. Interpolated profiles contained values at 0.30 -m vertical intervals (fig. 3 ). To develop complete profiles, it was necessary to determine the locations of the upper and lower plume boundaries. The upper plume boundary typically was identified by the sharp dissolved oxygen, chloride, boron, specific conductance, and ammonium concentration gradients between the plume and the lens of uncontaminated groundwater above the plume that is produced by areal recharge. For example, detailed vertical concentration profiles obtained in 2007 indicate that the position of the upper boundary declines from an altitude of about $-5 \mathrm{~m}$ at F262 (2,350 $\mathrm{m}$ from the infiltration beds) to about $-14 \mathrm{~m}$ at D222 (5,800 $\mathrm{m}$ from the infiltration beds) as the recharge lens pushed the plume deeper into the aquifer with increasing distance from the source area (fig. 4). The high chloride concentrations above the top of the plume likely are the result of road salting along Mass. Route 151 (LeBlanc, 1984a). The high nitrate concentrations in the recharge lens apparently are from nonpoint sources such as septic-system discharge and inorganic fertilizer application.

Because of a paucity of concentration data, the position of the lower boundary was more difficult to discern than the upper plume boundary; available data from deeper samples indicated that the plume was about $33 \mathrm{~m}$ thick. Consequently, it was assumed that the lower plume boundary was approximately $33 \mathrm{~m}$ below the upper plume boundary at all sampling sites. LeBlanc (1984a) shows the bottom of the plume coinciding with a lithologic boundary between permeable sand and gravel and less permeable fine-grained sediments. The altitude of the boundary rises from about -33 to $-23 \mathrm{~m}$ below sea level over a distance extending 4,500 $\mathrm{m}$ downgradient from the infiltration beds (fig. 17; LeBlanc, 1984a). Beyond 4,500 m, lithologic data are not available to determine the altitude, thickness, and areal extent of the fine-grained layer. Because constituent concentrations appeared to be elevated below the altitude of the lithologic boundary in the 0 - to 4,500 - $\mathrm{m}$ interval (fig. 4) and the occurrence and location of the boundary farther downgradient is uncertain, the top of the fine-grained sediments generally does not coincide with the base of the plume in the current study. However, if these sediments are areally extensive in the Ashumet Valley, then they likely affect groundwater-flow paths and the vertical location of the plume downgradient from the infiltration beds.

Between the 1994 and 2007 snapshots, two substantial changes to the groundwater-flow system occurred that potentially affected the plume boundaries. Wastewater disposal ceased in 1995 and a remedial system designed to control chlorinated-solvent migration was installed in 1999 (Air Force Center for Engineering and the Environment, 2010). The

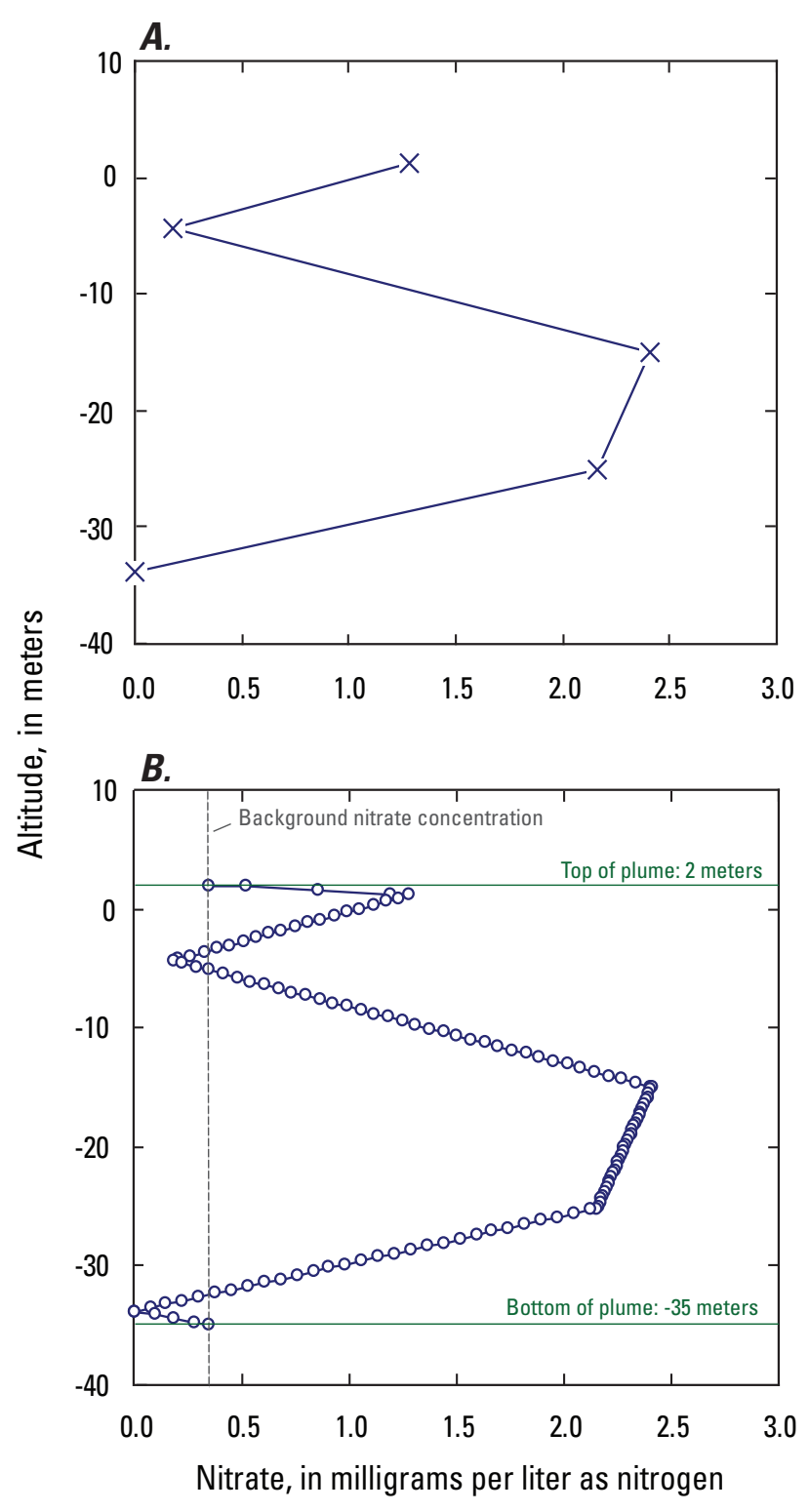

Figure 3. Vertical nitrate profiles at well cluster F254 for $A$, sample concentrations and $B$, interpolated concentrations, Ashumet Valley, Cape Cod, Massachusetts. Location of well cluster shown on figure 2. 

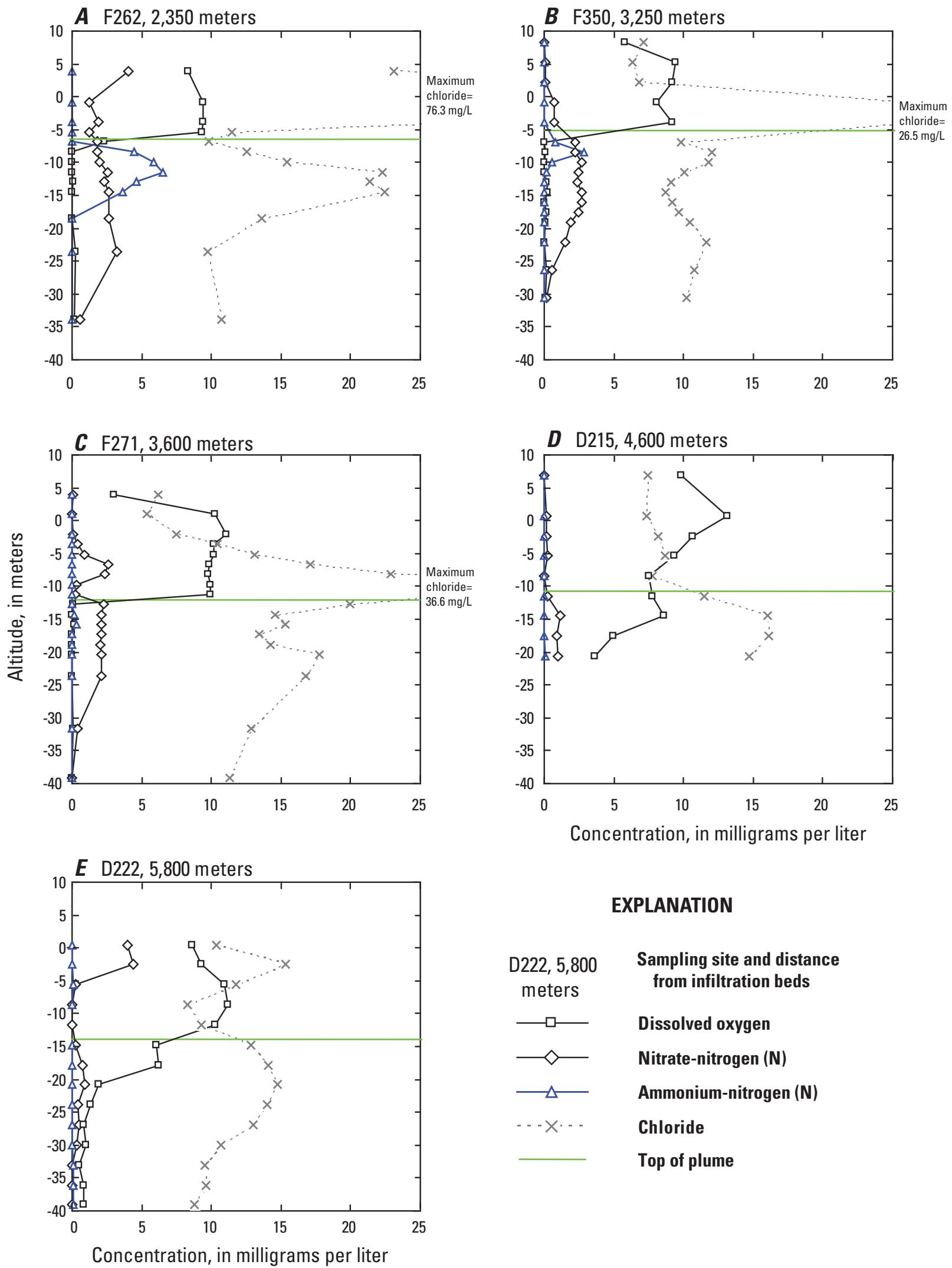

\section{EXPLANATION}

\begin{tabular}{|c|c|}
\hline $\begin{array}{l}\mathrm{D} 222,5,800 \\
\text { meters }\end{array}$ & $\begin{array}{l}\text { Sampling site and distance } \\
\text { from infiltration beds }\end{array}$ \\
\hline$\square-$ & Dissolved oxygen \\
\hline$\diamond$ & Nitrate-nitrogen (N) \\
\hline$\Delta \longleftarrow$ & Ammonium-nitrogen (N) \\
\hline$\cdots \times \cdots$ & Chloride \\
\hline & Top of plume \\
\hline
\end{tabular}

Figure 4. Vertical profiles of dissolved oxygen, nitrate, ammonium, and chloride concentrations in 2007 at sampling sites $A$, F262, $B$, F350, C, F271, D, D215, and E, D222, Ashumet Valley, Cape Cod, Massachusetts. Locations of sampling sites shown on figure 2. 
remedial system consisted of three extraction wells and two shallow infiltration trenches for treated water and was located near section $E-E^{\prime}$ (fig. 2). Concentration data indicated that the position of the upper plume boundary was not appreciably affected by these changes to the flow system. Consequently, the same upper and lower boundary altitudes were used to delineate the treated-wastewater plume in 1994 and 2007.

At most sites, vertical concentration profiles included samples from the recharge lens above the plume; these samples were not used in the analysis. At other sites, concentration data and altitudes of the sampling points indicated that the uppermost sample in the profile was below the upper plume boundary. At nearly all sites, concentration data and altitudes indicated that the lowermost sample in the profile was above the lower plume boundary. Therefore, to calculate complete interpolated vertical concentration profiles, it was necessary to insert control points at the upper and lower plume boundaries at nearly all sampling sites in the 1994 and 2007 datasets. Control points were assigned concentrations representing background groundwater quality $(0.35$ milligrams per liter (mg/L) nitrate-N; $0 \mathrm{mg} / \mathrm{L}$ ammonium-N; $10 \mathrm{mg} / \mathrm{L}$ chloride; 6 micrograms per liter $(\mu \mathrm{g} / \mathrm{L})$ boron; and 50 microsiemens per centimeter at 25 degrees Celsius $(\mu \mathrm{S} / \mathrm{cm})$ specific conductance. Background concentrations were consistent with values used in other studies of the wastewater plume and Cape Cod groundwater (Persky, 1986; Ceazan and others, 1989; Frimpter, 1990; Parkhurst and others, 2003; Kroeger and others, 2006b; Repert and others, 2006). At a few sites, control points also were added within the plume to fill in large vertical gaps between sampling sites and the interpreted plume boundaries. For samples with concentrations reported as less than the detection limit, the value of the detection limit was used for boron and chloride, whereas zero was used for nitrate and ammonium because these constituents may be fully consumed by reactions within the plume. Because there were relatively few of these samples and detection limits are low relative to concentrations in the plume (Savoie and LeBlanc, 1998; Savoie and others, 2012), the choice of zero or the detection limit had a small effect on nitrogen mass and distribution.

Nineteen horizontal layers from altitudes of $-41.1 \mathrm{~m}$ $(-135 \mathrm{ft})$ to $+13.7 \mathrm{~m}(+45 \mathrm{ft})$ at $3-\mathrm{m}(10-\mathrm{ft})$ vertical intervals were created from the interpolated vertical concentration profiles. Each layer contained a concentration value for each sampling site. For example, for the 2007 dataset, each layer contained 122 concentration values, although for layers near the top and bottom of the plume, many of the values were at background concentrations, indicating that the plume was not present at that location. Most of the data in a layer are interpolated values rather than actual sample concentrations because few well-screen or sampling-port altitudes coincide with layer altitudes. For each layer, the ArcGIS TOPOGRID procedure was used to interpolate the concentration data to an orthogonal grid. The interpolation procedure requires a bounding polygon to enclose the concentration data, which served as the lateral plume boundary. The bounding polygon size and shape for each layer was based on the concentration data at that altitude, and, to a lesser extent, on the simulated steady-state hydraulichead distribution. Because the spatial extents of the mobile constituents were similar, a single set of 19 bounding polygons was used for the nitrate, chloride, and boron plumes, whereas a second set was used for the smaller ammonium plume. Bounding polygons were assigned concentrations representing background groundwater quality. Thus, the plumes of the various constituents were defined as the volumes of the aquifer with concentrations generally above the constituents' respective background levels. It should be noted that in the lowconcentration parts of the plume, concentrations may be lower than background concentrations.

The horizontally interpolated layers were stacked on top of each other to form the 3D depiction of the wastewater plume. Groundwater Modeling System (GMS) version 7.0 (Aquaveo, 2012) software was used visualize the 3D contours of the plume and create vertical and horizontal cross-sections at selected locations (figs. 5-8). On the basis of the interpolated data, the wastewater plume, as defined by nitrate, chloride, and boron concentrations, was approximately $1,200 \mathrm{~m}$ wide, $30 \mathrm{~m}$ thick, and 7,700 $\mathrm{m}$ long in 2007 (1994 plume not shown). Consistent with a relatively slow migration rate, the ammonium plume was substantially smaller than the nitrate plume, extending roughly 3,300 $\mathrm{m}$ downgradient from the infiltration beds in 2007 (fig. 6). The spatial heterogeneity of the solutes is best represented near the infiltration beds and Ashumet Pond because the sample density is greatest in that part of the plume. The wastewater plume is substantially wider than the infiltration beds mainly because the steady-state flow field diverges downgradient from Ashumet Pond. Transient flow near Ashumet Pond may also cause lateral spreading closer to the beds.

The position of the upper boundary of the plume is relatively well defined, followed by the position of the lateral boundaries. The positions of the lower boundary and downgradient edge of the plume are less well defined. The downgradient extent of the plume, in particular, is poorly defined, and longitudinal dispersion creates a large mixing zone so that the mapped plume length will be dependent on the concentration used to differentiate contaminated from uncontaminated water. The farthest downgradient well cluster, F497, is about $7 \mathrm{~km}$ from the infiltration beds and appears to be within the plume. The maximum downgradient extent of the wastewater plume in 2007 was assumed to be approximately $0.7 \mathrm{~km}$ beyond this well cluster (figs. 7 and 8 ). This plume length (7.7 $\mathrm{km}$ ) is roughly consistent with the results of a Darcy's Law calculation: the 71-year (1936-2007) travel distance for the mean position of a contaminant front migrating at an average linear groundwater velocity of $0.3 \mathrm{~m} / \mathrm{d}$ is $7.8 \mathrm{~km}$. It should be noted, however, that if the average linear groundwater velocity was $0.4 \mathrm{~m} / \mathrm{d}$, a reasonable rate for the conductive upper part of the aquifer (LeBlanc, 1984a), then the mean position of the contaminant front would be more than $10 \mathrm{~km}$ from the source area. 
A.

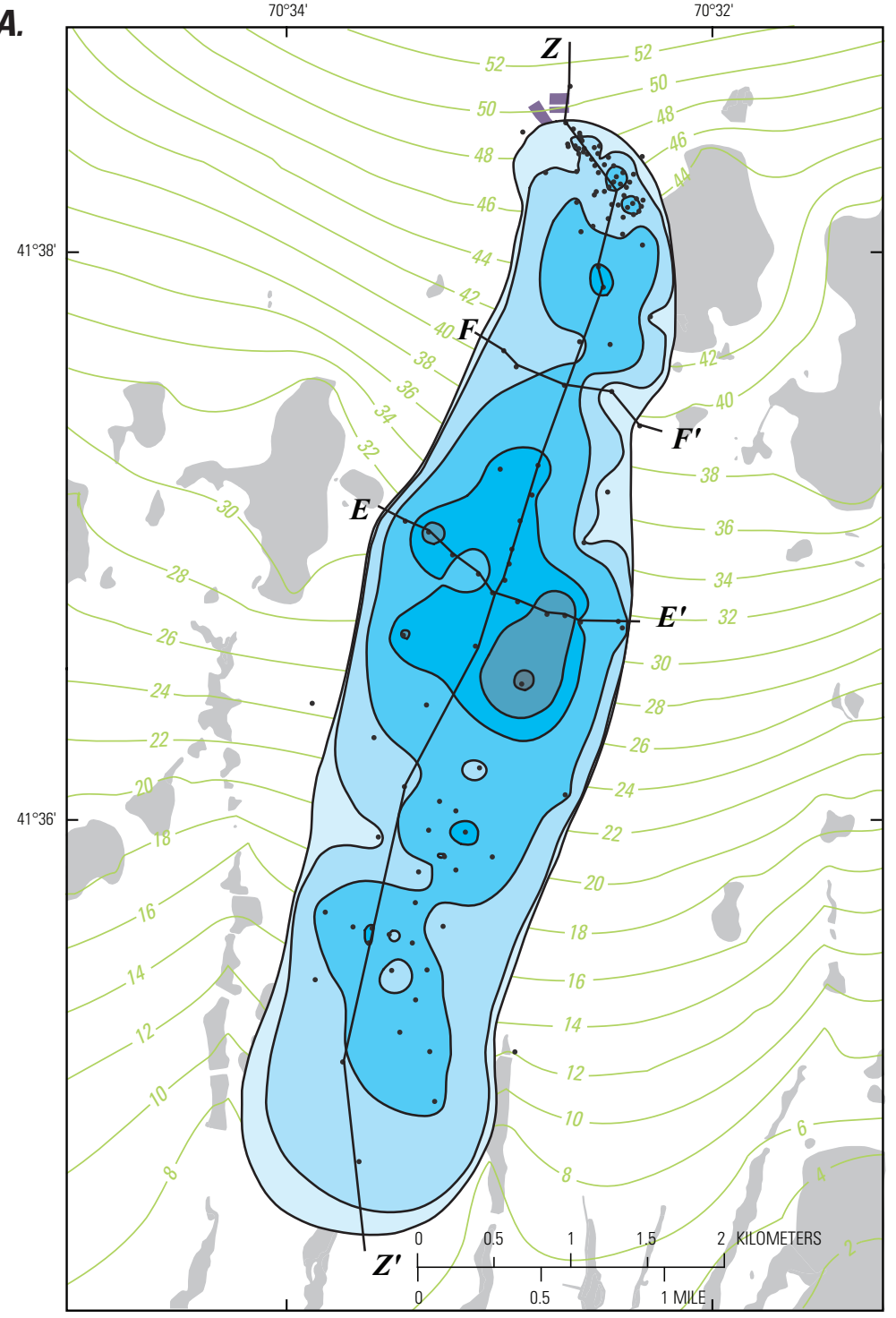

Base from U.S. Geological Survey digital data,

Massachusetts State Plane Coordinate System,

North American Datum of 1927

B. $Z$

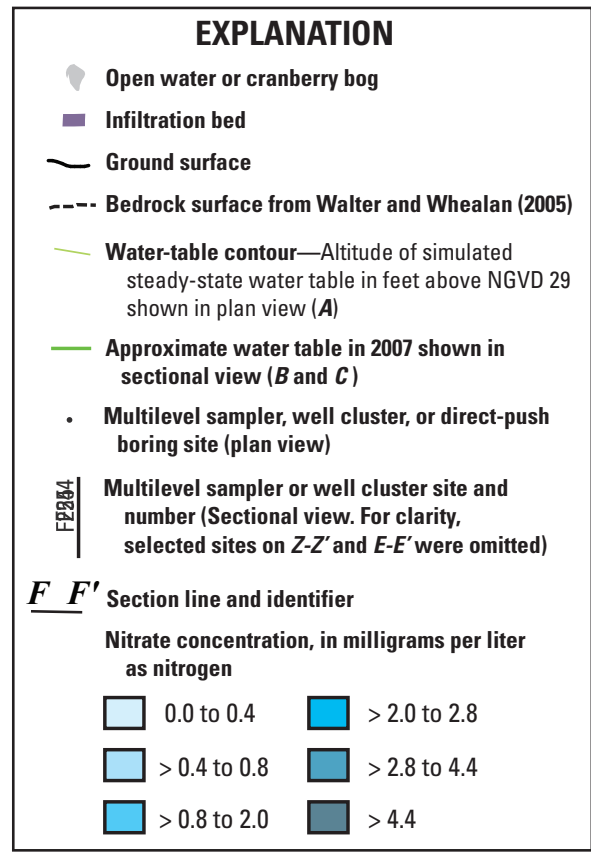

C

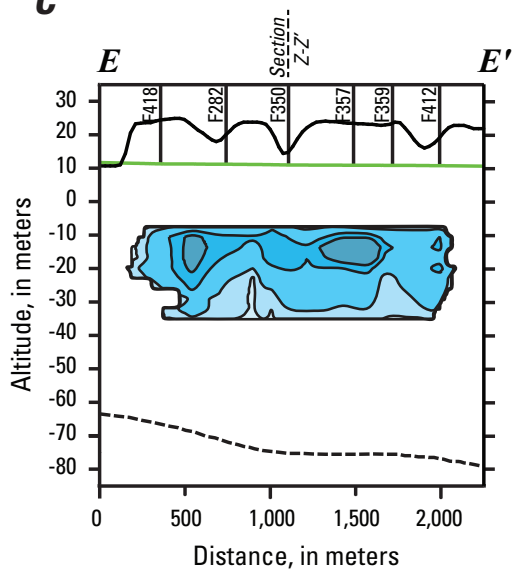

$20 x$ vertical exaggeration

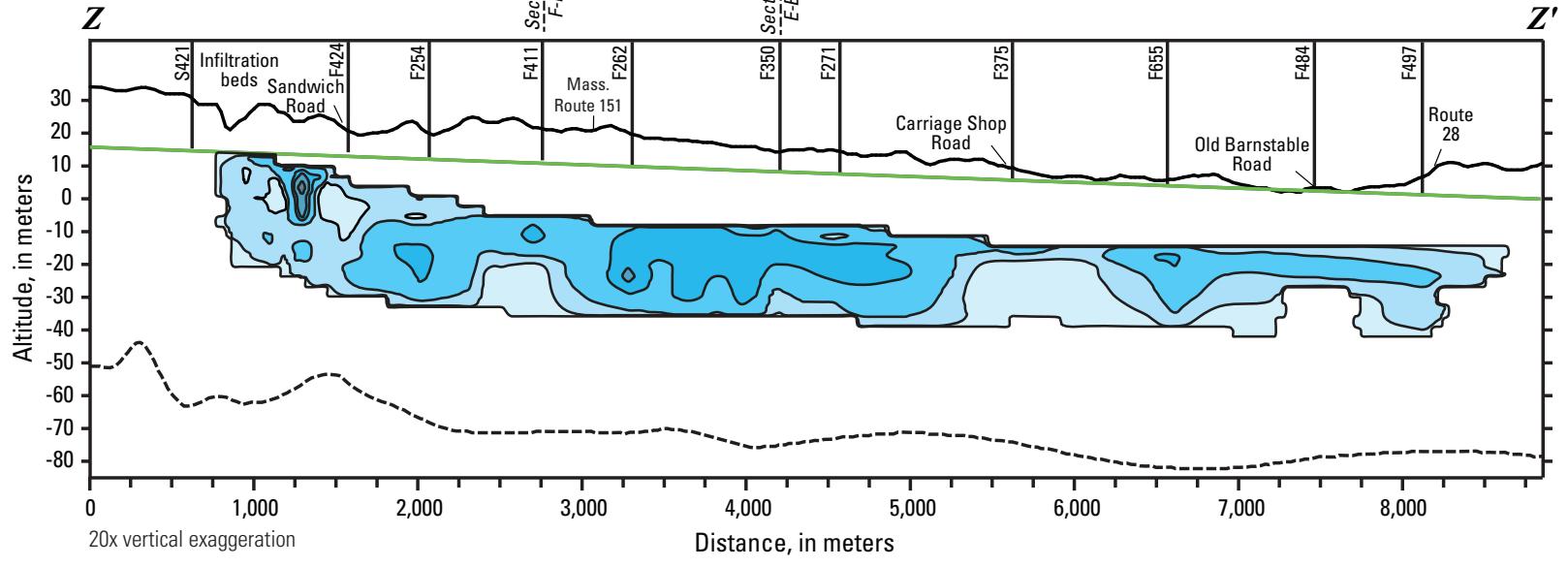

Figure 5. Distribution of nitrate in 2007. $A$, Plan view at 16.8 meters below sea level; $B$, longitudinal section $Z-Z^{\prime}$; and $C$, transverse section $E-E^{\prime}$, Ashumet Valley, Cape Cod, Massachusetts. Section locations shown in figure 2. 


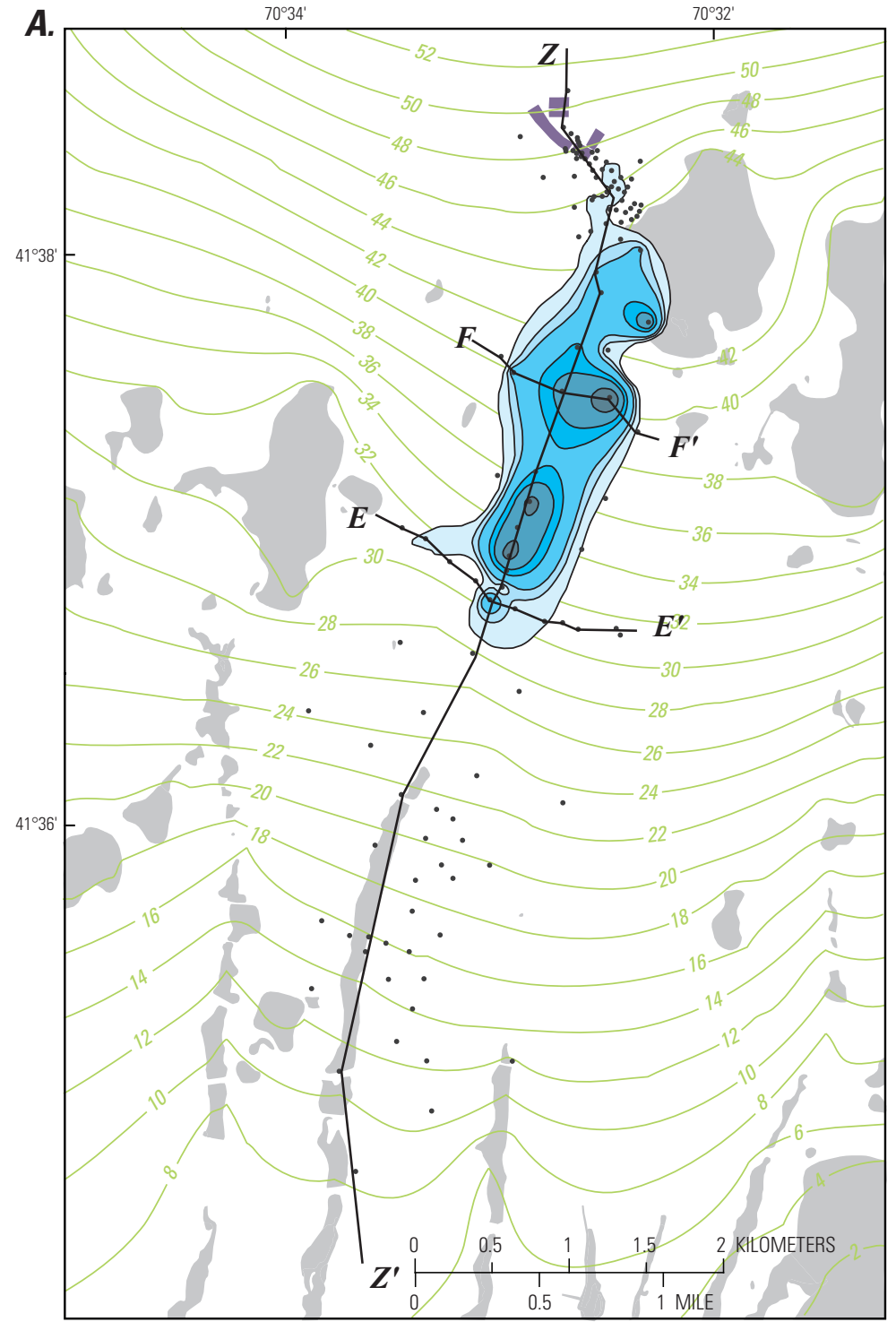

Base from U.S. Geological Survey digital data,

Massachusetts State Plane Coordinate System,

North American Datum of 1927

National Geodetic Vertical Datum of 1929

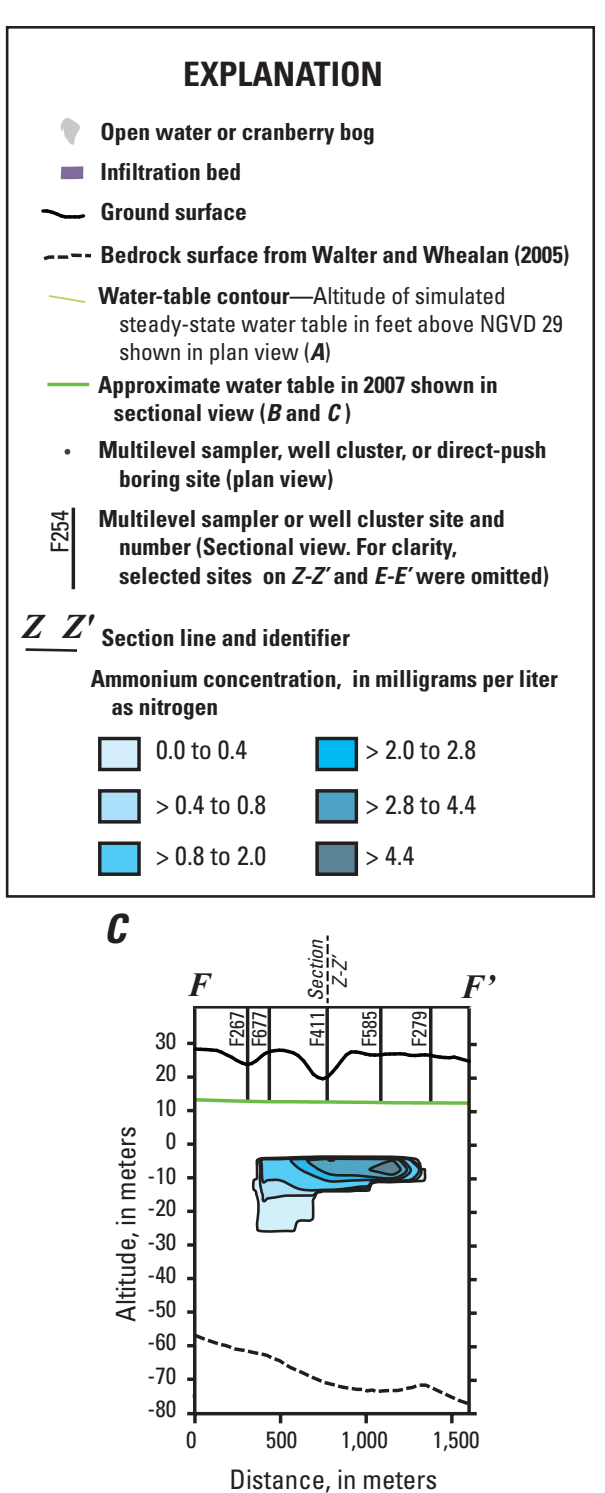

20x vertical exaggeration

B.

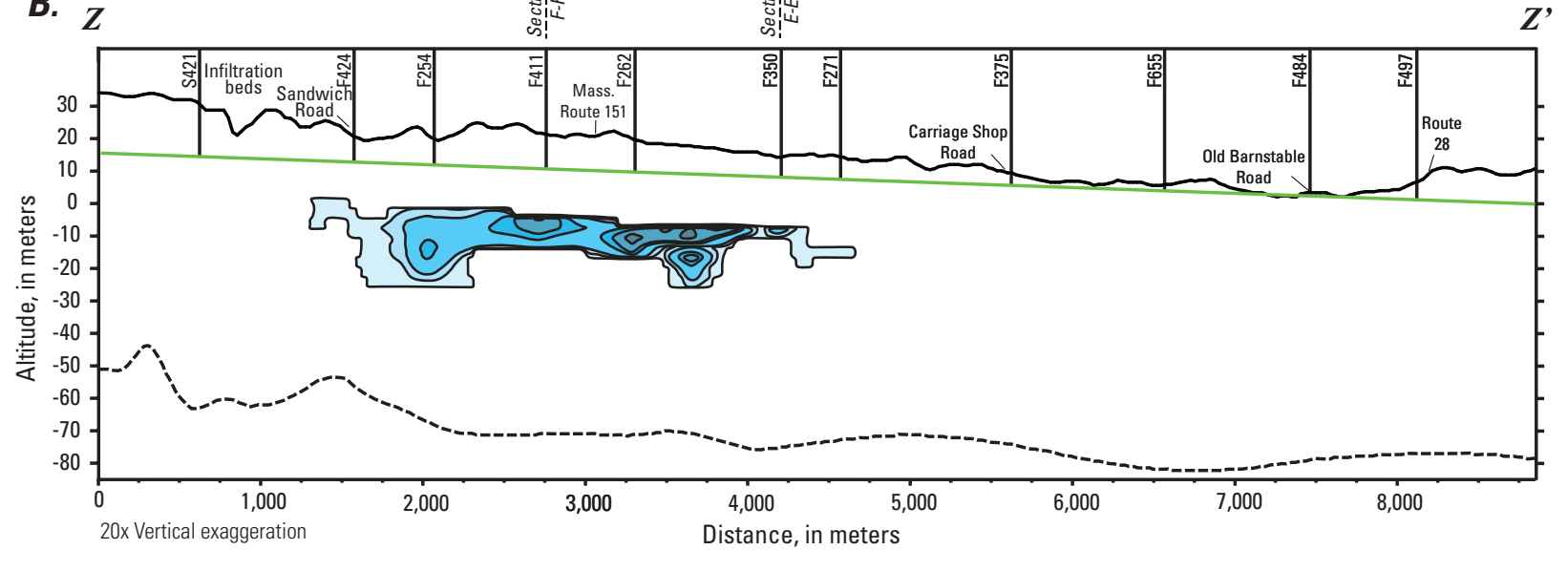

Figure 6. Distribution of ammonium in 2007. $A$, Plan view at 7.6 meters below sea level; $B$, longitudinal section $Z-Z$;' and $C$, transverse section $F-F^{\prime}$, Ashumet Valley, Cape Cod, Massachusetts. Section locations shown in figure 2. 


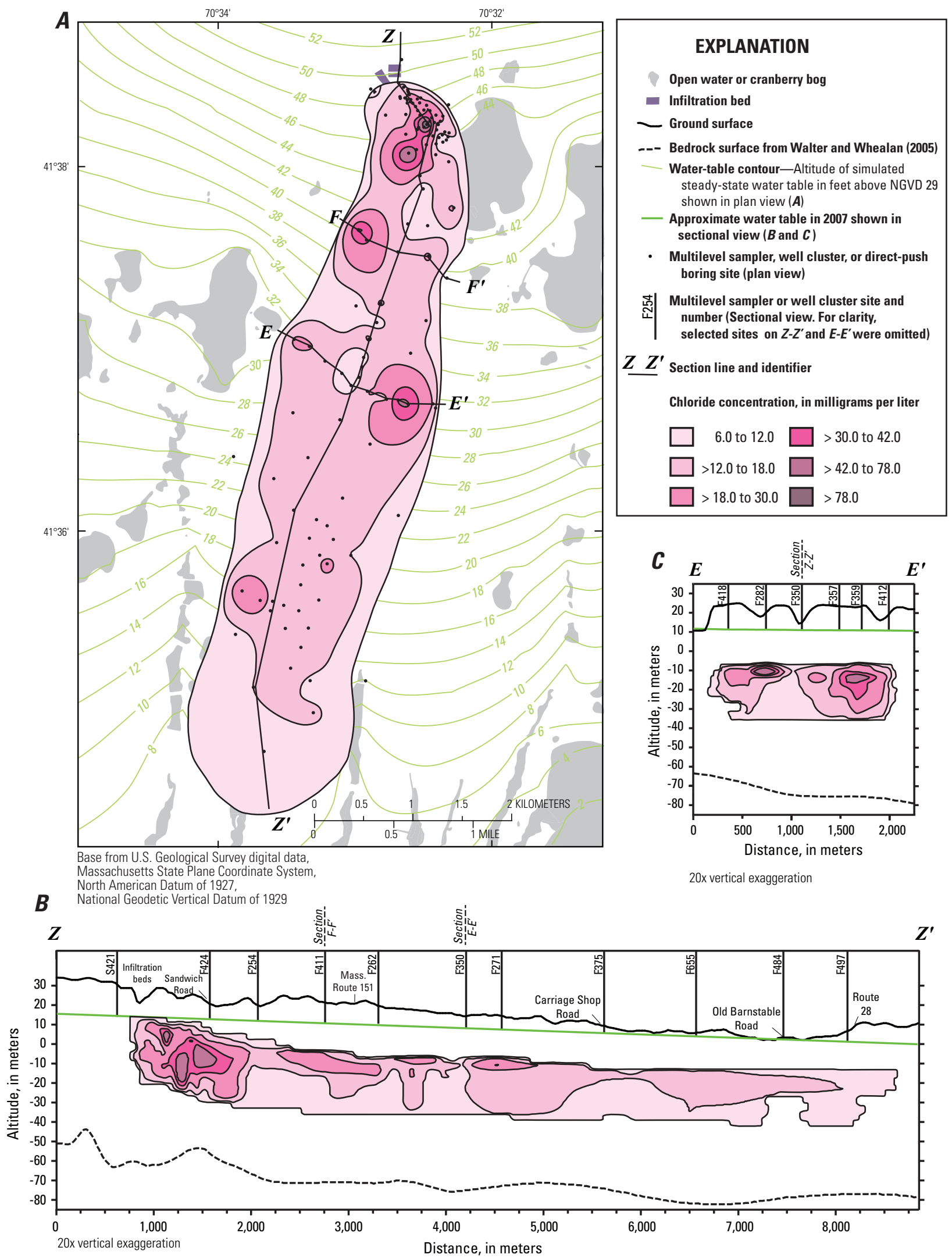

Figure 7. Distribution of chloride in 2007. $A$, Plan view at 16.8 meters below sea level; $B$, longitudinal section $Z-Z^{\prime}$; and $C$, transverse section $E-E^{\prime}$, Ashumet Valley, Cape Cod, Massachusetts. Section locations shown in figure 2. 


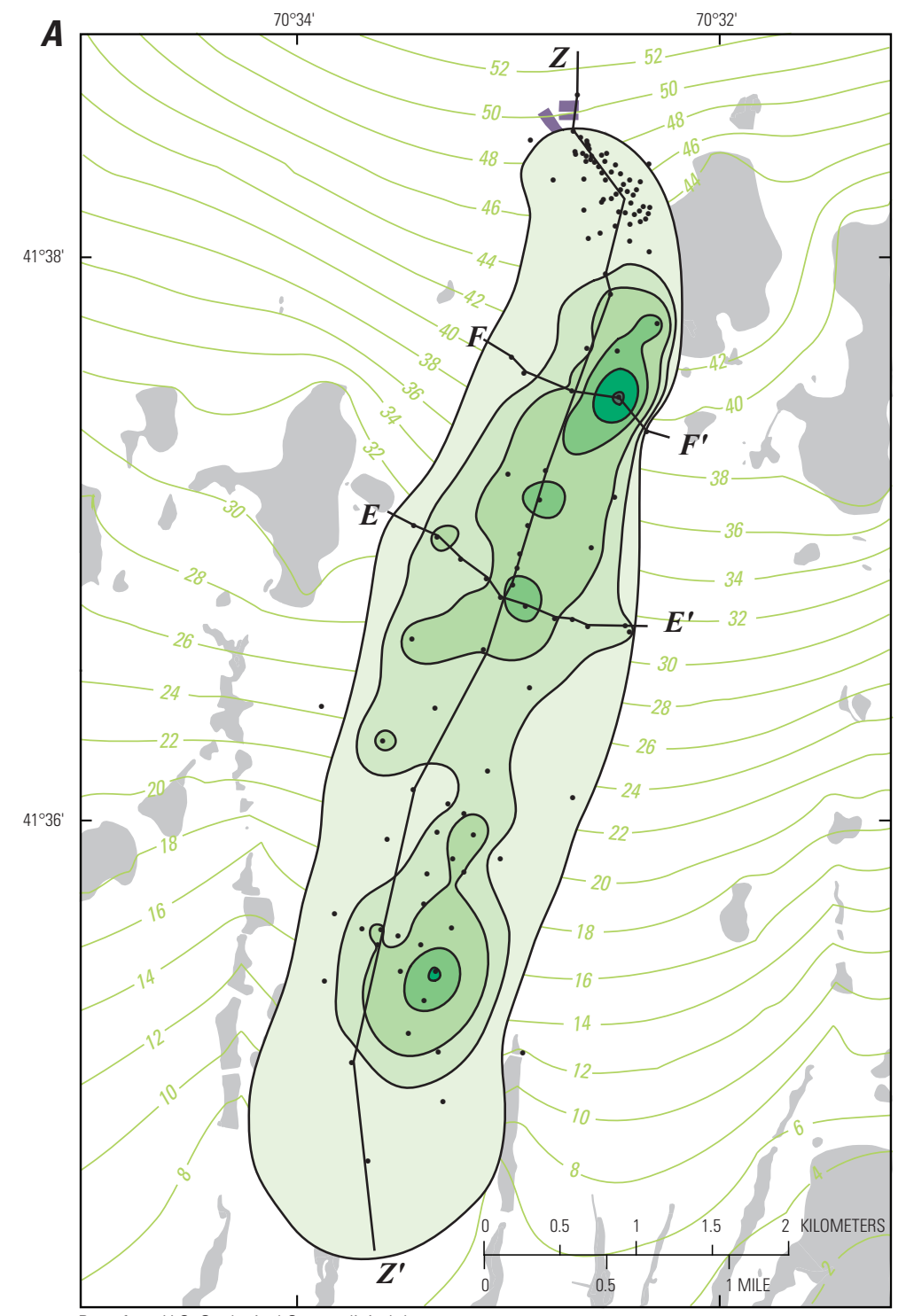

Base from U.S. Geological Survey digital data, Massachusetts State Plane Coordinate System, North American Datum of 1927 ,

National Geodetic Vertical Datum of 1929
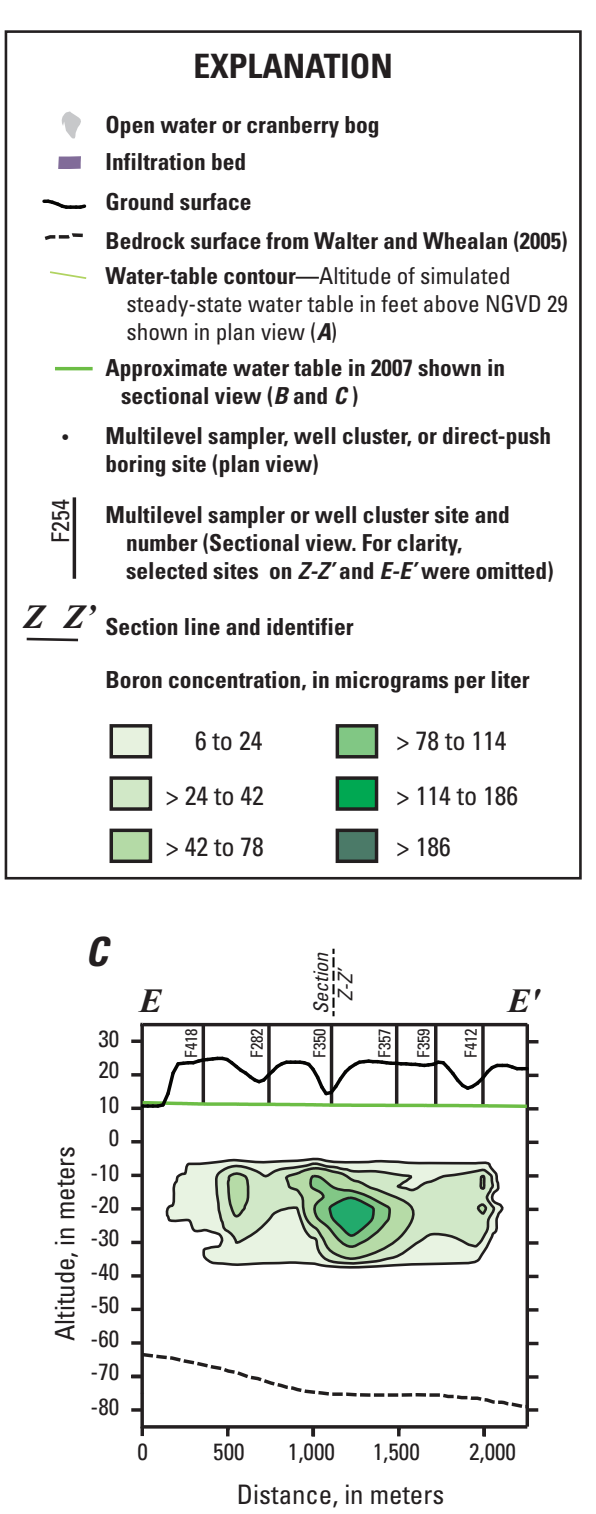

20x vertical exaggeration

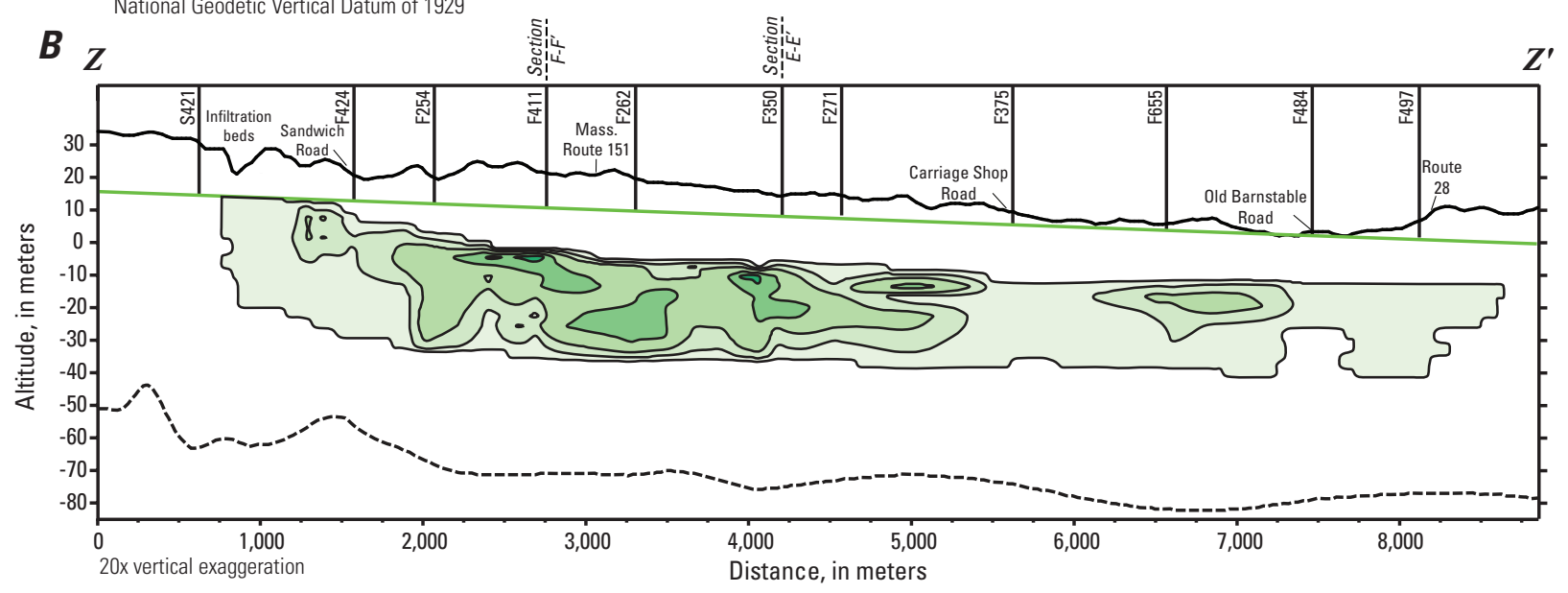

Figure 8. Distribution of boron in 2007. A, Plan view at 16.8 meters below sea level; $B$, longitudinal section $Z-Z$;' and $C$, transverse section $E-E^{\prime}$, Ashumet Valley, Cape Cod, Massachusetts. Section locations shown in figure 2. 


\section{Plume Mass}

Gridded concentration data were used to calculate the total mass of nitrate- $\mathrm{N}$, ammonium-N, boron and chloride in the treated-wastewater plume in 1994 and 2007. Masses of other nitrogen species, such as nitrite and organic $\mathrm{N}$, were not calculated. In 2007, the numbers of samples for nitrite and organic $\mathrm{N}$ were insufficient to calculate the total mass in the plume. In 1994, the numbers of samples were sufficient, but concentrations of both constituents in the plume were relatively low. Nitrite-N concentrations were below the detection limit in most samples, with a maximum value of $0.87 \mathrm{mg} / \mathrm{L}$ at F566 (Savoie and LeBlanc, 1998). Organic-N was detected mainly near the source area (within 1,500 m of the infiltration beds). Concentrations typically were less than about $0.5 \mathrm{mg} / \mathrm{L}$ (Savoie and LeBlanc, 1998).

Mass was calculated for each horizontally interpolated layer. Total mass then was obtained by summing the results for the layers. The dissolved-phase mass in a horizontally interpolated layer was calculated from

$$
m_{z}=\theta V A \sum_{i=1}^{n} C_{i},
$$

where

$$
\begin{aligned}
& m_{z} \quad \text { is the constituent mass in layer } z \\
& \text { (in kilograms), } \\
& \theta \quad \text { is the aquifer porosity (dimensionless), } \\
& V \quad \text { is the total aquifer volume containing solute } \\
& \text { mass in layer } z \text { (in cubic meters), } \\
& \text { A is a unit conversion factor, } \\
& C_{i} \quad \text { is the interpolated constituent concentration } \\
& \text { for grid cell } i \text { (in milligrams per liter), and } \\
& n \quad \text { is the number of grid cells in layer } z \text {. }
\end{aligned}
$$

Use of this equation assumes that porosity does not vary spatially in the aquifer, and that grid-cell dimensions and layer thickness are uniform. To compute the total aquifer volume containing solute mass for layer $z$, the total plume area in the layer was multiplied by $3 \mathrm{~m}$, the distance between the horizontally interpolated layers. Interpolated concentrations were assumed to be centered in the $3-\mathrm{m}$ vertical interval; for example, concentrations in the $-44.2-\mathrm{m}$ layer represent the -45.7 - to $-42.7-\mathrm{m}$ interval in the aquifer. The total mass then was obtained by summing the masses for the set of horizontal layers that compose the wastewater plume. For mass estimation, interpolated concentrations were computed for $122-\mathrm{m}$ (400-ft) by $122-\mathrm{m}$ (400-ft) grid cells to be consistent with the discretization of the regional model grid. Possibly because of discretization effects, plume-mass results were found to be dependent on the size of grid cell; mass increased by approximately 12 percent as grid-cell length increased from 3 to $152 \mathrm{~m}$.

The above approach is appropriate for calculating mass in the dissolved phase. Mass is calculated from interpolated concentrations, which are assumed to be constant in the pore space of the block of aquifer material surrounding the value. For nitrate and conservative constituents (boron, and chloride), adsorption is negligible and dissolved phase mass is equivalent to total mass. Ammonium, however, undergoes adsorption by cation exchange (Ceazan and others, 1989), and a second equation is required to calculate adsorbed mass. The adsorbed-phase ammonium mass in a horizontally interpolated layer was calculated from

$$
m_{z}=\rho_{b} K_{d} V A \sum_{i=1}^{n} C_{i},
$$

where

$$
\begin{aligned}
& \rho_{b} \quad \begin{array}{l}
\text { is the dry bulk density of aquifer sediment } \\
\text { (grams per cubic centimeter of porous } \\
\text { medium), and }
\end{array} \\
& K_{d} \quad \begin{array}{l}
\text { is the adorption isotherm distribution } \\
\text { coefficient (milliliters per gram of dry } \\
\text { sediment). }
\end{array}
\end{aligned}
$$

Use of this equation assumes that both $K_{d}$ and $\rho_{b}$ do not vary spatially and that dissolved- and adsorbed-phase ammonium are in equilibrium. Dry bulk density was calculated from $\rho_{b}=\rho_{s}(1-\theta)$, where $\rho_{s}$ is the aquifer solid density (in grams per cubic centimeter solid). Using $\rho_{s}=2.65 \mathrm{~g} / \mathrm{cm}^{3}$ for quartz and $\theta=0.35, \rho_{b}=1.72 \mathrm{~g} / \mathrm{cm}^{3}$. The value of the distribution coefficient $\left(K_{d}=0.34 \mathrm{~mL} / \mathrm{g}\right)$ was determined from sediment batch experiments (Ceazan and others, 1989). The ammonium sorption isotherm was linear over an aqueous concentration range that is greater than the range observed in the aquifer.

In 2007, the wastewater plume contained an estimated $118,600 \mathrm{~kg}$ of nitrogen, consisting of $87,000 \mathrm{~kg}$ of nitrate-N and $31,600 \mathrm{~kg}$ of total ammonium-N; $2,900 \mathrm{~kg}$ of boron; and $1,513,500 \mathrm{~kg}$ of chloride (table 1). To estimate changes in plume mass for 1994-2007, mass calculations were done as before except that only the set of wells and MLSs common to both sampling events were used in the analysis (table 1). This reduced the number of sampling sites to 62 for nitrate, ammonium, and boron, and 54 for chloride. The 1994 and 2007 sample datasets developed in this manner were not identical because, although the sampling sites were common to both datasets, the numbers of samples composing the vertical concentration profiles at some of the sites differed by sampling event. Results indicate that the mass of nitrate-N, total ammonium-N, and boron declined by $7.8,37.7$, and 41.3 percent, respectively, between 1994 and 2007 (table 1). In contrast, the mass of chloride increased by 17.9 percent.

One possible explanation for the increase in the mass of chloride is the lateral migration of chloride from upgradient sources (such as road salt) into the wastewater plume under the new groundwater flow conditions that developed near the infiltration beds after cessation of treated-wastewater disposal in 1995. The occurrence of high concentrations of chloride and low concentrations of other wastewater constituents (boron and nitrate) immediately below the infiltration beds is consistent with this explanation (figs. 5B, 7B, and 8B). The decrease in the mass of boron between 1994 and 2007 is not 
Table 1. Mass of nitrate, ammonium, chloride, and boron in the treated-wastewater plume in 1994 and 2007, Ashumet Valley, Cape Cod, Massachusetts.

[kg, kilogram; N, nitrogen; na, not applicable; --, not determined; Common sites are the subset of sampling sites that were sampled for both the 1994 and 2007 snapshots. Plume masses calculated from the common sites were used to compare changes between 1994 and 2007]

\begin{tabular}{|c|c|c|c|c|c|}
\hline \multirow[b]{2}{*}{ Constituent } & \multicolumn{2}{|c|}{ All sites } & \multicolumn{3}{|c|}{ Common sites } \\
\hline & $\begin{array}{l}1994 \text { plume } \\
\text { mass }(\mathrm{kg})\end{array}$ & $\begin{array}{l}2007 \text { plume mass } \\
\text { (kg) }\end{array}$ & $\begin{array}{l}1994 \text { plume mass } \\
\text { (kg) }\end{array}$ & $\begin{array}{l}2007 \text { plume mass } \\
\text { (kg) }\end{array}$ & $\begin{array}{l}\text { Percent change } \\
\text { from } 1994\end{array}$ \\
\hline $\begin{array}{l}\text { Number of sites for nitrate, } \\
\text { ammonium, and boron }\end{array}$ & 70 & 122 & 62 & 62 & na \\
\hline Number of sites for chloride & 62 & 122 & 54 & 54 & na \\
\hline Nitrate-N & 90,000 & 87,000 & 87,700 & 80,900 & -7.8 \\
\hline Total Ammonium-N & 53,400 & 31,600 & 48,000 & 29,900 & -37.7 \\
\hline (Dissolved) & 20,000 & 11,800 & 18,000 & 11,200 & -- \\
\hline (Adsorbed) & 33,400 & 19,800 & 30,000 & 18,700 & -- \\
\hline Boron & 4,800 & 2,900 & 4,600 & 2,700 & -41.3 \\
\hline Chloride & $1,279,300$ & $1,513,500$ & $1,258,300$ & $1,483,700$ & 17.9 \\
\hline
\end{tabular}

well understood. The decreases in the masses of nitrogen species are discussed in greater detail in the Reactive Transport of Nitrogen in the Treated-Wastewater Plume section of this report.

\section{Plume Mass Balance}

The total mass of nitrogen, dissolved organic carbon (DOC), chloride, and boron in the treated wastewater discharged to the aquifer during plant operation (table 2) was estimated by Repert and others (2006) from effluent samples collected between 1974 and 1995 ( $n=3-8$ samples) and the history of effluent discharge rates compiled by Parkhurst and others (2003). Total mass was calculated by multiplying the mean concentration in the effluent by the estimated total volume of water $\left(45 \times 10^{9}\right.$ liters $)$ discharged to the aquifer over the 60 -year period of operation. Calculations of total mass in the treated wastewater based on samples collected only during the last 20 years of operation are considered uncertain because of several factors. Concentrations in effluent were quite variable for most constituents, as indicated by sample standard deviations (table 2). The human population at the MMR and associated wastewater disposal rates varied substantially over 60 years of operation. Based on limited records, disposal rates were probably highest during 1941 to 1945 and 1950 to 1970. Effluent composition during these two periods may have been different than during the later period when the effluent samples were collected. Concentrations of the nitrogen species likely were not constant over time because of changes in treatment-plant operation and flow rates. Ammonium levels may have been higher during the 1940s to 1960s because oxidation of ammonium to nitrate was less likely during this period than during the 1970s and later when wastewater was recycled through the plant, thus increasing the oxidation of ammonium before discharge. In addition, detergent formulations, household and personal-care products, and dietary habits changed over time, possibly affecting concentrations of boron and chloride. Despite the uncertainly, the estimated total mass in the treated effluent was used to conduct a mass balance at the plume scale to gain insight into processes affecting solute mass.

The total nitrogen mass in the treated effluent was calculated as the sum of nitrate- $\mathrm{N}$, nitrite- $\mathrm{N}$, ammonium- $\mathrm{N}$, and organic $\mathrm{N}$. In addition to an estimated $560,000 \mathrm{~kg}$ of nitrate-N and $210,000 \mathrm{~kg}$ of ammonium- $\mathrm{N}$, the wastewater effluent also contained an estimated $154,000 \mathrm{~kg}$ of organic $\mathrm{N}$ and $13,000 \mathrm{~kg}$ of nitrite-N. Thus, approximately $937,000 \mathrm{~kg}$ of total nitrogen was distributed as 59.8 percent nitrate-N, 22.4 percent ammonium-N, 16.4 percent organic $\mathrm{N}$, and 1.4 percent nitrite$\mathrm{N}$ in the treated-wastewater effluent. Comparison of tables 1 and 2 indicates that the masses of nitrate- $\mathrm{N}$ and ammonium-N in the 2007 plume were about 15 percent of the estimated total masses in wastewater effluent released to the aquifer. However, biotransformation of the organic $\mathrm{N}$ may have produced additional ammonium and possibly nitrate in the aquifer after recharge. Smith and Duff (1988) concluded that because soil water and shallow groundwater had the same concentrations of nitrate and ammonium as the effluent, biological processes were not having an observable effect on these species in the unsaturated zone. This is consistent with the high effluent flow rates and relatively thin unsaturated zone $(6 \mathrm{~m})$ beneath the infiltration beds, which results in a relatively short residence time the unsaturated zone. If assimilation of nitrogen in biomass is neglected and all organic $\mathrm{N}$ in the effluent was transformed to ammonium, then total ammonium mass 
Table 2. Mean concentration and total mass of selected constituents in treated wastewater discharged from1936 to 1995 from the Massachusetts Military Reservation treatment plant, Ashumet Valley, Cape Cod, Massachusetts.

[mg/L, milligrams per liter; kg, kilograms; N, nitrogen; --, not available; Mean wastewater concentration based on 3 to 8 samples. Concentration data from D.A. Repert, U.S. Geological Survey, written commun., 2010]

\begin{tabular}{|c|c|c|c|c|}
\hline \multirow[b]{2}{*}{ Constituent } & \multicolumn{3}{|c|}{ Treated wastewater concentration (mg/L) } & \multirow[b]{2}{*}{$\begin{array}{c}\text { Total mass in treated } \\
\text { wastewater, 1936-1995 } \\
(\mathrm{kg})\end{array}$} \\
\hline & Mean & $\begin{array}{l}\text { Standard } \\
\text { deviation }\end{array}$ & $\begin{array}{l}\text { Number of } \\
\text { samples }\end{array}$ & \\
\hline Nitrate-N & 12.2 & 5.4 & 8 & 560,000 \\
\hline Ammonium-N & 4.6 & 3.7 & 8 & 210,000 \\
\hline Boron & 0.45 & 0.097 & 5 & 20,000 \\
\hline Chloride & 39 & 10.1 & 4 & $1,760,000$ \\
\hline Nitrite-N & 0.30 & 0.20 & 7 & 13,000 \\
\hline Organic-N & 3.4 & 1.9 & 3 & 154,000 \\
\hline Dissolved organic carbon & 13.3 & 5.9 & 5 & 603,000 \\
\hline Specific conductance & $407^{1}$ & 64.7 & 5 & -- \\
\hline
\end{tabular}

${ }^{1}$ Specific conductance units in microsiemens per centimeter at 25 degrees Celsius.

released to the aquifer over 60 years of operation would be $364,000 \mathrm{~kg}$ and the mass of ammonium- $\mathrm{N}$ in the plume in 2007 plume could be as low as 9 percent of the total organic $\mathrm{N}$ and ammonium-N mass that was discharged to the aquifer.

The masses of boron and chloride in the 2007 plume were 14.5 and 86.0 percent, respectively, of total estimated masses in wastewater effluent. One possible explanation for the apparent large loss of boron, which is presumed to be conservative in the outwash aquifer (Barber and others, 1988; Repert and others, 2006), is that the total estimated mass in the wastewater effluent is uncertain, as discussed above. Alternatively, boron may have been attenuated by an unknown reaction, an explanation which also is consistent with the apparent boron mass loss between 1994 and 2007 (table 1).

A general mass-balance equation for any constituent in the wastewater plume expressed in terms of the mass in the aquifer is

$$
m_{a}=m_{e}+m_{p r}-m_{r}
$$

where

$$
\begin{gathered}
m_{a} \quad \begin{array}{c}
\text { is the total mass in aquifer (adsorbed plus } \\
\text { dissolved), }
\end{array} \\
m_{e} \quad \text { is the mass input to the aquifer from the } \\
\text { wastewater effluent, } \\
m_{p r} \quad \begin{array}{c}
\text { is the mass produced in the aquifer by } \\
\text { reaction, and }
\end{array} \\
m_{r} \quad \text { is the mass removed from the aquifer by } \\
\quad \text { reactions, pumping, and discharge. }
\end{gathered}
$$

The $m_{r}$ term expanded to represent losses from physical processes and reactions is

$$
m_{r}=m_{l r}+m_{w}+m_{p}+m_{c}
$$

where

$$
\begin{gathered}
m_{l r} \quad \begin{array}{c}
\text { is the mass removed from the aquifer by } \\
\text { reactions, }
\end{array} \\
m_{w} \quad \text { is the mass removed by pumping wells, } \\
m_{p} \quad \text { is the mass removed by discharge to ponds } \\
\text { (mainly Ashumet Pond), and } \\
m_{c} \quad \text { is the mass removed by discharge to all other } \\
\text { groundwater discharge areas (rivers and } \\
\text { coastal embayments). }
\end{gathered}
$$

Losses to Ashumet Pond $\left(m_{p}\right)$ are treated separately because a part of the plume has been discharging to Ashumet Pond for decades. In contrast, it appears that relatively little mass has discharged to downgradient discharge areas $\left(m_{c}\right)$. Based on locations of known irrigation and remediation withdrawals, it also appears likely that the plume has been largely unaffected by major withdrawals $\left(m_{w}\right)$ over the seven-decade residence time in the aquifer. To develop simplified mass balance equations for the 2007 plume, $m_{c}$ and $m_{w}$ are assumed to be negligible. For conservative species such as chloride and boron, reactions can be omitted, and the simplified mass-balance equation is

$$
m_{a}=m_{e}-m_{p}
$$

For reactive constituents such as ammonium and nitrate, the simplified mass-balance equation is

$$
m_{a}=m_{e}+m_{p r}-m_{l r}-m_{p} .
$$

Determining net mass loss in the wastewater plume is complex because nitrate and ammonium are involved in multiple, coupled reactions (see Reactive Transport of Nitrogen in the Treated-Wastewater Plume section). 
Although the mass-balance approach provides a useful conceptual framework for determining the fate of nitrogen in the wastewater plume, most of the terms in the equations are either unknown or known with a high degree of uncertainty. Plume mass in 2007 is the best-known quantity. Mass input to the aquifer from wastewater effluent, mass discharged to Ashumet Pond, and mass produced and consumed in the aquifer are the least well understood components of the massbalance equation at the spatial (plume) and temporal (71-year) scales for this study. The mass flux to Ashumet Pond appears to be highly sensitive to the loading history of the disposal beds and groundwater-flow system near the pond (LeBlanc, 1984b; Parkhurst and others, 2003). The flux can be computed with a groundwater flow model, but large uncertainties associated with the flow system and the loading of the wastewater beds will propagate to the flux estimate. The total mass of nitrogen produced or consumed by reactions at the plume scale probably cannot be reliably estimated for the entire period of operation of the treatment plant. For the coastal nitrogen loading analysis, however, a transient analysis of plume evolution and mass balance is not necessary. Rather, in this study, a steady-state model was used to transport the nitrogen known to be in the aquifer in 2007 to the coastal discharge areas without quantification of prior mass loss. Nonreactive transport (that is, no mass loss in the aquifer) provides an upper-end estimate of the amount of nitrogen discharge from the plume to the coast in the years following 2007.

\section{Reactive Transport of Nitrogen in the Treated- Wastewater Plume}

Previous field and laboratory studies and the 1994 and 2007 snapshot datasets were evaluated to develop conceptual models for reactive transport of nitrogen in the aquifer and determine the representativeness of the nonreactive-transport simulations used in this study. If the post-cessation reactivity of nitrogen is low, then most of the mass in the aquifer (in 2007) will reach discharge areas, and nonreactive-transport simulations will provide a reasonable estimate of nitrogen loading. On the other hand, if mass loss during transport to discharge areas is more substantial, then the nonreactivetransport simulations will overestimate nitrogen loading and provide a worst case estimate. Comparison of the 1994 and 2007 datasets also allows for an evaluation of biogeochemical changes that have taken place since cessation of treated-wastewater disposal in 1995.

Determining net mass loss in the treated-wastewater plume is complex because nitrate and ammonium may be involved in multiple, coupled reactions. Nitrate is potentially consumed by heterotrophic denitrification, autotrophic denitrification coupled to oxidation of reduced inorganic species (Korom, 1992), dissimilatory nitrate reduction to ammonium (DNRA), and anammox. Nitrate is potentially produced by nitrification. Ammonium is potentially consumed by nitrification and anammox and produced by ammonification of organic N. Anammox is a recently identified reaction in which ammonium is oxidized to nitrogen gas under anaerobic conditions (Mulder and others, 1995). Ammonium serves as the electron donor and nitrate or nitrite as the electron acceptors. Anammox was first identified in wastewater systems (Mulder and others, 1995; Jetten and others, 2001), and has since been observed in estuarine sediments (Rich and others, 2008), soils (Jetten, 1999) and groundwater (Clarke and others, 2008; Robertson and others, 2012).

\section{Nitrate}

Denitrification, the microbially mediated reduction of nitrate to nitrogen gas under anoxic conditions, is the most important reaction potentially affecting nitrate at the plume scale. DNRA has also been observed, but the reaction had only a small effect on nitrate transport relative to denitrification (Smith and others, 1991). Autotrophic denitrification potentially can occur, but the highly reducing conditions needed for the production of electron donors such as hydrogen gas, reduced iron, and sulfur do not appear to be prevalent at the plume scale. Recent studies have shown that anammox also occurs in the plume (R.L. Smith, U.S. Geological Survey, written commun., 2012). Thus, the potential exists for simultaneous conversion of nitrate and ammonium to nitrogen gas where these species co-occur, but the importance of the reaction at the plume scale is unclear.

The occurrence of denitrification within $300 \mathrm{~m}$ of the infiltration beds has been demonstrated in the laboratory and field (Smith and Duff, 1988; Smith and others, 1991; Smith and others, 1996; Smith and others, 2004). Because denitrifying bacteria commonly are heterotrophic and couple the oxidation of organic carbon to the reduction of nitrate to obtain energy for growth, the spatial distribution of the occurrence and rate of denitrification may be determined by the amount and quality of the DOC in the plume. Previous studies have shown that biodegradation of the labile organic carbon in the wastewater effluent occurred predominantly near the infiltration beds (within about $500 \mathrm{~m}$ ), and that the organic compounds that serve as the electron donors for denitrification are increasingly recalcitrant with distance from the infiltration beds (Harvey and others, 1984; Thurman and others, 1986; Barber, 1992; Harvey and Barber, 1992). For example, Thurman and others (1986) estimated that only 15 to 30 percent of the DOC originally in the effluent was present in downgradient parts of the plume. Moreover, about 50 percent of the remaining DOC was composed of nonbiodegradable alkylbenzene sulfonate (ABS) detergent. A comparison of effluent DOC concentrations with groundwater DOC concentrations near the infiltration beds also provides evidence for rapid uptake (biodegradation or sorption) of labile DOC. Before cessation of wastewater disposal, concentrations of DOC rarely exceeded about $4 \mathrm{mg} / \mathrm{L}$ near the infiltration beds (Harvey and Barber, 1992; Savoie and LeBlanc, 1998). In contrast, effluent DOC was about $12 \mathrm{mg} / \mathrm{L}$ (and possibly up to $20-25 \mathrm{mg} / \mathrm{L}$ in the past), suggesting that most of the DOC in the effluent 
had been biodegraded in the unsaturated zone and groundwater adjacent to the beds, or most of the DOC was adsorbed to aquifer solids. In addition, Harvey and others (1984) and Harvey and Barber (1992) showed that the abundance of free-living bacteria and heterotrophic activity decreased with increasing distance from the infiltration beds, and these trends were attributed to the increasing recalcitrance of the wastewater-derived DOC in the plume. Based on the composition and spatial patterns of DOC and the distribution and abundance of bacterial biomass, denitrification may be electron donor (DOC and reduced inorganic constituents) limited in most of the treated-wastewater plume.

A comparison of longitudinal nitrate distributions within the mapped plume along section $Z-Z^{\prime}$ before and after cessation of wastewater disposal also supports a conceptual model in which the rate of nitrate loss is very low or negligible beyond a reactive zone near the infiltration beds (fig. 9). In 1994, during active wastewater disposal, nitrate concentrations were relatively high (ranging from 0 to nearly $30 \mathrm{mg} / \mathrm{L}-\mathrm{N}$ ) within $1,000 \mathrm{~m}$ of the infiltration beds (fig. 9). Within this same interval, specific conductance ranged from about 50 to $550 \mu \mathrm{S} / \mathrm{cm}$, and there was a weak linear relation between nitrate and specific conductance $\left(\mathrm{R}^{2}=0.57 ; \mathrm{p}<0.001\right.$; fig. 9A). In contrast, in the 1,000 to $6,500 \mathrm{~m}$ interval, nitrate concentrations in the plume were substantially less variable, ranging from about 1 to $4 \mathrm{mg} / \mathrm{L}-\mathrm{N}$, with a modest decrease in concentration with distance from the infiltration beds (fig. 9B). In 2007, 12 years after cessation of wastewater disposal, specific conductance and nitrate concentrations were low in the 0 to $1,000-\mathrm{m}$ interval, and nitrate concentrations in this interval were similar to concentrations in downgradient parts of the plume (fig. 9). These longitudinal patterns indicate that, during active wastewater disposal, high nitrate concentrations (and labile DOC) were being injected into the aquifer and that nitrate was being reduced within a reactive zone that extended roughly $1,000 \mathrm{~m}$ downgradient from the infiltration beds to a residual concentration of 1 to $4 \mathrm{mg} / \mathrm{L}-\mathrm{N}$. Perhaps because the DOC was too recalcitrant to support continued denitrification, nitrate concentrations declined relatively little beyond the reactive zone. The most extensive denitrification in the reactive zone was in the core of the plume, leaving a shell of relatively elevated nitrate in the mixing zone at the plume boundaries (LeBlanc, 1984a; Repert and others, 2006). By 2007, however, labile DOC and nitrate were no longer being discharged to the aquifer, and ongoing losses with distance from the source were not evident. Wastewater-derived DOC and nitrate had been transported roughly $1,300 \mathrm{~m}$ downgradient from the wastewater infiltration beds ( 12 years of flow at a horizontal groundwater flow velocity of $0.3 \mathrm{~m} / \mathrm{yr}$ ), and the nitrate in the 0 - to $1,000-\mathrm{m}$ interval probably was generated from oxidation of adsorbed ammonium and organic $\mathrm{N}$ near the beds (Repert and others, 2006).

To further evaluate spatial trends in the nitrate concentration data, the conservative-tracer method of Kroeger and others (2006b) also was applied to the data along the $Z-Z^{\prime}$ transect. Mean specific conductance and nitrate concentrations in the effluent and background groundwater were used to correct for dilution before calculating percent nitrate loss in the plume. Results from this method show that losses of nitrate in samples from near the leading edge of the plume ranged from 60 to 80 percent in comparison to effluent; however, most samples from close to the source had percent losses similar to samples from farther downgradient, so that there was no clear trend of ongoing loss as nitrate migrated downgradient (data not shown). Results from this method were consistent with the 2007 nitrate concentration data on the $Z-Z^{\prime}$ transect (fig. 9).

Because by 2007 nitrate concentrations throughout the plume were low and ongoing losses with distance from the source were not evident, it is reasonable to expect that the entire mass of nitrate in the 2007 plume will be transported to discharge areas. However, studies to measure denitrifying activity in distal parts of the plume have not been conducted; a low rate of ongoing denitrification or other nitrate removal reaction could have an appreciable effect on plume-scale nitrate loading to the coast because traveltimes range from decades to hundreds of years. Another possible location for mass loss is the groundwater/surface-water interface at the discharge location, where lithologic and geochemical changes occur (Böhlke and Denver, 1995; Kroeger and Charette, 2008). In this study, losses at the interface were not considered.

\section{Ammonium}

Nitrification, the microbially mediated oxidation of ammonium to nitrate in the presence of dissolved oxygen, appears to be the most important reaction affecting ammonium at the plume scale. Previous work at the site has demonstrated that nitrification occurs in the mixing zone at the upper boundary of the wastewater plume where both dissolved oxygen and ammonium are present (Böhlke and others, 2006; Smith and others, 2006; Miller and Smith, 2009). Ammonium loss in the anoxic core of the ammonium plume has not been observed. Because vertical transverse dispersion is a weak mixing process (Sudicky, 1986; Garabedian, and others, 1991), the rate of nitrification at the upper boundary is limited by the vertical transport of dissolved oxygen into the mixing zone, and consequently is less than the potential maximum rate for the microbial community in the aquifer (Böhlke and others, 2006; Smith and others, 2006). On the basis of the limited size of the nitrification zone and low rate of reaction, relatively little ammonium is consumed by nitrification along the upper boundary of the plume. Previous work has also shown that geochemical changes resulting from cessation of wastewater disposal, in particular depletion of immobile electron donors and eventual downgradient migration of a dissolved oxygen front, may play an important role in determining the fate of the ammonium plume (Böhlke and others, 2006). If oxygen demand from the mass of immobile electron donors (reduced metals, organic carbon, and ammonium) in the aquifer was persistent, then the downgradient migration of the dissolved oxygen front would be slow relative to groundwater flow. 

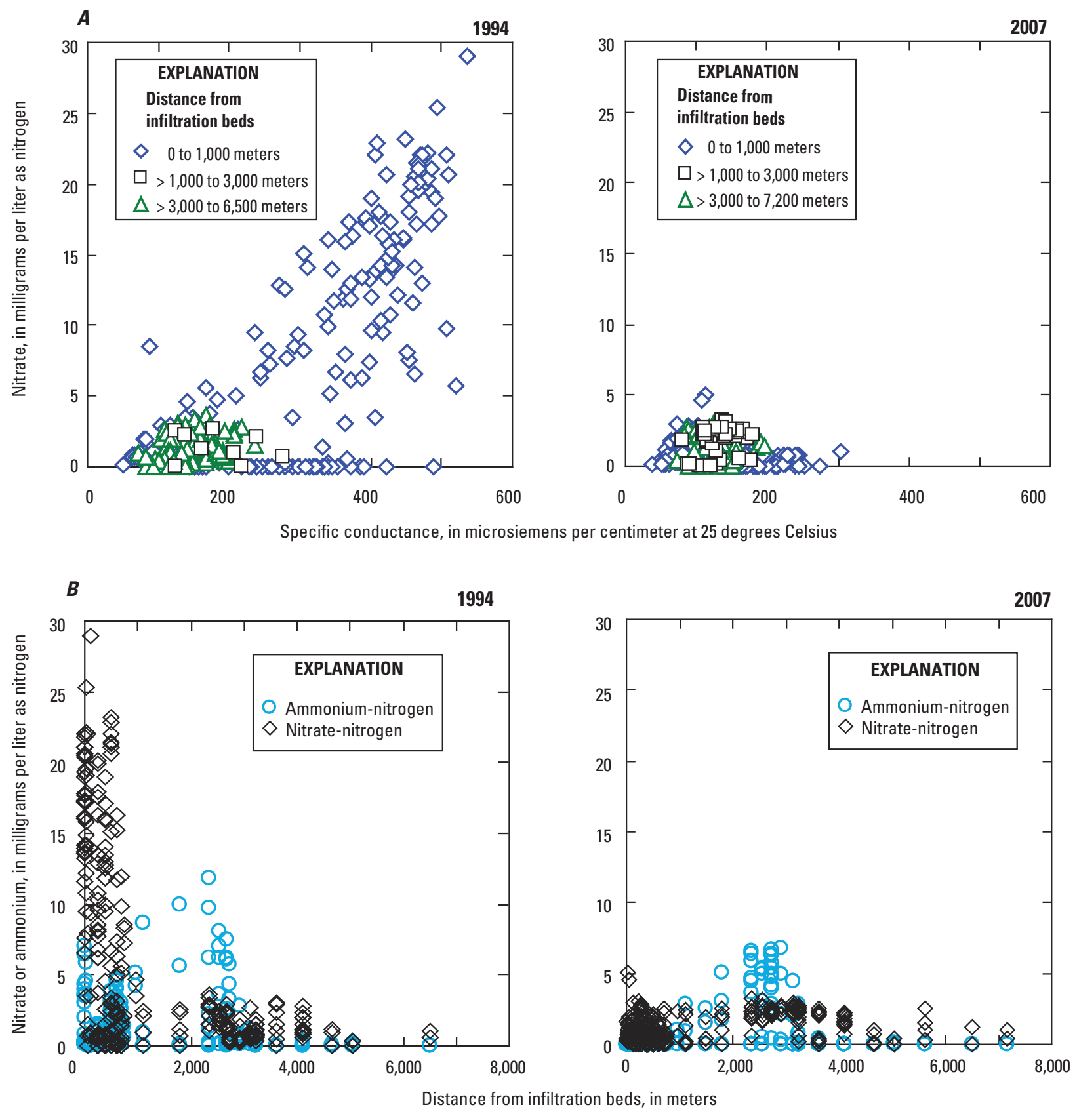

Figure 9. Concentrations of $A$, nitrate compared to specific conductance, and $B$, nitrate and ammonium compared to distance on section Z-Z' in 1994 and 2007, Ashumet Valley, Cape Cod, Massachusetts. Location of section Z-Z' shown on figure 2. 
Alternatively, if the oxygen demand was not persistent, then the dissolved oxygen front would begin migrating conservatively and eventually reach the back end of the ammonium plume. Extensive data collection near the infiltration beds indicates that oxygen demand in the core of the plume substantially slows the migration of the dissolved oxygen front. For example, by 2004, 9 years after cessation, the dissolved-oxygen front had not migrated far and remained near the downgradient edge of the disposal beds (Repert and others, 2006); consequently, lateral advection of dissolved oxygen into the slower moving ammonium plume was not occurring at this location. Taken together, previous studies and data collection indicate that ammonium loss has been minor in comparison to the total mass of ammonium in the plume.

In contrast, estimates of ammonium mass loss and changes in the distribution of ammonium and dissolved oxygen in the aquifer from evaluation of the 1994 and 2007 plume snapshot data indicate that reoxygenation of the aquifer and ammonium mass loss are more extensive. As discussed previously, these plume-scale datasets indicate an apparent ammonium-N mass loss of 37.7 percent between 1994 and 2007 , or from 48,000 to $29,900 \mathrm{~kg}$ (table 1). This change corresponds to a zero-order (constant) rate of $1,400 \mathrm{~kg} / \mathrm{yr}$ of total (adsorbed plus dissolved) ammonium-N. If this rate of loss were to continue, then the ammonium plume would persist for only 22 years and fail to reach a discharge boundary before complete removal from the aquifer. Assuming that such a large difference in plume mass is unlikely to be an artifact of the plume-mapping methodology or analytical differences between sampling events, post-cessation ammonium loss may be more extensive than previously recognized from analyses of more spatially limited datasets.

A scatterplot of samples from within the mapped plume boundaries, analyzed in both 1994 and $2007(\mathrm{n}=356)$, demonstrates that the most extensive change in ammonium concentrations occurred in the back of the plume, nearest the infiltration beds (fig. 10A). Ammonium concentrations decreased at the back end of the plume $(0-800 \mathrm{~m})$, were roughly equivalent in the body of the plume $(800-2,800 \mathrm{~m})$, and increased at the leading edge of the plume $(2,800-3,200 \mathrm{~m})$. This spatial pattern is consistent with the downgradient movement of the plume; however, the measured decrease in plume mass between 1994 and 2007 indicates that mass loss has occurred in addition to simple displacement. Of the 235 samples in the 0 - to $800-\mathrm{m}$ interval that had ammonium concentrations of $0.1 \mathrm{mg} / \mathrm{L}-\mathrm{N}$ (10 times the detection limit) or greater in 1994, 100 percent had lower concentrations in 2007 than in 1994. In addition, a plot of the difference in dissolved oxygen concentration with distance from the infiltration beds (samples were projected perpendicularly onto the plume centerline to determine distance from the beds) for the same dataset of sample pairs shows that dissolved oxygen concentrations in the 0- to 800-m interval increased between 1994 and 2007 (fig. 10B). Dissolved oxygen concentrations in 2007 were equal to or greater than 1994 concentrations in 64 percent of the sample pairs $(n=269)$ in this spatial interval, and in
31 percent of pairs $(n=87)$ farther downgradient in the plume. Increases in dissolved oxygen concentration at the leading edge of the plume (3,300 $\mathrm{m}$ from source, fig. 10B) may be due in part to reinjection of oxygenated water from the chlorinated-solvent remedial system that began operation in 1999 (Air Force Center for Engineering and the Environment, 2010). The system discharged treated water to two shallow infiltration trenches near the ends of section $E-E^{\prime}$. Dissolved oxygen concentrations changed least and remained low in the core of the plume near the infiltration beds (data not shown). Plan-view distributions of the ammonium plume at selected depths also show a pattern of change between 1994 and 2007 that is consistent with the scatter plots (fig. 11). Between 1994 and 2007, the ammonium plume decreased in size between the infiltration beds and Ashumet Pond (fig. 11). Concentrations of ammonium in the interior of the plume (for example, in the thin, high-concentration layer at $-7.6 \mathrm{~m}$ ) also decreased, but the largest change in the plume was at the margins, where the plume width decreased at most depths. One possible explanation for these observations is that post-cessation downgradient migration of oxygenated groundwater provided appropriate conditions for nitrification in the back (excluding the core of the plume) and sides of the plume in addition to along the upper boundary.

Although the change in plume mass and spatial patterns in ammonium and dissolved oxygen concentrations are suggestive of ammonium oxidation during 1994 to 2007, these data do not provide direct evidence for widespread nitrification in the wastewater plume. Moreover, the nitrate-N mass that would have been produced by nitrification of $18,100 \mathrm{~kg}$ of ammonium-N was not evident in the difference between the 1994 and 2007 nitrate plume mass estimates (table 1) or the nitrate concentrations along section $Z-Z^{\prime}$ (fig. 9B), which likely would have been elevated near the ammonium plume. Another possible reaction that may account for some of the apparent ammonium mass loss is anammox; in this case, both nitrate and ammonium would be consumed, and nitrate losses from anammox could partially offset nitrate gains from nitrification. The possible occurrence of multiple nitrogen producing and consuming reactions in different parts of the plume and at different times following cessation of wastewater disposal makes it difficult to determine the net effect of ammonium oxidation on the mass of nitrate. In addition, error related to plume-mapping procedures could have affected the calculation of nitrate- $\mathrm{N}$ and ammonium-N mass in the plume and the resulting differences in mass between 1994 and 2007. An additional plume snapshot for nitrogen species, DOC, dissolved oxygen, chloride, boron, and $\mathrm{pH}$ (nitrification and anammox produce acidity) within approximately 10 years from 2007 would be useful for evaluating changes in nitrogen mass at the plume scale and developing a better understanding of the reactions responsible for the observed changes. 

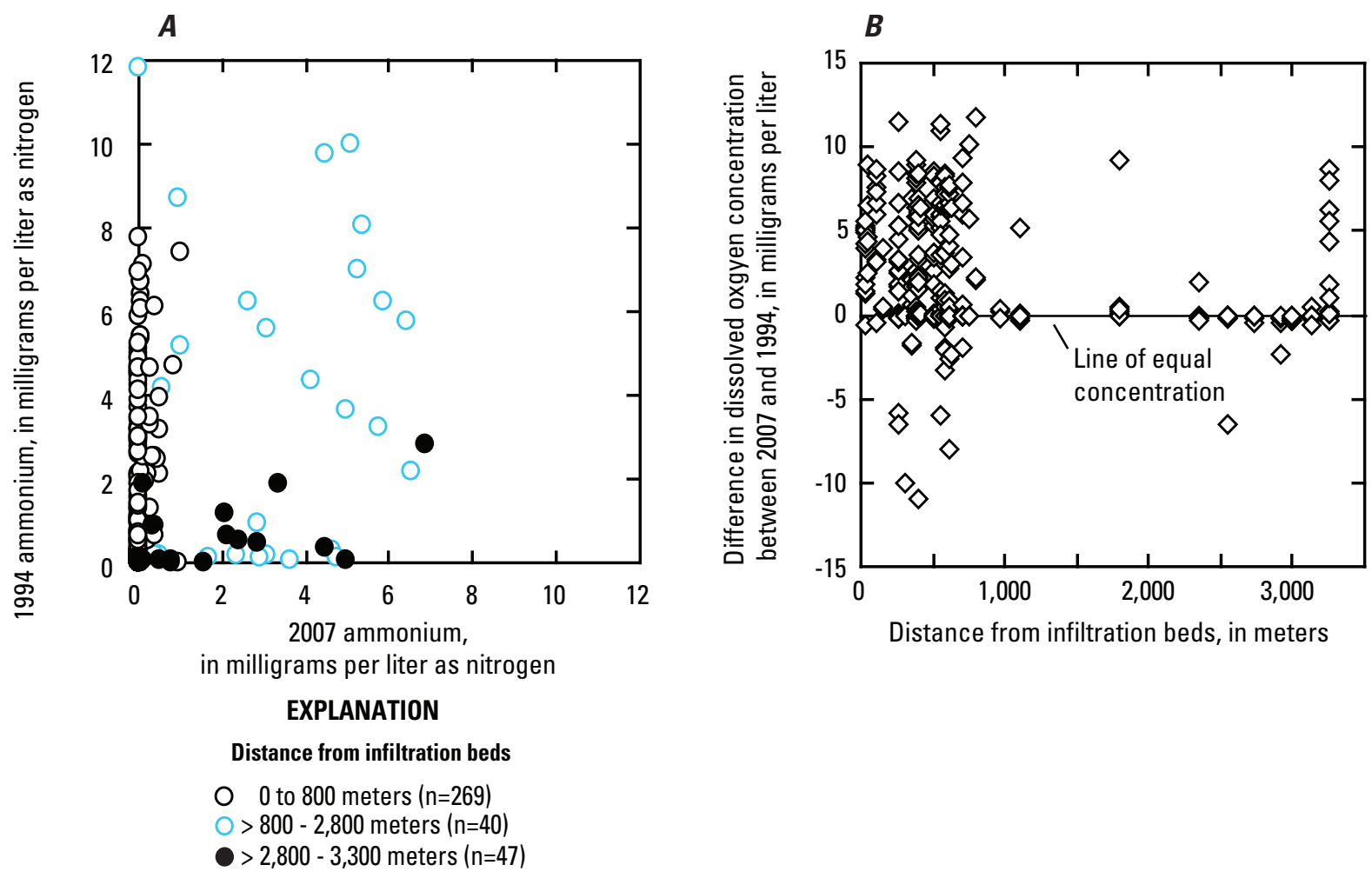

Figure 10. $A$, ammonium concentration in 1994 compared to ammonium concentration in 2007, and $B$, difference in dissolved oxygen concentration between 1994 and 2007 in relation to distance from the infiltration beds for the set of groundwater samples (number of samples $(n)=356$ ) analyzed for ammonium in 1994 and 2007, Ashumet Valley, Cape Cod, Massachusetts.

\section{Simulation of Nitrogen Transport}

Walter (2013) modified an existing regional model of western Cape Cod (Walter and Whealan, 2005) to conduct an analysis of nitrogen transport from surficial sources to ecological receptors in coastal areas on western Cape Cod. Because the scope of Walter (2013) is similar to the scope of this study and considers the same regional area, the Walter (2013) model was used to simulate the advective transport of nitrogen in the treated-wastewater plume to coastal discharge areas. To simulate the transport of plume nitrogen, additional modifications were made to the Walter (2013) model, including linearization of the model by converting water-table layers to confined layers, addition of layers to accommodate the gridded plume, and alteration of pumping rates and recharge. The "base" version of the regional model and the associated analyses are fully documented in Walter (2013); a synopsis of the development of this model is given below.

Groundwater flow was simulated by using the finitedifference model MODFLOW-2005 (Harbaugh, 2005). The USGS particle-tracking software program MODPATH was used to simulate the advective transport of nitrogen in the aquifer (Pollock, 1994). The USGS software application MODTOOLS (Orzol, 1997) was used to convert model output to georeferenced data layers.

\section{Regional Model Design}

The regional model encompasses the entire western end of Cape Cod (Walter, 2013). The model grid has 246 rows and 365 columns with a uniform horizontal discretization

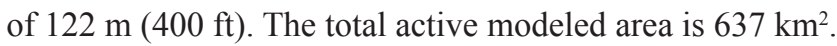
The modified regional model has 27 layers with thicknesses ranging from less than $3 \mathrm{~m} \mathrm{(10} \mathrm{ft)} \mathrm{above} \mathrm{sea} \mathrm{level} \mathrm{in} \mathrm{parts} \mathrm{of}$ the aquifer to more than $30 \mathrm{~m}(100 \mathrm{ft})$ in the deepest part of the aquifer.

Coastal embayments, open coastal water, and rivers and streams are represented as head-dependent flux boundaries in the model. The General Head Boundary (GHB) and Drain (DRN) packages of MODFLOW-2000 (Harbaugh and others, 2000; McDonald and Harbaugh, 1988) were used to simulate the open coastal waters, coastal embayments (saltwater estuaries), and some of the freshwater wetlands in the model domain. The Streamflow Routing Package (STR; Prudic, 1989) was used to simulate other freshwater wetlands and streams; this package allows for an accounting of streamflow generated from groundwater discharge and for pumpinginduced streamflow depletion. Freshwater ponds were simulated as regions of high hydraulic conductivity $(30,500 \mathrm{~m} / \mathrm{d})$ within the model and, as a result, groundwater flows through ponds under steady-state conditions. 
A. 1994

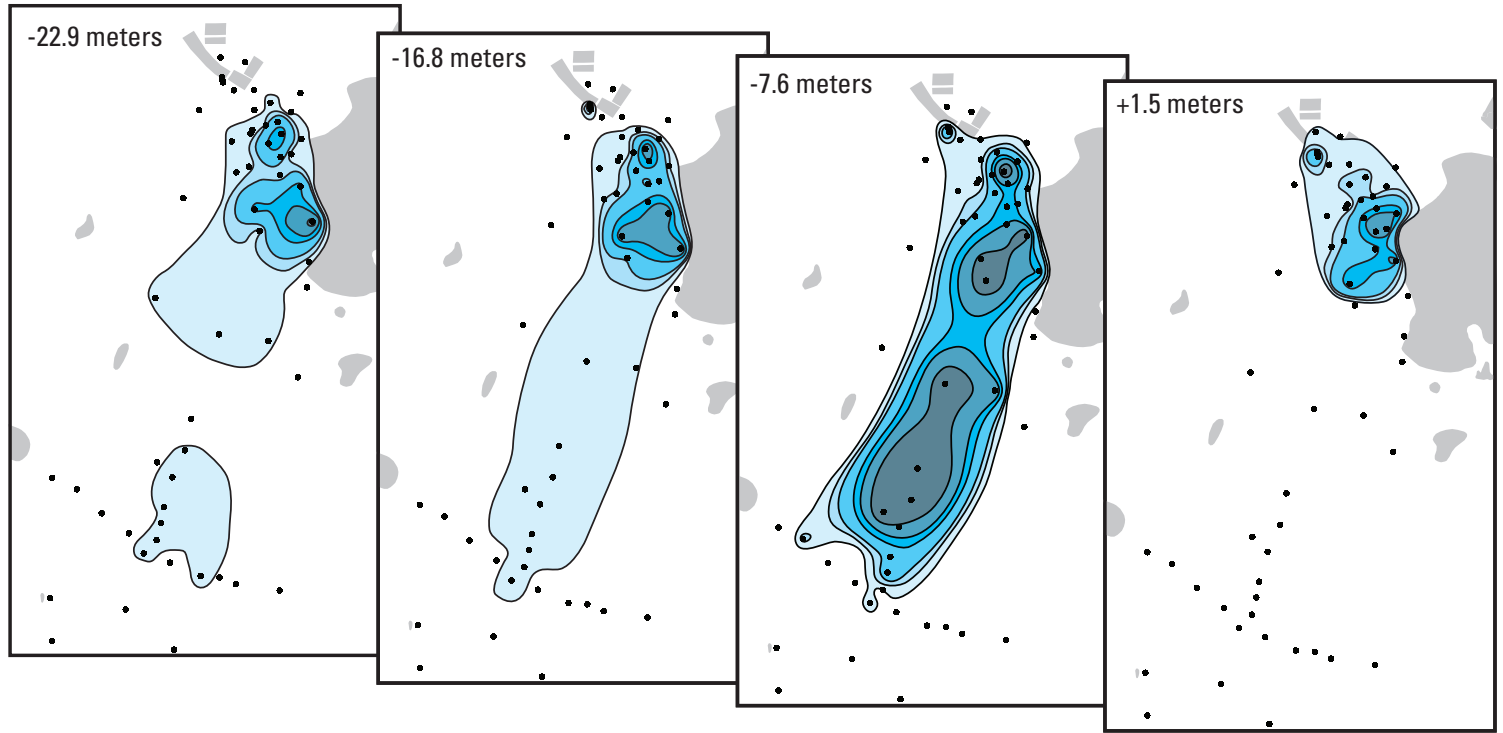

B. 2007

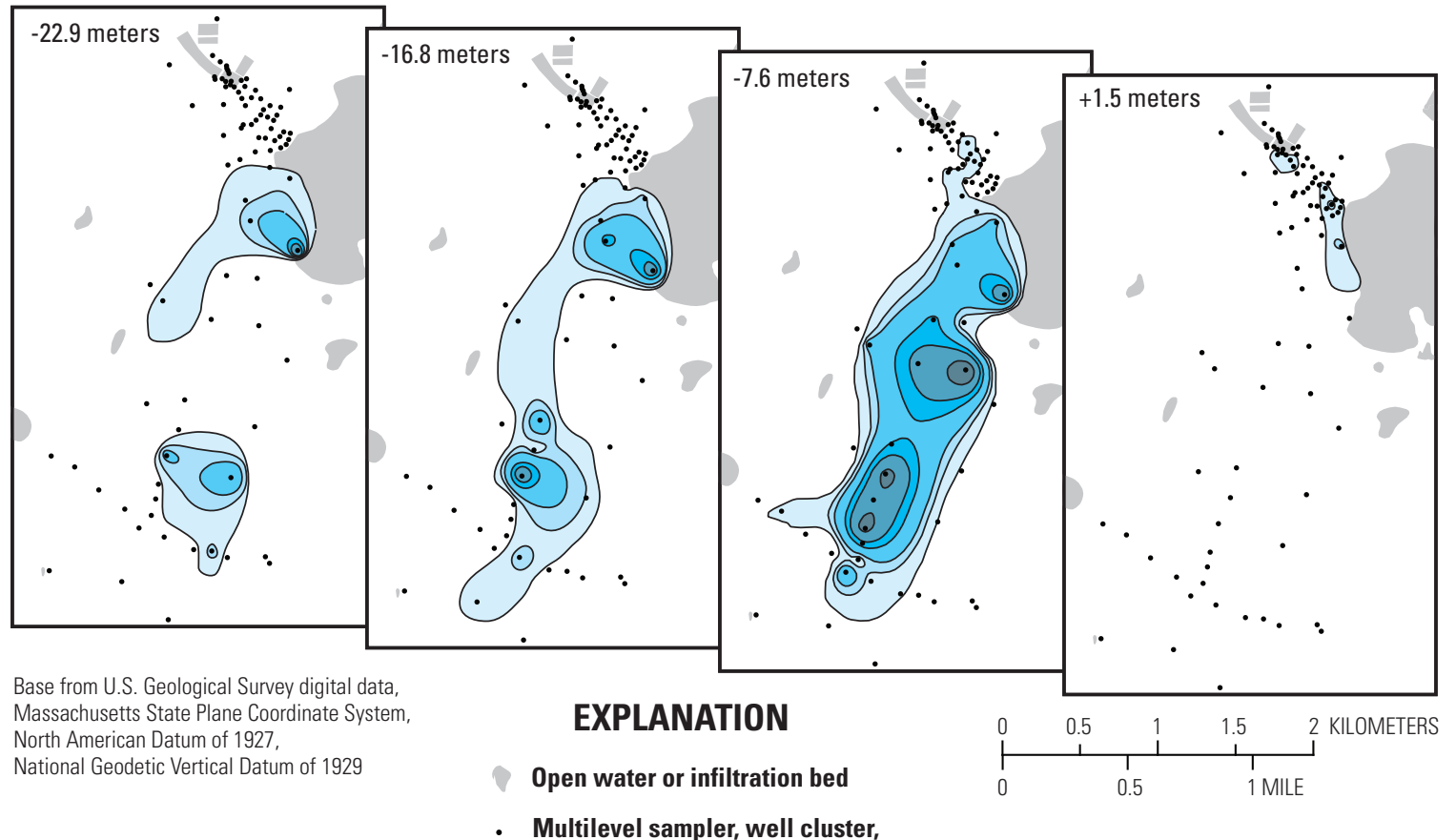

Multilevel sampler, well cluster, or direct-push boring site

Ammonium concentration,

in milligrams per liter as nitrogen

$\square \quad 0.0$ to $0.4 \square>2.0$ to 2.8

$\square>0.4$ to $0.8 \square>2.8$ to 4.4

$>0.8$ to $2.0 \square>4.4$

Figure 11. Distribution of ammonium in A, 1994 and B, 2007 at altitudes of $-22.9,-16.8,-7.6$, and +1.5 meters, Ashumet Valley, Cape Cod, Massachusetts. 
Aquifer properties were estimated from lithologic logs, aquifer tests, and a depositional model of western Cape Cod (Masterson and others, 1997; Byron Stone, U.S. Geological Survey, written commun., 2002). Hydraulic conductivity varies spatially within layers and with depth and ranges from $107 \mathrm{~m} / \mathrm{d}$ for sand and gravel to $3 \mathrm{~m} / \mathrm{d}$ for silt and clay. Hydraulic conductivity in the Mashpee pitted plain outwash sediments generally decreases to the south and with depth (Walter and Whealan, 2005).

Recharge, which is the only source of water to the aquifer, was applied to the aquifer at a constant rate of $0.68 \mathrm{~m} / \mathrm{yr}$, a value derived from a long-term record of precipitation and temperature at Hatchville, Mass., and adjusted during model calibration (Walter and Whealan, 2005). Net recharge to ponds was $0.41 \mathrm{~m} / \mathrm{yr}$ after accounting for pan evaporation (Farnsworth and others, 1982), and recharge to wetlands was zero because these areas function as net discharge areas in the groundwater-flow system. Recharge to the aquifer was adjusted further to account for septic-system return flow in unsewered residential areas that receive water from publicsupply systems and for point discharges of wastewater at existing wastewater treatment plants. Withdrawals of water from production wells totaling about 17.3 million gallons per day (Mgal/d) were simulated by use of the Well (WEL) package (McDonald and Harbaugh, 1988). One production well (Fresh Pond well) is near the observed path of the plume (fig. 12). The steady-state pumping rate of the well, as represented in the regional model, is about $0.6 \mathrm{Mgal} / \mathrm{d}$.

The regional steady-state flow model was calibrated by adjusting initial estimates of recharge and aquifer properties to achieve an acceptable match between observed and simulated heads and streamflow. Details of the development, calibration, and limitations of the regional model are provided by Walter (2013).

\section{Mass-Loaded Particle Tracking}

Particle tracking was used to simulate the advective transport of nitrogen in the treated-wastewater plume to discharge areas along the coast. The particle-tracking algorithm in MODPATH uses model-calculated cell-by-cell flows to track the movement of particles of water through the aquifer. Particle tracking represents advective transport only. Other processes that can affect solute migration in groundwaternamely dispersion, adsorption, and reactions - are not explicitly accounted for in a particle-tracking analysis. Neglecting these processes affects mass-loading estimates to discharge areas in different ways. Dispersion is a mechanical mixing process that spreads solute mass in transverse and longitudinal directions relative to the flow direction, thereby lowering concentrations at the plume margins. However, because dispersive mixing transverse to the direction of groundwater flow is a relatively weak process and longitudinal mixing only affects the leading and trailing edges of the plume, dispersion likely has only a minimal effect on the concentration and timing of nitrogen reaching a given receptor and, therefore, on the nitrogen load calculated by a particle-tracking analysis (Walter, 2007). Reversible adsorption, a process that affects ammonium, slows the rate of solute migration compared to the rate of groundwater flow. In contrast, nonsorbing species, such as nitrate, move at the same rate as groundwater. Neglecting adsorption in a particle-tracking analysis will affect the timing of mass loading (the solute will arrive at the receptor too quickly in the simulations), but total mass will be conserved. Biologically mediated mass loss of nitrogen in the aquifer potentially is the most consequential process. If nitrogen is biodegraded in the aquifer, then mass-loading rates calculated by a particle-tracking analysis would overestimate true massloading rates and represent a worst case scenario. Overall, the use of particle tracking to simulate nitrogen loading to coastal receptors is most appropriate for nonsorbing, nonreactive species such as nitrate; however, particle tracking also can be used to simulate the migration of a species such as ammonium that is affected by reversible adsorption.

The movement and discharge of nitrogen in the treatedwastewater plume were quantified by assigning a particle to each model cell that contained a nonzero interpolated concentration from the gridded plume. The number of particles released from the nitrate and ammonium plumes were 6,169 and 695, respectively. Particles from the plumes then were transported to discharge areas under steady-state flow conditions. Separate simulations were conducted for nitrate and ammonium. Once a particle reached a surface-water discharge area, it was removed from the model domain. For the flow-through kettle ponds, this is equivalent to assuming that the nitrogen undergoes rapid uptake in the ponds and, consequently, does not reenter the aquifer with recharging pond water. The major coastal receptors receiving mass from the wastewater plume, represented by groups of MODFLOW model cells, are shown in figure 12. An accounting of the number and traveltime of particles reaching receptors was used to estimate the time history of nitrogen mass loading to these receptors. Particles were assigned a mass by multiplying the nitrogen concentration by the volume of water in the cell of origin. The spatial distribution of discharge within a given receptor was not determined; the model produced a curve of cumulative nitrate- $\mathrm{N}$ or ammonium-N mass in relation to time for the entire area of the receptor, irrespective of where the individual particles discharged to the river or embayment. Curves of cumulative total nitrogen mass in relation to time were calculated for the receptors by summing the curves of cumulative nitrate-N and ammonium-N. Nitrate-N, ammonium-N and total-N loads in kilograms per year were computed from smoothed (LOWESS, locally weighted scatterplot smoothing) curves of cumulative-mass. Limitations of the mass-loaded particle-tracking approach are discussed in detail in the Limitations of Modeling Analysis section. 


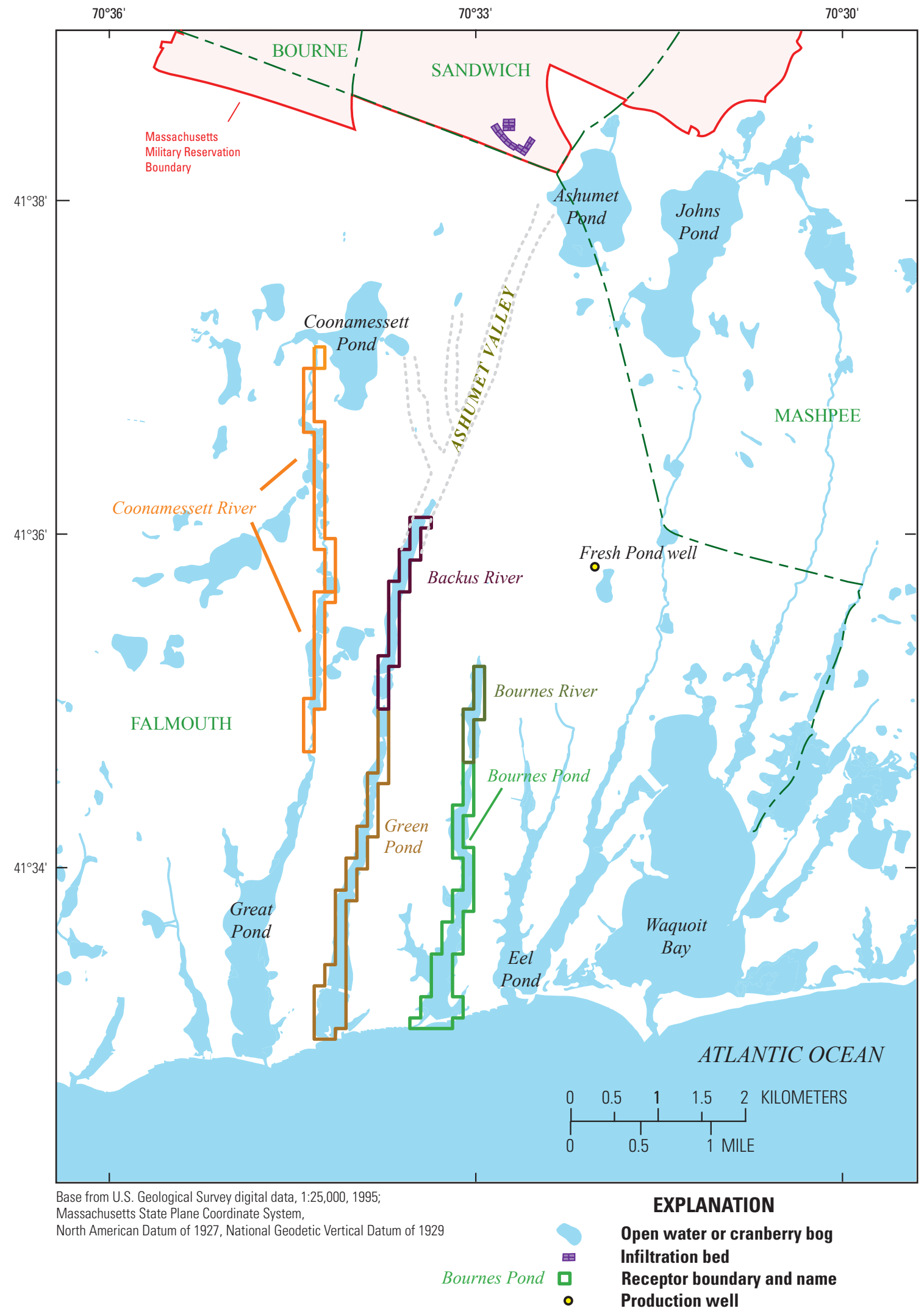

Figure 12. Rivers and embayments (major receptors) that receive most of the simulated discharge of nitrogen in the treatedwastewater plume, Ashumet Valley, Cape Cod, Massachusetts. Major receptors are shown as groups of cells in the MODFLOW model grid. 


\section{Nitrogen Loads to Receptors}

Particle-tracking simulations indicate that nearly all of the nitrogen in the 2007 wastewater plume will be transported to the coastal discharge areas near the leading edge of the plume: the Coonamessett River, Backus River, Green Pond, and Bournes River (fig. 12). The remainder will discharge mainly to Bournes Pond and Ashumet Pond, with minor quantities transported by deep flowpaths to Waquoit Bay and the Atlantic Ocean. The Coonamessett River, Backus River, and Bournes River are freshwater streams that derive most of their flow from groundwater and discharge to the headwaters of Great Pond, Green Pond, and Bournes Pond, respectively (fig. 12). Great Pond, Green Pond, Bournes Pond, Eel Pond, and Waquoit Bay (fig. 1) are brackish to saltwater coastal embayments that are separated from the Atlantic Ocean by barrier beaches except at connecting channels. These embayments receive direct groundwater discharge as well as surfacewater inflows from headwater streams. With the exception of Green and Bournes Ponds, the simulated mass of nitrogen discharging directly to the embayments was negligible. Cumulative mass and loads were computed for nitrate-N, ammonium- $\mathrm{N}$, and total $\mathrm{N}$ (sum of nitrate- $\mathrm{N}$ and ammonium-N). The loads reported here assume that transport of nitrogen to the groundwater/surface-water interface results in discharge to surface water; biogeochemical processes near the interface (in the aquifer or subterranean estuary) that may reduce or eliminate nitrate and ammonium loads before discharge are not considered.

\section{Nitrate Loads}

Because particle tracking was used to simulate transport, nonreactive transport was assumed, and the total mass of nitrate- $\mathrm{N}$ in the treated-wastewater plume $(87,000 \mathrm{~kg})$ in 2007 eventually reaches discharge areas. A lack of nitrate mass loss along flow paths is consistent with the conceptual model for nitrate reactivity that was developed from the 1994 and 2007 plume snapshot data. By 2007, 12 years after cessation, concentrations in virtually the entire plume were near residual levels and ongoing denitrification that would reduce concentrations further did not appear to be occurring on a large spatial scale. However, a low rate of denitrification along groundwater flow paths or biotransformation at the groundwater/surface-water interface could reduce nitrate concentrations in the 2007 plume. Consequently, the mass-loaded particletracking provides an upper-end estimate (worst case scenario) of nitrate loads to the coastal discharge areas.

Groundwater flow generally transports the nitrate plume southward toward the Atlantic Ocean. The plan-view distribution of simulated 3D particle tracks originating from the cells with nonzero concentrations in the gridded nitrate plume is shown in figure 13. For reference, the plume outline at $-16.8 \mathrm{~m}$, an altitude at which the plume is areally extensive, also is shown. Some of the differences between the particle tracks and the plume outline are caused by juxtaposing the 3D particle tracks for the entire plume against a two-dimensional (2D) slice of the plume. However, as discussed in greater detail in the Limitations of Modeling Analysis section, most of the differences are related to the simulation of the surfacewater features in the model.

Simulations indicate that approximately 95 percent of the 2007 nitrate plume discharges to the Coonamessett River, Backus River, Green Pond, and Bournes River (hereafter referred to as the major receptors of nitrate). Bournes Pond and Ashumet Pond receive most of the remaining mass, with much smaller amounts discharging to Waquoit Bay and the Atlantic Ocean. Traveltimes for individual particles range from less than a year to more than 1,000 years, depending on the proximity of the receptor to the plume and the flow paths taken to reach the receptor. Median simulated traveltimes for transport from the wastewater plume to receptors ranges from 16 years for the Backus River to 69 years for Green Pond (table 3), which is farther from the plume and receives more mass from deeper flowpaths than the other receptors. Simulations indicate that the Fresh Pond well is in an area that receives discharged Ashumet Pond water, and, therefore, is likely not a receptor for wastewater nitrogen from the plume.

Simulations indicate that most of the nitrate in the 2007 plume will discharge to the major receptors within 200 years of 2007 (fig. 14). The Coonamessett River receives the most nitrate-N mass (about 42 percent of the total nitrate-N mass), followed by the Bournes River, Green Pond, and the Backus River (fig. 14A). Simulated discharge to the Coonamessett and Backus Rivers, which are relatively close to the treated-wastewater plume, will occur mainly within 100 years from 2007. In contrast, discharge to the Bournes River and Green Pond will be more gradual. Future discharge to Ashumet Pond is minor because most of the nitrate-N mass in the treated-wastewater plume is already downgradient from the pond. Overall, approximately 76 percent of the total nitrate$\mathrm{N}$ mass in the plume will discharge to the major receptors within 100 years from 2007, 90 percent within 200 years, and 94 percent within 500 years. The Coonamessett River will receive 47 percent $(31,100 \mathrm{~kg})$ of the total nitrate- $\mathrm{N}$ discharged to the major receptors within 100 years from 2007.

The timing and magnitude of simulated nitrate- $\mathrm{N}$ loads will vary among the major receptors (fig. 14B). Simulations indicate that loads will peak within about 50 years of 2007 at all locations. The simulated load to the Backus River will peak at about $350 \mathrm{~kg} / \mathrm{yr}$ nitrate-N relatively quickly ( 25 years from 2007) and then decline rapidly; the last particle will reach the Backus River approximately 150 years from 2007. The load to the Coonamessett River will peak at about $450 \mathrm{~kg} /$ yr nitrate- $\mathrm{N}$ and then decline rapidly over the following 50 years. In contrast, loads to Green Pond and the Bournes River will peak below $200 \mathrm{~kg} / \mathrm{yr}$ nitrate- $\mathrm{N}$ and decline relatively slowly thereafter. With the exception of the Backus River, all of the major receptors receive water from deep flowpaths and, 


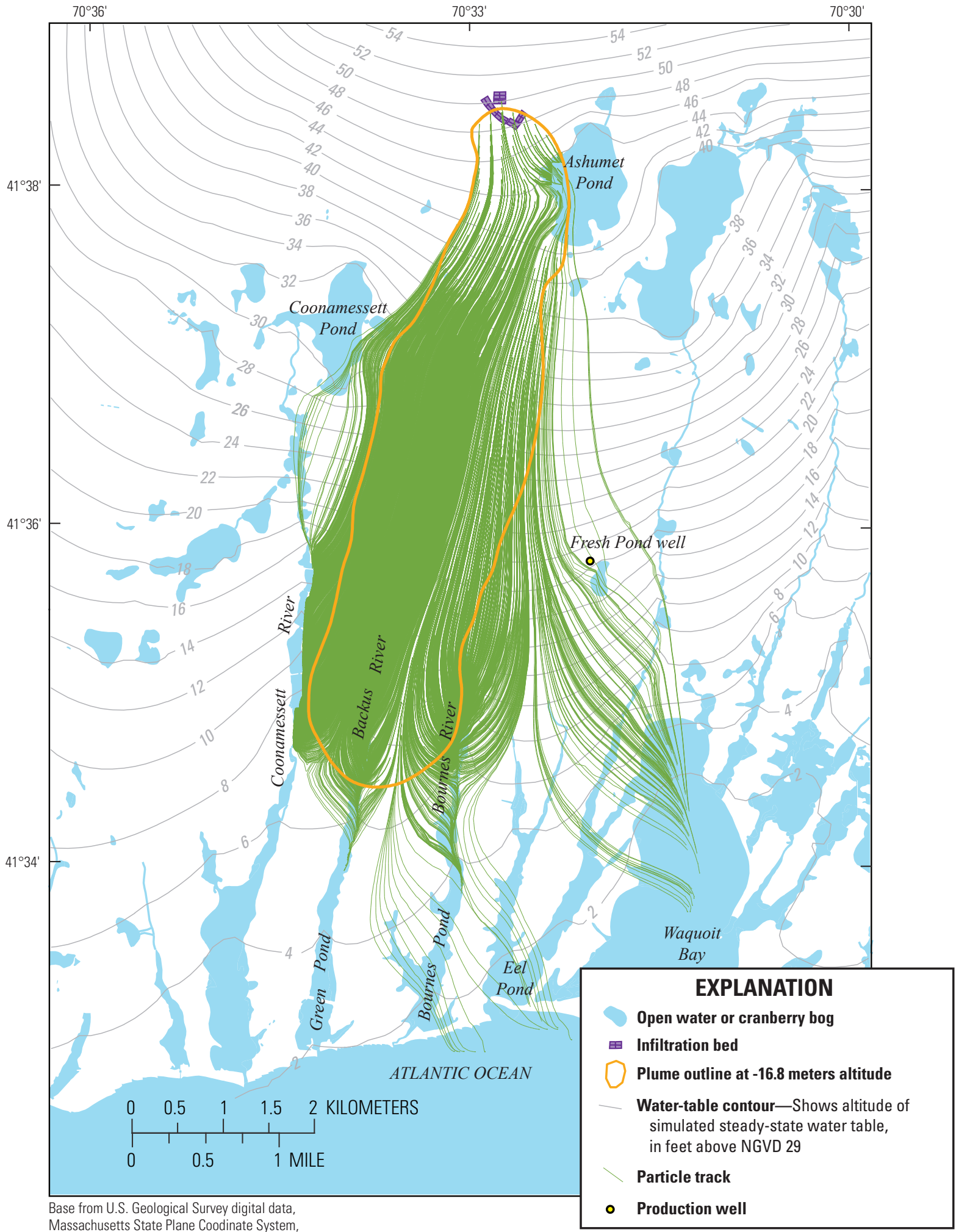

Massachusetts State Plane Coodinate System,

North American Datum of 1927 .

National Geodetic Vertical Datum of 1929

Figure 13. Three-dimensional steady-state particle tracks originating from the 2007 nitrate plume, Ashumet Valley, Cape Cod, Massachusetts. 
Table 3. Median simulated steady-state traveltimes to major receptors for particles originating from the 2007 nitrate and ammonium plumes, Ashumet Valley, Cape Cod, Massachusetts

[Location of receptors shown on figure 12. yr, years]

\begin{tabular}{lccccc}
\hline & \multicolumn{2}{c}{ Nitrate plume } & & \multicolumn{2}{c}{ Ammonium plume } \\
\cline { 2 - 3 } \cline { 5 - 6 } Receptor & $\begin{array}{c}\text { Median } \\
\text { particle } \\
\text { traveltime } \\
\text { (yr) }\end{array}$ & $\begin{array}{c}\text { Number } \\
\text { of } \\
\text { particles }\end{array}$ & & $\begin{array}{c}\text { Median } \\
\text { particle } \\
\text { traveltime } \\
\text { (yr) }\end{array}$ & $\begin{array}{c}\text { Number of } \\
\text { particles }\end{array}$ \\
\hline Backus River & 16 & 614 & & 119 & 80 \\
Bournes River & 67 & 1,619 & & 321 & 122 \\
Coonamessett & 41 & 2,520 & & 171 & 302 \\
$\quad$ River & & & & & \\
Green Pond & 69 & 1,010 & & 452 & 176 \\
\hline
\end{tabular}

consequently, will continue to receive low simulated nitrate$\mathrm{N}$ loads $(1-10 \mathrm{~kg} / \mathrm{yr})$ from the treated-wastewater plume for hundreds of years (data not shown).

\section{Ammonium Loads}

As was the case for the nitrate simulation, nonreactive transport was assumed and the total mass of ammonium-N in the treated-wastewater plume in 2007 (31,600 kg; table 1) eventually reaches discharges areas. Because total ammonium$\mathrm{N}$ mass consists of dissolved-phase and adsorbed-phase pools and an advective particle-tracking simulation cannot transport the adsorbed mass, an equivalent dissolved-phase concentration representing the total mass of ammonium- $\mathrm{N}$ was calculated from $C_{T}=C_{\text {dissolved }}+\left(C_{\text {dissolved }} \times 1.6708\right)$, where $C_{T}$ is the equivalent dissolved-phase concentration, $C_{\text {dissolved }}$ is the dissolved-phase concentration, and 1.6708 is the ratio of adsorbed-phase mass to dissolved-phase mass per unit volume of the aquifer. The simulation assumes that no oxidation reactions occur and the entire plume migrates to coastal receptors as ammonium. Although such a simulation is not consistent with observed ammonium-N mass loss, it is not possible to simulate reactive-ammonium transport realistically with a mass-loaded particle-tracking analysis. Reactions could affect the timing and total mass of biologically reactive nitrogen reaching discharge areas. The present simulation can be viewed as an end-member transport simulation, reflecting maximum traveltimes to receptors and conservation of total ammonium mass in the 2007 plume.

To simulate ammonium transport, particle traveltimes were multiplied by the ammonium retardation factor (R) of 2.5 , resulting in particle migration that is slower than the rate of groundwater flow ( $\mathrm{v}$; that is, at a velocity of $\mathrm{v} / \mathrm{R}$ ) and, therefore, longer traveltimes to reach receptors. The retardation factor was calculated by use of the distribution coefficient $(0.34 \mathrm{~mL} / \mathrm{g})$ determined from sediment batch experiments and is consistent with retardation factors determined from tracer experiments (Ceazan and others, 1989) and the position of the ammonium front in the aquifer (fig. 6).

The plan-view distribution of simulated 3D particle tracks originating from the cells with nonzero concentrations in the gridded ammonium plume is shown in figure 15. For reference, the plume outline at $-7.6 \mathrm{~m}$, an altitude at which the plume is areally extensive, also is shown. Similar to nitrate, some of the differences between the particle tracks and the plume outline are caused by juxtaposing the 3D particle tracks for the entire plume against a 2D slice of the plume. However, as discussed in greater detail in the Limitations of Modeling Analysis section, most of the differences are related to the simulation of the surface-water features in the model.

Simulations indicate that approximately 99 percent of the 2007 ammonium plume will discharge to the Coonamessett River, Backus River, Green Pond, and the Bournes River (hereafter referred to as the major receptors of ammonium). Ashumet Pond will receive negligible ammonium from the 2007 plume. Traveltimes for individual particles range from about 40 to more than 1,000 years, depending on the proximity of the receptor to the plume and the flow paths taken to reach the receptor. Because of sorption and the position of the leading edge of the ammonium plume, median traveltimes to the major receptors are longer for ammonium than for nitrate, ranging from less than 120 years for the Backus River to 450 years for Green Pond.

Simulations indicate that most of the ammonium plume will discharge to receptors within 400 years of 2007 (fig. 16A). Similar to nitrate, the Coonamessett River will receive the most ammonium- $\mathrm{N}$ mass (about 45 percent of the total ammonium-N mass), followed by Green Pond, the Backus River, and the Bournes River. Overall, approximately 5 percent of the total ammonium-N mass in the plume will discharge to receptors within 100 years, 46 percent within 200 years, and 81 percent within 500 years. The discharge to Green Pond accounts for most of the discharge after about 350 years.

The timing and magnitude of simulated ammonium loads varies among receptors (fig. 16B). The distribution of ammonium loads among receptors is similar to that of nitrate. Ammonium loads to the Backus River will peak at about $50 \mathrm{~kg}$ ammonium-N/yr relatively quickly (125 years from 2007) and then decline over the following 200 years. Loads to the Coonamessett River will peak at nearly $200 \mathrm{~kg}$ ammonium-N/yr approximately 200 years from 2007 and then decline rapidly over the following 100 years. Loads to Green Pond and the Bournes River will peak at about $20 \mathrm{~kg}$ ammonium-N/yr and remain elevated for several hundred years (fig. 16B).

\section{Total Nitrogen Loads}

Because total-N loads to most of the major receptors (Coonamessett River, Backus River, Green Pond, and Bournes River) are dominated by discharge of nitrate- $\mathrm{N}$ mass, the total$\mathrm{N}$ load curves (fig. 17) are similar in shape and magnitude to nitrate-N load curves (fig. 14). An exception is the total-N load 
A.

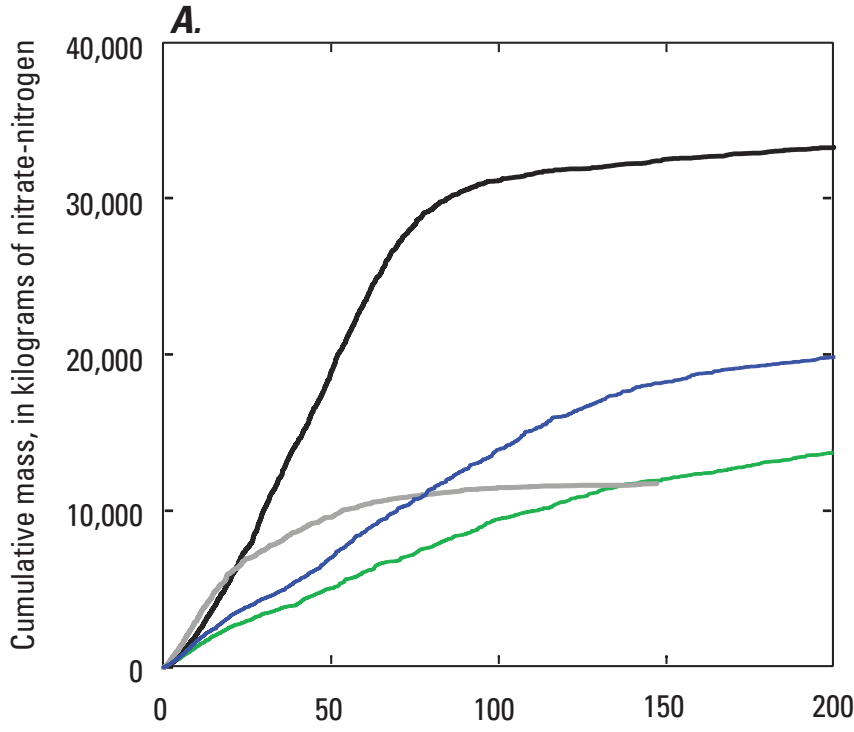

B.

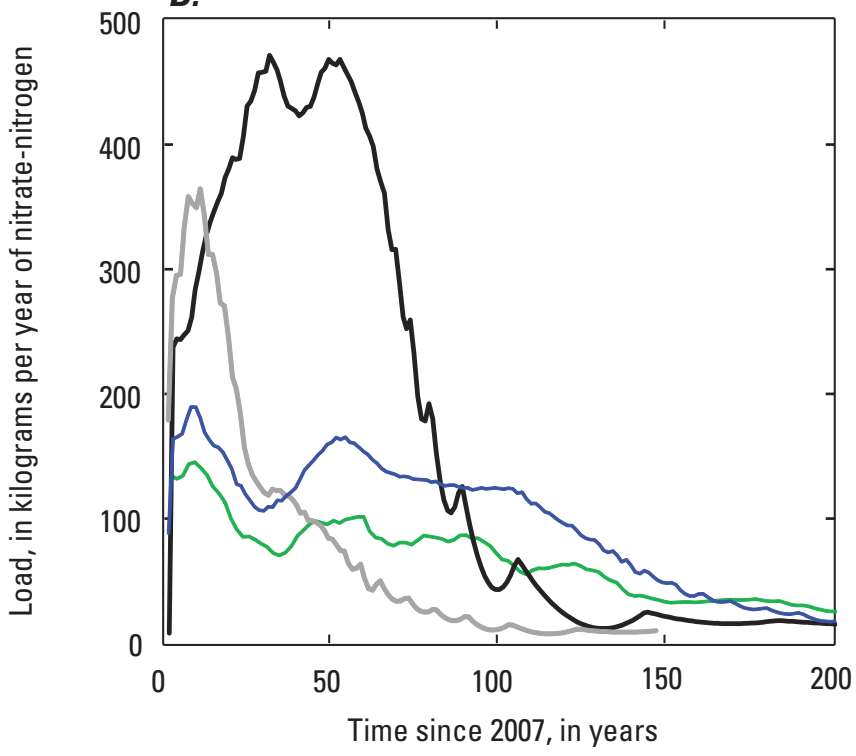

EXPLANATION

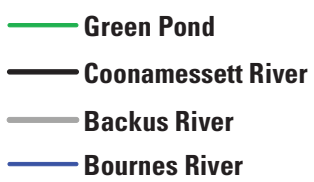

Figure 14. Simulated discharge of nitrate in the 2007 treatedwastewater plume to major receptors, Ashumet Valley, Cape Cod, Massachusetts. A, Cumulative nitrate-nitrogen mass, and $B$, nitrate-nitrogen loads. curve to the Coonamessett River, which is affected by substantial ammonium-N mass. At this location a secondary peak will arrive around 175 years from 2007.

The simulated load curves shown in figures 16 and 17 include the transport of nonreactive ammonium as a reversibly adsorbing species. If nitrification were a dominant reaction and ammonium was being converted rapidly to nitrate relative to residence times in the aquifer, then traveltimes from the ammonium plume to receptors would decrease, peak loads would be higher, and loads would be spread over shorter time intervals compared to migration retarded by adsorption. Because geochemical conditions in the plume are considered to be unfavorable for denitrification, nitrogen mass in the ammonium plume likely would be conserved, and the most significant change would be in the timing and rate of total $\mathrm{N}$ discharge.

Simulations indicate that the Coonamessett River will receive the most cumulative nitrogen mass and the highest rates of discharge (loads) from the 2007 treated-wastewater plume. The Backus and Bournes Rivers and Green Pond also will receive substantial direct discharge of nitrogen, mostly as nitrate, from the plume. Surface-water inflows from the Backus, Bournes, and Coonamessett Rivers (which contain nitrogen from groundwater discharge) to Green Pond, Bournes Pond, and Great Pond, respectively, contribute to the total load of nitrogen to these embayments.

\section{Comparison of Nitrogen Loads From the Treated- Wastewater Plume to Nitrogen Loads From Nonpoint Sources}

The coastal rivers and embayments in Falmouth receive nitrogen from sources other than the treated-wastewater plume, such as atmospheric deposition, fertilizer, and wastewater from septic systems. Septic systems and fertilizer applied to residential, commercial, agricultural, and recreational areas are the major sources of anthropogenic nitrogen in the coastal watersheds of Falmouth (Bowen and Valiela, 2001; Howes and others, 2005). At the watershed scale, these numerous and widely distributed small point sources are typically referred to as nonpoint nitrogen sources. In contrast, larger, discrete sources such as the wastewater plume produced by the MMR wastewater treatment plant and landfills are considered separately as point sources. Nonpoint-source nitrogen is released to the ground surface as fertilizer or to the soil zone as wastewater effluent and conveyed to discharge areas by groundwater and surface-water flow. Nitrate is often the dominant form of nitrogen reaching the water table from wastewater releases (for example, DeSimone and Howes, 1998), but under certain circumstances, such as when flow paths are short, a substantial portion of anthropogenic nitrogen reaching discharge areas may be in the form of dissolved organic nitrogen (Kroeger and others, 2006a).

In 2005, there was substantial residential development near the treated-wastewater plume (fig. 18). The 11 land-use 


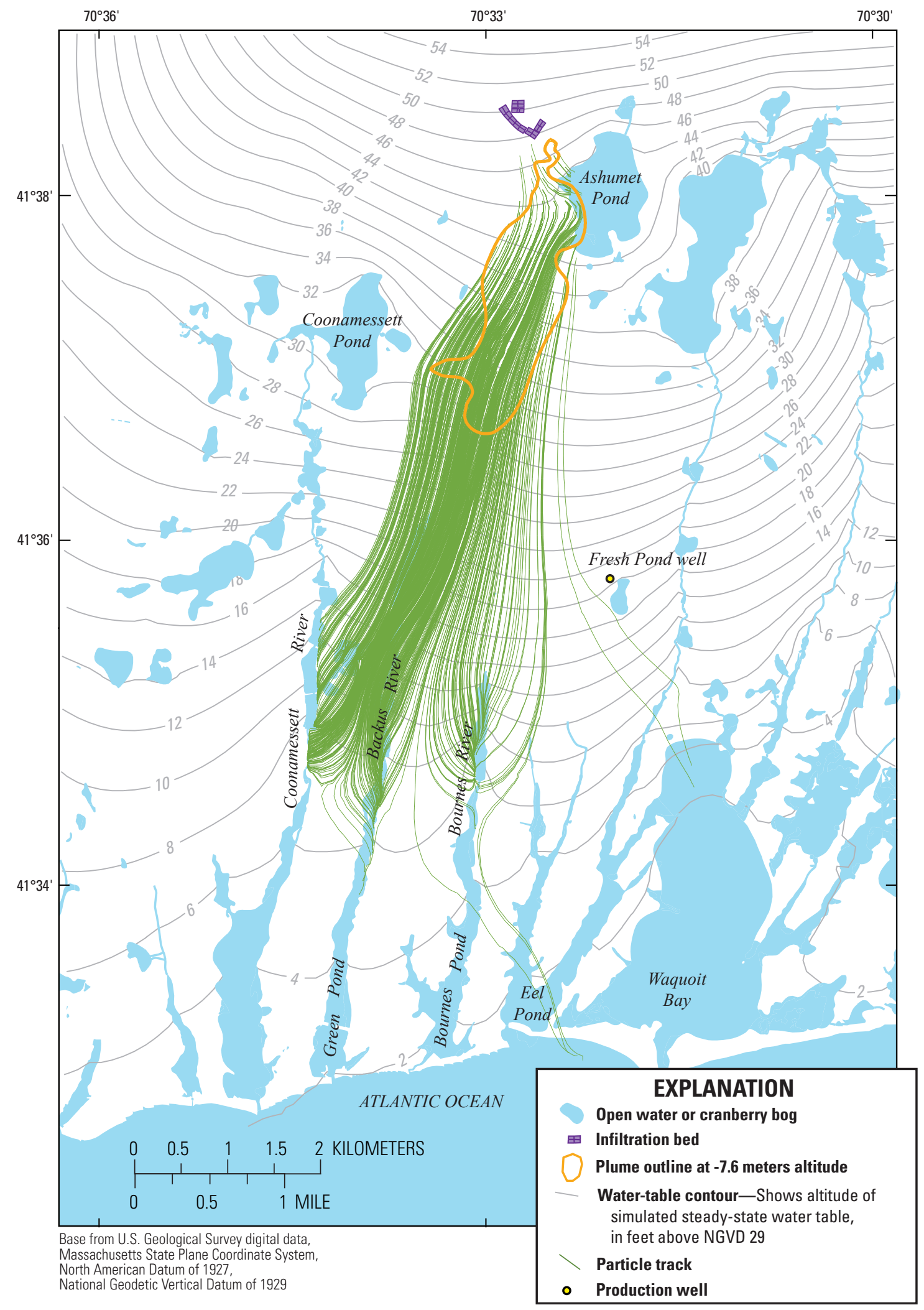

Figure 15. Three-dimensional steady-state particle tracks originating from the 2007 ammonium plume, Ashumet Valley, Cape Cod, Massachusetts. 

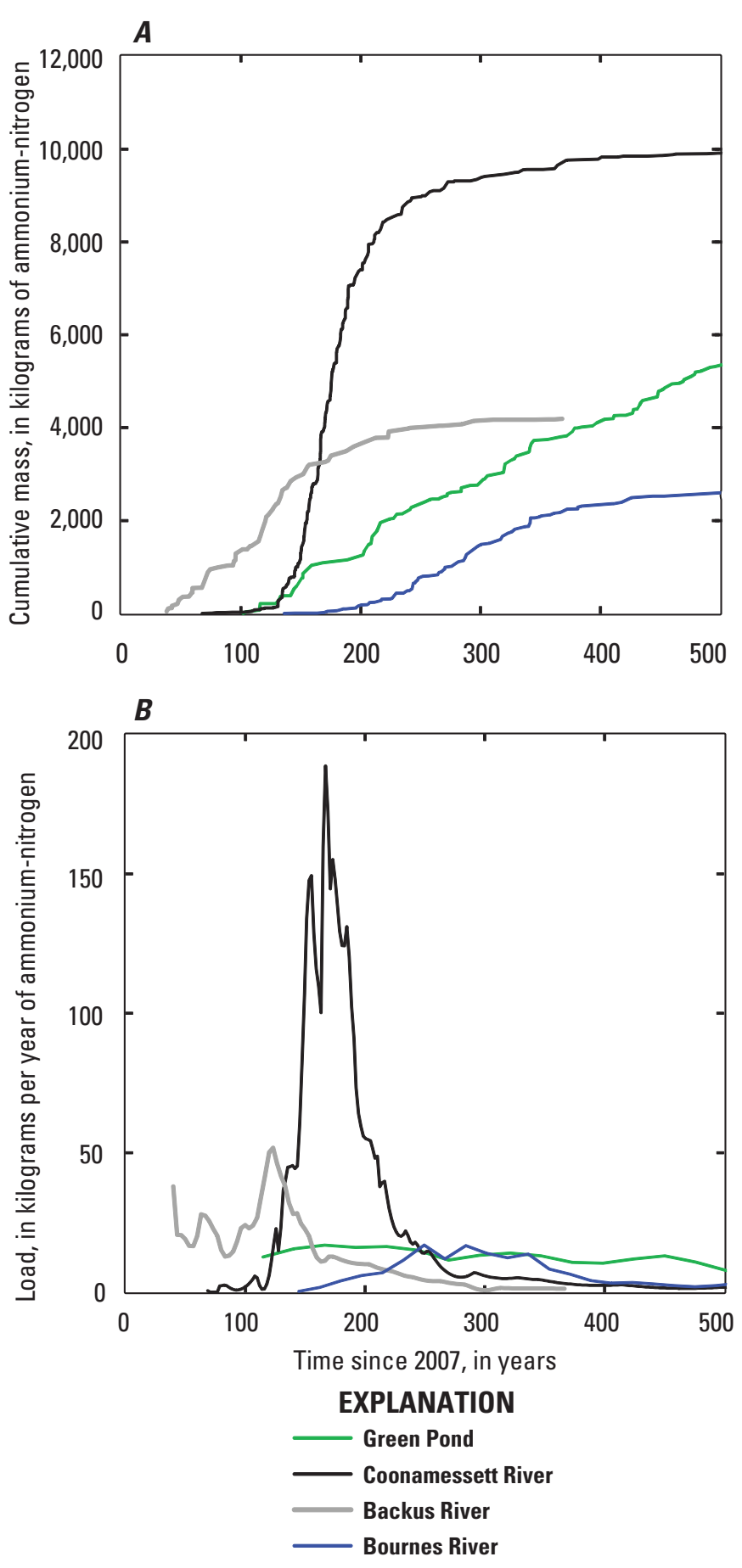

Figure 16. Simulated discharge of ammonium in the 2007 treated-wastewater plume to major receptors, Ashumet Valley, Cape Cod, Massachusetts. $A$, Cumulative ammonium-N mass, and $B$, ammonium-nitrogen loads. categories shown in figure 18 were aggregated from 33 land-use codes in the 2005 Massachusetts land-use data layer (Massachusetts Office of Geographic Information, 2010). The aggregated developed land-use categories include high-density residential (single-family houses on less than $1 / 4$-acre lots and multifamily dwellings), medium-density residential (houses on $1 / 4$ - to $1 / 2$-acre lots), low-density residential (houses on $1 / 2$ - to 1 -acre lots), very-low-density residential (rural properties with houses on greater than 1-acre lots), commercial-industrialtransportation (shopping centers, stores, medical offices, schools, churches, colleges, hospitals, municipal properties, industrial facilities, and major roads), agricultural (cropland, pasture, orchards, nurseries, and cranberry bogs), and open urban (cemeteries and participation recreational areas such as golf courses and athletic fields). Residential development is particularly dense near the coast. Because these areas are unsewered, wastewater is disposed to the ground through onsite septic systems.

To evaluate the contribution of the nitrogen loads from the treated-wastewater plume to the total nitrogen loads to the discharge areas, the simulated wastewater-plume loads were compared to nonpoint-source (watershed) loads calculated by the Massachusetts Estuaries Project (MEP) (Howes and others, 2005). As part of a study to determine nitrogen load thresholds for use in evaluating nitrogen management alternatives in the watersheds, the MEP calculated nonpoint-source nitrogen loads for the watersheds to the embayments in the town of Falmouth by using a linked watershed-embayment model. The linked model uses a nitrogen loading submodel to calculate nonpoint-source loads based on predetermined nitrogen loading rates for specific land-use types. The MEP study determined that most of the load (66 to 86 percent) occurred in parts of the watershed with relatively little recent land-use change and groundwater traveltimes of less than 10 years. Consequently, it was assumed that nitrogen entering a watershed was approximately in balance with nitrogen discharging to embayments and temporally varying loads were not calculated.

Results of the MEP study (Howes and others, 2005; table IV-4) indicate that the 2005 nonpoint-source nitrogen loads were $16,866 \mathrm{~kg} / \mathrm{yr}$ (46 kg/d) to the Coonamessett River; $3,210 \mathrm{~kg} / \mathrm{yr}$ (9 kg/d) to the Backus River; $7,356 \mathrm{~kg} / \mathrm{yr}(20 \mathrm{~kg} / \mathrm{d})$ to Green Pond; and $2,583 \mathrm{~kg} / \mathrm{yr}(7 \mathrm{~kg} / \mathrm{d})$ to the Bournes River (table 4). Total watershed loads are composed of contributions from natural background sources, lawn fertilizers, direct runoff from impervious surfaces, and wastewater from septic systems. Of these nonpoint sources, wastewater from septic systems was determined to be the largest contributor, accounting for up to 75 percent of the total nonpoint-source load. The MEP nonpoint-source loads discussed herein exclude the nitrogen load from the MMR treated-wastewater plume, which is estimated to be about $1,030 \mathrm{~kg} / \mathrm{yr}$ (Howes and others, 2005). The MEP wastewaterplume nitrogen load $(1,030 \mathrm{~kg} / \mathrm{yr})$ is in agreement with the results of this study; simulations indicate that the sum of the 


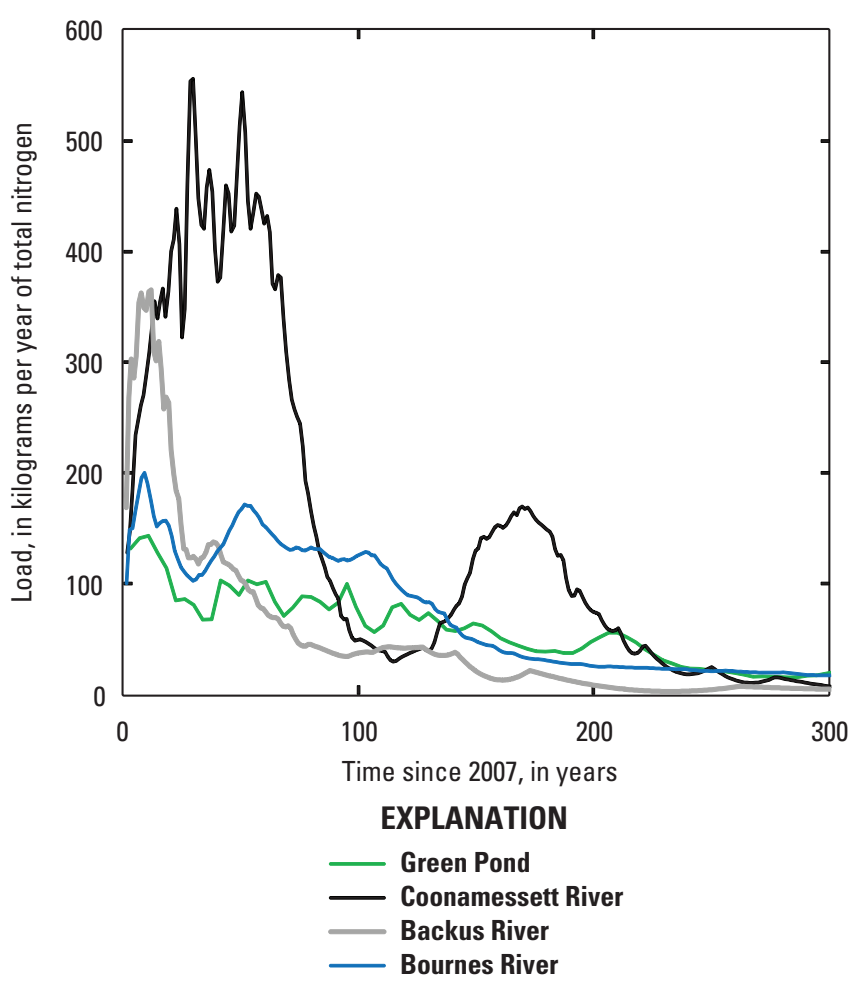

Figure 17. Simulated discharge of total nitrogen in the 2007 treated-wastewater plume to major receptors, Ashumet Valley, Cape Cod, Massachusetts.

peak total-N loads to the major receptors will be about 1,250 $\mathrm{kg} / \mathrm{yr}$ over the next 100 years (fig. 17).

MEP steady-state nonpoint-source loads generally are much higher than total $\mathrm{N}$ wastewater-plume loads for the receptors receiving nitrogen from the plume. For the Coonamessett River, the simulated peak total-N wastewater-plume load of $550 \mathrm{~kg} / \mathrm{yr}$ that occurs about 35 years from 2007 (fig. 17) is 3.3 percent of the $16,866 \mathrm{~kg} / \mathrm{yr}$ nonpoint-source load (table 4). Simulated wastewater-plume nitrogen loads before and after the peak are less than about 1 percent of the nonpoint-source loads. For the Backus River, the peak load of $350 \mathrm{~kg} / \mathrm{yr}$ that occurs about 25 years from 2007 is 10.9 percent of the $3,210 \mathrm{~kg} / \mathrm{yr}$ nonpoint-source load. Simulated treatedwastewater plume nitrogen loads after the peak are less than about 2 percent of the nonpoint-source load. For Green Pond, the peak load of $150 \mathrm{~kg} / \mathrm{yr}$ that occurs about 25 years from 2007 is 2.0 percent of the $7,356 \mathrm{~kg} / \mathrm{yr}$ nonpoint-source load. For the Bournes River, the peak load of $200 \mathrm{~kg} / \mathrm{yr}$ that occurs about 25 years from 2007 is 7.7 percent of the $2,583 \mathrm{~kg} / \mathrm{yr}$ nonpoint-source load. The simulated treated-wastewater plume load for the Bournes and Green River decreases gradually over 200 years to approximately $50 \mathrm{~kg} / \mathrm{yr}$, which is less than 2 percent of the nonpoint-source load to the respective receptors. Overall, the simulated total-nitrogen loads from the treated-wastewater plume are much lower than the corresponding steady-state nonpoint-source loads from the watershed; peak plume loads are equal to 11 percent or less of the nonpoint-source loads.

\section{Limitations of Modeling Analysis}

The modeling analysis in this study was done with a deterministic groundwater-flow model in which hydraulic conductivities, recharge, and boundary leakances were determined by trial-and-error calibration to observations of hydraulic head and streamflow. The model is assumed to represent the flow system adequately because the spatial distribution of hydraulic conductivity is based on an understanding of the depositional history of the glacial sediments in the region; values of hydraulic conductivity, boundary leakance, and recharge are reasonable and consistent with previous investigations; and simulation results reasonably match observations of heads and streamflows. However, the model produces a simulated flow field that is nonunique because different model configurations can produce similar head distributions. Flowlines in the aquifer also are strongly affected by hydraulic boundaries such as ponds, streams, and coastal waters, but because boundary geometries are static, simulated particle tracks likely would be similar for a range of model configurations. Despite these issues, if the model represents the flow system adequately and is calibrated to observed conditions, then simulated particle tracks are reasonably representative of advective flowpaths in the aquifer at a regional scale.

Simulated traveltimes also can be affected by model construction and parameterization. If hydraulic conductivity and recharge rates are changed in a correlated manner, then a similar calibrated hydraulic head distribution is produced, but groundwater fluxes and traveltimes change. For example, higher hydraulic conductivity and recharge rates that produce a reasonable calibrated head distribution would lead to higher groundwater fluxes and decreased traveltimes compared to the calibrated model used in the study. Although the values of these parameters are constrained to an extent by independent observations, they are often adjusted during model calibration to achieve the best model fit to observed heads and streamflows, and the final combination of values directly affects traveltimes in the aquifer. Another factor affecting traveltimes is aquifer porosity. A uniform value of 0.35 was used for these simulations, but the porosity of glacial sand and gravel can range from 0.25 and 0.40 . Groundwater velocity is inversely proportional to porosity; decreasing porosity increases velocity and decreases traveltime.

The analysis also assumes steady-state flow conditions based on a constant recharge rate. Although recharge varies monthly and yearly, hydraulic gradients in the aquifer generally do not vary over time because of the small time scale of recharge variability compared to the much larger time scale of 


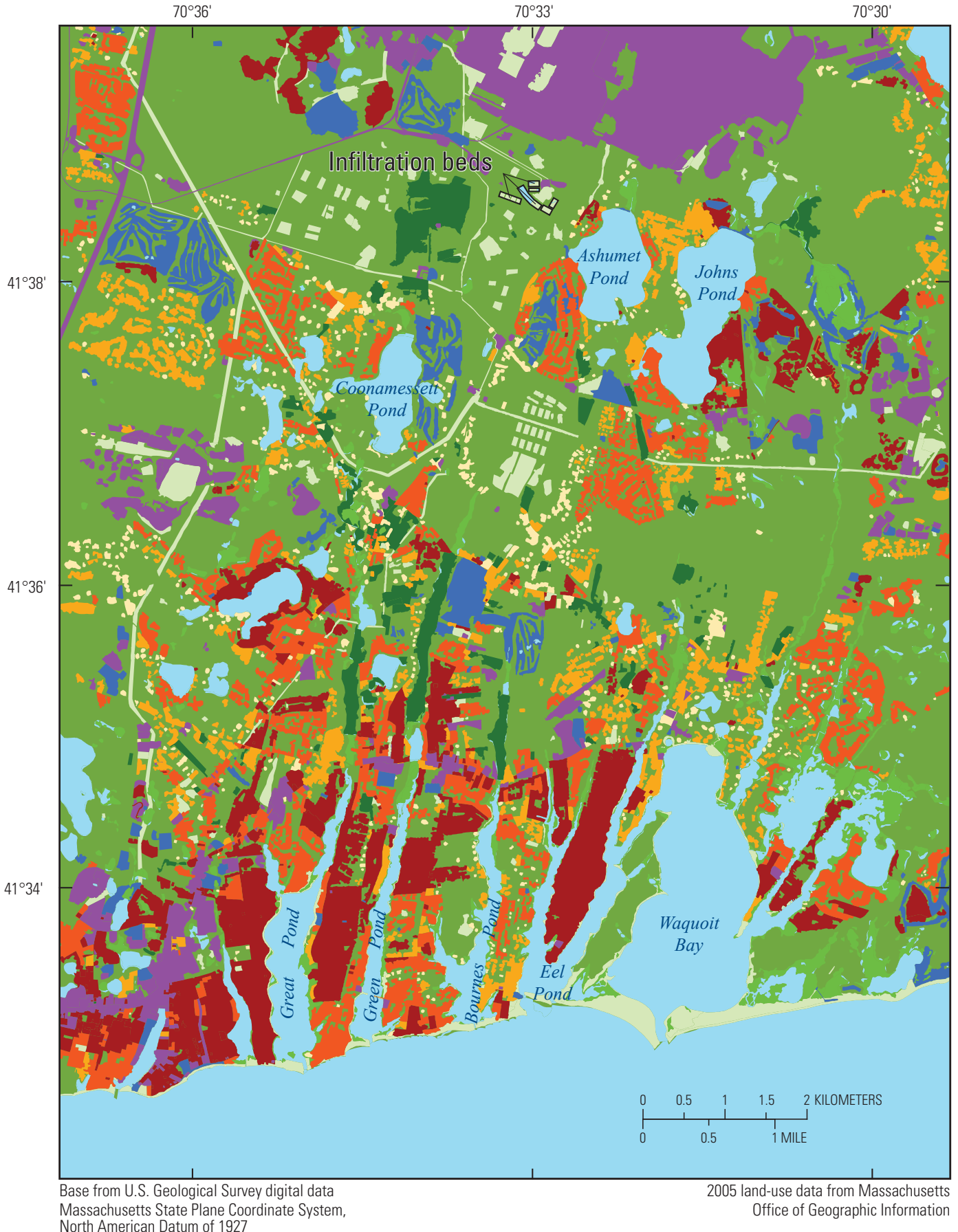
North American Datum of 1927

\section{Land use}

Commercial-industrial-transportation
High-density residential
Medium-density residential
Low-density residential
Very-low-density residential

\section{EXPLANATION}

\begin{tabular}{|l|}
\hline Agriculture \\
\hline Open undeveloped \\
\hline Forest \\
\hline Forested and nonforested wetland \\
\hline Open urban \\
Water
\end{tabular}

Figure 18. Generalized land use near the treated-wastewater plume, Ashumet Valley, Cape Cod, Massachusetts. 
Table 4. Steady-state nonpoint-source and peak treated-wastewater plume nitrogen loads to major receptors, Ashumet Valley, Cape Cod, Massachusetts

[kg/yr, kilograms per year; Steady-state nonpoint-source nitrogen loads from Howes and others (2005). Location of receptors shown on figure 12]

\begin{tabular}{lccc}
\hline Receptor & $\begin{array}{c}\text { Steady-state nonpoint-source } \\
\text { nitrogen load } \\
(\mathbf{k g} / \mathbf{y r})\end{array}$ & $\begin{array}{c}\text { Peak nitrogen treated-wastewater } \\
\text { plume load } \\
(\mathbf{k g} / \mathbf{y r})\end{array}$ & $\begin{array}{c}\text { Ratio of peak wastewater plume } \\
\text { load to nonpoint-source load } \\
\text { (percent) }\end{array}$ \\
\hline Backus River & 3,210 & 350 & 10.9 \\
Bournes River & 2,583 & 200 & 7.7 \\
Coonamessett River & 16,866 & 550 & 3.3 \\
Green Pond & 7,356 & 150 & 2.0 \\
\hline
\end{tabular}

advective transport. Walter and Masterson (2003) compared particle tracks on northwestern Cape Cod by using steadystate and transient flow simulations and found that the particle tracks were nearly identical in most parts of the aquifer (transient conditions were more influential near water-table divides and hydrologic boundaries). This result indicates that it is reasonable to use a steady-state model to simulate transport of the treated-wastewater plume even though recharge is variable. Variable groundwater withdrawals for irrigation and water supply also may affect hydraulic gradients. In particular, operation of wells for cranberry agriculture (bog irrigation and flooding) may affect local gradients near certain discharge areas of the treated-wastewater plume; these wells are not represented in the model. Long-term changes in recharge rates or sea level that may occur in response to possible future changes to the climate in the Northeast also are not represented in the analysis; therefore, load curves represent a projection of current conditions into the future.

Another limitation is that the regional model lacks detailed hydraulic data for the surface-water features (streams, ponds, and coastal embayments) that compose the discharge areas for the treated-wastewater plume. For streams these data include streamflow, streambed altitude, and hydraulic characteristics of streambed sediments. As shown in figures 13 and 15 , the large deviations of particle pathlines from the plumes appear largely to be related to the simulated surface-water features in the model. For example, the few particle pathlines that reach Waquoit Bay result from particles flowing under Ashumet Pond; a higher conductance for the pond bottom sediment might have resulted in more capture of deeper flowpaths in this area. Similarly, the particle pathlines that deviate from the western edge of the plume are affected by the Coonamessett River. This effect may indicate that flows in this river are overrepresented in the model. Even if the match between simulated and observed streamflow at the mouth of the Coonamesett River is reasonable, the model could be simulating too much discharge in the northern portion of the river, and, therefore, drawing particle pathlines too far in a westerly direction across the mapped plume boundary. Streamflow data for the northern part of the river were limited. The distributions of particles discharging to the streams and the downgradient headwaters of the adjoining embayments also are based on current knowledge of the distribution of flows between these surface-water bodies. Any changes in the simulated distribution of flows would affect the distribution of particles and the timing and magnitude of simulated loads to these receiving waters that are shown in figures 14, 16, and 17 and table 3 . In addition, manipulation of flows in the cranberry bogs adds to the complexity of understanding average flow conditions in these streams.

The regional model also tends to pull particles deeper than the lower plume boundary (data not shown), which increases traveltimes in the aquifer and affects the distribution of the particles that discharge to receptors. Adjustment of model parameters such as hydraulic conductivity to minimize downward flow and keep particles within the gridded plume would improve the agreement between simulated and observed transport. In general, explicit consideration of the wastewaterplume location during calibration likely would lead to better agreement between simulated and observed nitrogen transport and reduce particle-path excursions across mapped plume boundaries. A different modeling approach also could provide better agreement between simulated and observed nitrogen transport in the aquifer. For example, solute-transport models, which typically account for advection, dispersion, adsorption, and biological reactions, could improve the simulation of nitrogen transport in the aquifer and loading to coastal discharge areas.

The regional model (Walter, 2013) originally was designed and used for advective transport of nitrate on western Cape Cod, including in this study area, so it was considered to be appropriate for the simulation of nitrogen transport in the treated-wastewater plume. However, given the modeling (and plume mapping) limitations discussed above, there is considerable uncertainty associated with the results presented in this study. The simulated nitrogen loading curves should be viewed as only one plausible set of outcomes based on particle-tracking simulations with the current regional model for western Cape Cod. Future modeling analyses would benefit from additional streamflow calibration data to better represent flows in the surface-water features near the treated-wastewater plume; inclusion of the location of the plume during calibration of the flow model; and use of a solute-transport model to simulate nitrogen transport in the aquifer. 


\section{Summary}

Land disposal of treated wastewater from a treatment plant in operation from 1936 to 1995 on the Massachusetts Military Reservation (MMR) created a plume of contaminated groundwater that is migrating toward the coastal embayments in the town of Falmouth, Massachusetts. Although the plume has been investigated extensively by the U.S. Geological Survey (USGS) and other researchers since the late 1970s, the 3D distribution and transport of nitrogen at the plume scale (that is, the entire plume) has received relatively little study. The fate of nitrogen $(\mathrm{N})$ in the treated-wastewater plume is of concern because land-use changes in coastal watersheds have led to nitrogen enrichment in the coastal embayments. To develop a better understanding of the potential effect of the treatedwastewater plume on coastal discharge areas, the USGS, in cooperation with the Air Force Center for Engineering and the Environment, evaluated the fate of nitrogen in the plume. The objectives of the study were to calculate the mass of nitrogen in the treated-wastewater plume as of 2007, evaluate the occurrence and extent of reactions that could remove nitrogen mass in the aquifer before discharge, simulate the spatial and temporal discharge of nitrogen to the rivers and coastal embayments in Falmouth, and compare treated-wastewater plume loads to steady-state nonpoint-source loads.

Groundwater samples from two large sampling events in 1994 and 2007 were used to map the size and location of the wastewater plume, calculate the mass of nitrogen species (nitrate and ammonium are the predominant nitrogen species in the plume), evaluate changes in plume mass since cessation of wastewater disposal in 1995, and create a gridded dataset suitable for use in nitrogen-transport simulations. In 2007, the treated-wastewater plume was about 1,200 meters (m) wide, $30 \mathrm{~m}$ thick, and 7,700 $\mathrm{m}$ long and contained approximately 87,000 kilograms $(\mathrm{kg})$ nitrate-N and 31,600 kg total ammonium-N. Consistent with a relatively slow rate of migration caused by adsorption, the ammonium plume was substantially smaller than the nitrate plume, extending roughly 3,300 m downgradient from the infiltration beds in 2007. Between 1994 and 2007, the mass of nitrate- $\mathrm{N}$ in the plume decreased by 7.8 percent, whereas the mass of ammonium-N decreased by 37.7 percent. Spatial patterns of nitrate concentrations and geochemical conditions in the wastewater plume indicate that the post-cessation rate of nitrate removal by denitrification is low or negligible. In contrast to nitrate, the ammonium plume appears to be undergoing biotransformation in the aquifer. The reactions responsible for ammonium mass loss are unclear. However, based on changes in spatial patterns in concentrations of ammonium and dissolved oxygen, nitrification is most likely responsible for the apparent loss. Nitrification converts ammonium to nitrate, which is more mobile and persistent in the aquifer. Consequently, nearly all of the biologically reactive nitrogen in the 2007 plume may be transported to coastal discharge areas as either nitrate or ammonium with relatively little loss to an environmentally nonreactive end product such as nitrogen gas. If a reaction such as anammox (the anaerobic oxidation of ammonium), which consumes both ammonium and nitrate, is widespread in the plume, then nitrogen-transport simulations that assume nonreactive (no mass loss in the aquifer) transport of nitrogen in the 2007 plume provide an upperend estimate of loading to coastal discharge areas. Additional data collection would be useful for evaluating nitrogen mass and reactivity at the plume scale.

Nitrogen transport was simulated with a previously calibrated regional 3D MODFLOW groundwater-flow model. Mass-loaded particle tracking was used to simulate the advective transport of nitrogen in the 2007 treated-wastewater plume to groundwater discharge areas (or receptors) along the coast. The movement and discharge of nitrogen were quantified by assigning particles to the model cells encompassing the wastewater plume and then transporting them to discharge areas under steady-state flow conditions. An accounting of the number and traveltime of particles reaching receptors was used to estimate the time history of nitrogen mass loading to these receptors. Particles were converted to mass by multiplying the nitrogen concentration assigned to the cell of particle origin by the volume of water in the cell. Overall, the use of particle tracking to simulate mass loading to coastal discharge areas is most appropriate for nonsorbing, nonreactive nitrogen species such as nitrate. To simulate ammonium transport, particle traveltimes were multiplied by the ammonium retardation factor of 2.5. The simulation, therefore, assumes that no oxidation reactions occur and that the entire ammonium plume migrates to coastal receptors as ammonium. Although such a simulation is not consistent with the observed ammonium-N mass loss, it is not possible to simulate reactive ammonium transport realistically with a mass-loaded particle-tracking analysis. The present simulation can be viewed as an endmember-transport simulation, reflecting maximum traveltimes to receptors and conservation of the total ammonium mass in the 2007 plume.

Simulation results indicate that about 95 percent of the nitrate- $\mathrm{N}$ and 99 percent of the ammonium-N in the treatedwastewater plume will discharge to the coastal receptors nearest to the downgradient end of the plume: the Coonamessett River, Backus River, Green Pond, and Bournes River. The Coonamessett River will receive the most nitrate-N mass (about 42 percent of the total nitrate-N mass) followed by the Bournes River, Green Pond, and the Backus River. Approximately 76 percent of the total nitrate-N mass in the plume will discharge to these receptors within 100 years of 2007, 90 percent within 200 years, and 94 percent within 500 years. Nitrate loads will peak within about 50 years (of 2007) at all major receptors. The highest peak loads will occur at the Coonamessett River (450 kilograms per year (kg/yr) nitrate-N) and Backus River (350 kg/yr nitrate-N). As was the case for nitrate, the Coonamessett River will receive the most ammonium-N mass (about 45 percent of the total mass) followed by Green Pond, the Backus River, and the Bournes River. Because of adsorption, traveltimes for ammonium are longer than for nitrate; as a result, approximately 5 percent of the total ammonium- $\mathrm{N}$ mass in the plume will discharge 
to receptors within 100 years of 2007,46 percent within 200 years, and 81 percent within 500 years. The discharge to Green Pond accounts for most of the ammonium discharge after about 350 years. Simulations indicate that the Coonamessett River will receive the most cumulative nitrogen mass and the highest rate of discharge (load) from the 2007 treatedwastewater plume. The Backus and Bournes Rivers and Green Pond also will receive substantial discharge of nitrogen (mostly as nitrate) from the plume. Ongoing discharge to Ashumet Pond is minor because most of the nitrogen mass in the plume already is downgradient from the pond. The loads reported in this report assume that transport of nitrogen to the groundwater/surface-water interface results in discharge to surface water; biogeochemical processes near the interface (in the aquifer or subterranean estuary) that may reduce or eliminate loads before discharge are not considered.

To evaluate the contribution of the nitrogen loads from the treated-wastewater plume to total nitrogen loads to the discharge areas, the simulated treated-wastewater plume loads were compared to steady-state nonpoint-source loads calculated by the Massachusetts Estuaries Project for 2005 . Wastewater nitrogen from residential septic systems is the major source of anthropogenic nitrogen in the groundwater watersheds of the coastal embayment systems. Nonpointsource nitrogen loads in 2005 were $16,866 \mathrm{~kg} / \mathrm{yr}$ to the Coonamessett River, 3,210 kg/yr to the Backus River, 7,356 kg/yr to Green Pond, and 2,583 kg/yr to the Bournes River. Simulated peak total-N wastewater-plume loads were $550 \mathrm{~kg} / \mathrm{yr}$ to the Coonamessett River, $350 \mathrm{~kg} / \mathrm{yr}$ to the Backus River, $150 \mathrm{~kg} / \mathrm{yr}$ to Green Pond, and $200 \mathrm{~kg} / \mathrm{yr}$ to the Bournes River. Before and after peak loads, simulated treated-wastewater plume loads are about 1 to 2 percent of nonpoint-source loads. Simulation results indicate that the total-N loads from the treated-wastewater plume are much lower than corresponding steady-state nonpoint-source loads from the watersheds; peak plume loads are equal to 11 percent or less of the nonpointsource loads.

\section{References Cited}

Air Force Center for Engineering and the Environment, 2010, Groundwater plume maps and information booklet: Air Force Center for Engineering and the Environment, Massachusetts Military Reservation, Cape Cod, Mass., April 2010, 31 p.

Aquaveo, 2012, GMS software documentation: Groundwater Modeling System version 7.0, accessed September 2012, at http://www.aquaveo.com/.
Barber, L.B., II, 1992, A hierarchical analytical approach to evaluating the occurrence, distribution, and biogeochemical fate of organic contaminants in sewage-contaminated groundwater, in Lesage, S., and Jackson, R.E., eds., Groundwater quality and analysis at hazardous waste sites, New York, Marcel Dekker, p. 73-120.

Barber, L.B., II, Thurman, E.M., Schroeder, M.P., and LeBlanc, D.R., 1988, Long-term fate of organic micropollutants in sewage-contaminated groundwater: Environmental Science \& Technology, v. 22, no. 2, p. 205-211.

Böhlke, J.K., and Denver, J.M., 1995, Combined use of groundwater dating, chemical, and isotopic analyses to resolve the history and fate of nitrate contamination in two agricultural watersheds, Atlantic Coastal Plain, Maryland: Water Resources Research, v. 31, no. 9, p. 2319-2339.

Böhlke, J.K., Smith, R.L., and Miller, D.N., 2006, Ammonium transport and reaction in contaminated groundwater-Application of isotope tracers and isotope fractionation factors: Water Resources Research, v. 42, W05411, doi:10.1029/2005WR004349.

Bowen, J.L., Kroeger, K.D., Tomasky, G., Pabich, W.J., Cole, M.L., Carmichael, R.H., and Valiela, I., 2007, A review of land-sea coupling by groundwater discharge of nitrogen to New England estuaries-Mechanisms and effects: Applied Geochemistry, v. 22, p. 175-191.

Bowen, J.L., and Valiela, I., 2001, The ecological effects of urbanization of coastal watersheds - Historical increases in nitrogen loads and eutrophication of Waquoit Bay estuaries: Canadian Journal of Fish and Aquatic Sciences, v. 58, p. 1489-1500.

Ceazan, M.L., Thurman, E.M., and Smith, R.L., 1989, Retardation of ammonium and potassium through a contaminated sand and gravel aquifer-The role of cation exchange: Environmental Science \&Technology, v. 23, no. 11, p. 1402-1408.

Clarke, I., Timlin, R., Bourbonnais, A., Jones, K., LaFleur, D., and Wickens, K., 2008, Origin and fate of industrial ammonium in anoxic ground water $-{ }^{15} \mathrm{~N}$ evidence for anaerobic oxidation (anammox): Ground Water Monitoring and Remediation, v. 28, no. 3, p. 73-82.

Cole, M.L., Kroeger, K.D., McClelland, J.W., and Valiela, I., 2006, Effects of watershed land use on nitrogen concentrations and $\delta^{15}$ nitrogen in groundwater: Biogeochemistry, v. 77, p. 199-215.

DeSimone, L.A., and Howes, B.L., 1998, Nitrogen transport and transformation in a shallow aquifer receiving wastewater discharge-A mass balance approach: Water Resources Research, v. 34, no. 2, p. 271-285. 
Farnsworth, R.K., Thompson, E.S., and Peck, E.L., 1982, Evaporation atlas for the contiguous 48 States: National Oceanic and Atmospheric Administration Technical Report NWS 33, 26 p.

Frimpter, M.H., 1990, A mass-balance nitrate model for predicting the effects of land use on ground-water quality: U.S. Geological Survey Open-File Report 88-493, 17 p.

Garabedian, S.P., LeBlanc, D.R., Gelhar, L.W., and Celia, M.A., 1991, Large-scale natural gradient tracer test in sand and gravel, Cape Cod, Massachusetts-2. Analysis of spatial moments for a nonreactive tracer: Water Resources Research, v. 27, no. 5, p. 911-924.

Harbaugh, A.W., 2005, MODFLOW-2005, the U.S. Geological Survey modular ground-water model-The groundwater flow process: U.S. Geological Survey Techniques and Methods, book 6, chap. A16, variously paged.

Harbaugh, A.W., Banta, E.R., Hill, M.C., and McDonald, M.G., 2000, MODFLOW-2000, The U.S. Geological Survey modular ground-water model-User guide to modularization concepts and the ground-water flow process: U.S. Geological Survey Open-File Report 00-92, 121 p.

Harvey, R.W., and Barber, L.B., II, 1992, Associations of freeliving bacteria and dissolved organic compounds in a plume of contaminated groundwater: Journal of Contaminant Hydrology, no. 9, p. 91-103.

Harvey, R.W., Smith, R.L., and George, L., 1984, Effect of organic contamination upon microbial distributions and heterotrophic uptake in a Cape Cod, Mass., aquifer: Applied and Environmental Microbiology, v. 48, no. 2, p. $1197-1202$.

Howes, B., Ramsey, J.S., Kelley, S.W., Samimy, R., Schlezinger, D., and Eichner, E., 2005, Linked watershed-embayment model to determine critical nitrogen loading thresholds for Great/Perch Pond, Green Pond and Bournes Pond, Falmouth, Massachusetts: Boston, Massachusetts Department of Environmental Protection, Massachusetts Estuaries Project, 205 p.

Jetten, M.S.M., 1999, New pathways for ammonia conversion in soil and aquatic ecosystems: Plant and Soil, v. 230, p. 9-19.

Jetten, M.S.M., Wagner, M., Fuerst, J., van Loosdrecht, M., Kuenen, G., and Stous, M., 2001, Microbiology and application of the anaerobic ammonium oxidation (anammox) process: Current Opinions in Biotechnology, v. 12, p. $283-288$.

Korom, S.F., 1992, Natural denitrification in the saturated zone-A review: Water Resources Research, v. 28, no. 6, p. 1657-1668.
Kroeger, K.D., and Charette, M.A., 2008, Nitrogen biogeochemistry of submarine groundwater discharge: Limnology and Oceanography, v. 53, no. 3, p. 1025-1039.

Kroeger, K.D., Cole, M.L., and Valiela, I., 2006a, Groundwater-transported dissolved organic nitrogen exports from coastal watersheds: Limnology and Oceanography, v. 51, no. 5 , p. 2248-2261.

Kroeger, K.D., Cole, M.L., York, J.K., and Valiela, I., 2006b, Nitrogen loads to estuaries from waste water plumesModeling and isotopic approaches: Ground Water, v. 44, no. 2, p. 188-200.

LeBlanc, D.R., 1984a, Sewage plume in a sand and gravel aquifer, Cape Cod, Massachusetts: U.S. Geological Survey Water-Supply Paper 2218, 28 p.

LeBlanc, D.R., 1984b, Digital modeling of solute transport in a plume of sewage-contaminated ground water, in LeBlanc, D.R., ed., Movement and fate of solutes in a plume of sewage-contaminated ground water, Cape Cod, Massachusetts-U.S. Geological Survey Toxic Waste Ground-Water Contamination Program-Papers presented at the toxic waste technical meeting, Tucson, Arizona, March 20-22, 1984: U.S. Geological Survey Open-File Report 84-475, p. $11-46$.

Massachusetts Office of Geographic Information, 2010, Datalayers and metadata: Massachusetts Office of Geographic Information, accessed 2010 at http://www.state.ma.us./mgis/ massgis.htm.

Masterson, J.P., Carlson, C.S., and Walter, D.A., 2009, Hydrogeology and simulation of groundwater flow in the Plymouth-Carver-Kingston-Duxbury aquifer system, southeastern Massachusetts: U.S. Geological Survey Scientific Investigations Report 2009-5063, 110 p.

Masterson, J.P., Stone, B.D., Walter, D.A., and Savoie, J.G., 1997, Hydrogeologic framework of western Cape Cod, Massachusetts: U.S. Geological Survey Hydrologic Investigations Atlas HA-741, 1 pl., scale 1:50,000.

Masterson, J.P., Walter, D.A., and LeBlanc, D.R., 1998, Delineation of contributing areas to selected public-supply wells, western Cape Cod, Massachusetts: U.S. Geological Survey Water-Resources Investigations Report 98-4237, 45 p.

McCobb, T.D., LeBlanc, D.R., and Hess, K.M., 1999, Determination of temporal and spatial variability of hydraulic gradients in an unconfined aquifer using three-point triangulation, Cape Cod, Massachusetts, in Morganwalp, D.W., and Buxton, H.T., eds., U.S. Geological Survey Toxic Substances Hydrology Program-Proceedings of the technical meeting, Charleston, South Carolina, March 8-12, 1999volume 3-Subsurface contamination from point sources: U.S. Geological Survey Water-Resources Investigations Report 99-4018C, p. 349-360. 
McCobb, T.D., LeBlanc, D.R., Walter, D.A., Hess, K.M., Kent, D.B., and Smith, R.L., 2003, Phosphorus in a groundwater contaminant plume discharging to Ashumet Pond, Cape Cod, Massachusetts, 1999: U.S. Geological Survey Water-Resources Investigations Report 02-4306, 69 p.

McDonald, M.G., and Harbaugh, A.W., 1988, A modular three-dimensional finite-difference ground-water-flow model: U.S. Geological Survey Techniques of WaterResources Investigations, book 6, chap. A1, 586 p.

Miller, D.N., and Smith, R.L., 2009, Microbial characterization of nitrification in a shallow, nitrogen-contaminated aquifer, Cape Cod, Massachusetts and detection of a novel cluster associated with nitrifying Betaproteobacteria: Journal of Contaminant Hydrology, v. 103, p.182-193.

Mulder, A., van de Graaf, A.A., Robertson, L.A., and Kuenen, J.G., 1995, Anaerobic ammonium oxidation discovered in a denitrifying fluidized bed reactor: FEMS Microbiology and Ecology, v. 16, p. 177-184.

Orzol, L.L., 1997, User's guide for MODTOOLS - Computer programs for translating data of MODFLOW and MODPATH into geographic information systems files: U.S. Geological Survey Open-File Report 97-240, 86 p.

Parkhurst, D.L., Stollenwerk, K.G., and Colman, J.A., 2003, Reactive-transport simulation of phosphorus in the sewage plume at the Massachusetts Military Reservation, Cape Cod, Massachusetts: U.S. Geological Survey WaterResources Investigations Report 03-4017, 33 p.

Persky, J.H., 1986, The relation of ground-water quality to housing density, Cape Cod, Massachusetts: U.S. Geological Survey Water-Resources Investigations Report 86-4093, $28 \mathrm{p}$.

Pollock, D.W., 1994, Users' guide for MODPATH/MODPATH-PLOT, version 3-A particle tracking post-processing package for MODFLOW, the U.S. Geological Survey finite-difference ground-water flow model: U.S. Geological Survey Open-File Report 94-464, 234 p.

Prudic, D.E., 1989, Documentation of a computer program to simulate stream-aquifer relations using a modular, finite-difference, ground-water flow model: U.S. Geological Survey Open-File Report 88-729, 113 p.

Repert, D.A., Barber, L.B., Hess, K.M., Keefe, S.H., Kent, D.B., LeBlanc, D.R., and Smith, R.L., 2006, Long-term natural attenuation of carbon and nitrogen within a groundwater plume after removal of the treated wastewater source: Environmental Science \& Technology, v. 40, no. 4, p. $1154-1162$.

Rich, J.J., Dale, O.R., Song, B., and Ward, B.B., 2008, Anaerobic ammonium oxidation (anammox) in Chesapeake Bay sediments: Microbial Ecology, v. 55, p. 311-320.
Robertson, W.D., Moore, T.A., Spoelstra, J., Li, L., Elgood, R.J., Clark, I.D., Schiff, S.L., Aravena, R., and Neufeld, J.D., 2012, Natural attenuation of septic system nitrogen by anammox: Ground Water, v. 50, no. 4, p. 541-553.

Savoie, J.G., and LeBlanc, D.R., eds., 1998, Water-quality data and methods of analysis for samples collected near a plume of sewage-contaminated ground water, Ashumet Valley, Cape Cod, Massachusetts, 1993-94: U.S. Geological Survey Water-Resources Investigations Report 97-4269, $208 \mathrm{p}$.

Savoie, J.G., LeBlanc, D.R., Fairchild, G.M., Smith, R.L., Kent, D.B., Barber, L.B., Repert, D.A., Hart, C.P., Keefe, S.H., and Parsons, L.A., 2012, Groundwater-quality data for a treated-wastewater plume near the Massachusetts Military Reservation, Ashumet Valley, Cape Cod, Massachusetts, 2006-08: U.S. Geological Survey Data Series 648, 11 p., CD-ROM.

Smith, R.L., Baumgartner, L.K., Miller, D.N., Repert, D.A., and Böhlke, J.K., 2006, Assessment of nitrification potential in ground water using short term, single-well injection experiments: Microbial Ecology, v. 51, p. 22-35.

Smith, R.L., Böhlke, J.K., Garabedian, S.P., Révész, K.M., and Yoshinari, T., 2004, Assessing denitrification in groundwater using natural gradient tracer tests with ${ }^{15} \mathrm{~N}$ - In situ measurement of a sequential multistep reaction: Water Resources Research, v. 40, W07101, doi:1029/2003WR002919.

Smith, R.L., and Duff, J.H., 1988, Denitrification in a sand and gravel aquifer: Applied and Environmental Microbiology, v. 52, no. 5, p. 1071-1078.

Smith, R.L., Garabedian, S.P., and Brooks, M.H., 1996, Comparison of denitrification activity measurements in groundwater using cores and natural-gradient tracer tests: Environmental Science \& Technology, v. 30, no. 12, p. 3448-3456.

Smith, R.L., Howes, B.L., and Duff, J.H., 1991, Denitrification in nitrate-contaminated groundwater-Occurrence in steep vertical geochemical gradients: Geochimica et Cosmochimica Acta, v. 55, p. 1815-1825.

Sudicky, E.A., 1986, A natural gradient experiment on solute transport in a sand aquifer-Spatial variability of hydraulic conductivity and its role in the dispersion process: Water Resources Research, v. 22, no. 13, p. 2069-2082.

Thurman, E.M., Barber, L.B., II, and LeBlanc, D., 1986, Movement and fate of detergents in groundwater- $\mathrm{A}$ field study: Journal of Contaminant Hydrology, no. 1, p. 143-161. 
Walter, D.A., 2007, Use of numerical models to simulate transport of sewage-derived nitrate in a coastal aquifer, Central and Western Cape Cod, Massachusetts: U.S. Geological Survey Scientific Investigations Report 2007-5259, 41 p.

Walter, D.A., 2013, The effect of wastewater management actions on the hydrologic system and nitrogen loading rates to well and ecological receptors, Popponesset Bay watershed, Cape Cod, Massachusetts: U.S. Geological Survey Scientific Investigations Report 2013-5060, In press

Walter, D.A., and Masterson, J.P., 2003, Simulation of advective flow under steady-state and transient recharge conditions, Camp Edwards, Massachusetts Military Reservation, Cape Cod, Massachusetts: U.S. Geological Survey WaterResources Investigations Report 03-4053, 51 p.

Walter, D.A., Masterson, J.P., and LeBlanc, D.R., 2002, Simulated pond-aquifer interactions under natural and stressed conditions near Snake Pond, Cape Cod, Massachusetts: U.S. Geological Survey Water-Resources Investigations Report 99-4174, $35 \mathrm{p}$.

Walter, D.A., and Whealan, A.T., 2005, Simulated water sources and effects of pumping on surface and ground water, Sagamore and Monomoy flow lenses, Cape Cod, Massachusetts: U.S. Geological Survey Water-Resources Investigations Report 2004-5181, 85 p. 
THIS PAGE INTENTIONALLY LEFT BLANK 
Prepared by the Pembroke Publishing Service Center.

For more information concerning this report, contact:

Director

U.S. Geological Survey

New England Water Science Center

Massachusetts-Rhode Island Office

10 Bearfoot Road

Northborough, MA 01532

dc_ma@usgs.gov

or visit our Web site at:

http://ma.water.usgs.gov 
